\title{
Effect of Reforestation
}

on Streamflow in

Central New York

GEOLOGICAL SURVEY WATER-SUPPLY PAPER 1602

Prepared in cooperation with the New York State Department of Conservation Division of Lands and Forests

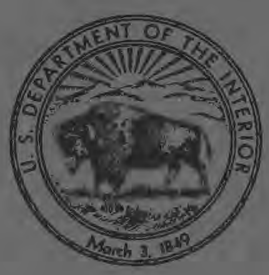




\section{Effect of Reforestation}

on Streamflow in

Central New York

By WILLIAM J. SCHNEIDER and GORDON R. AYER

GEOLOGICAL SURVEY WATER-SUPPLY PAPER 1602

Prepared in cooperation with the New York State Department of Conservation Division of Lands and Forests

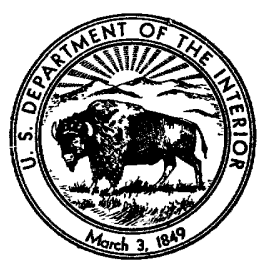




\title{
UNITED STATES DEPARTMENT OF THE INTERIOR
}

STEWART L. UDALL, Secretary

\author{
GEOLOGIGAL SURVEY
}

Thomas B. Nolan, Director 


\section{CONTENTS}

Page

Abstract...

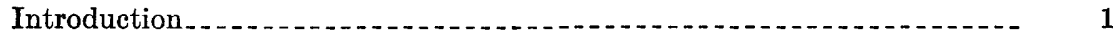

History of project.

Purpose and scope of present analysis . . . 2

Acknowledgments .

Description of areas

Location . . .

Climate. . . 3

Physiography ........... 4

Geology and soils

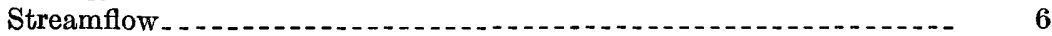

Characteristics of the specific basins _.

Sage Brook area

Cold Spring Brook area.

Shackham Brook area._._._.

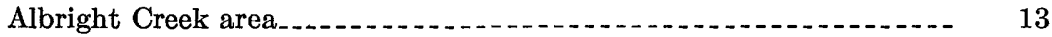

Reforestation of the study areas...

Records available.......... 30

Streamflow

Precipitation

Hydrologic analyses............... 31

Reliability of data

Streamflow data

Precipitation data............ 32

Determination of precipitation indexes...... 35

Relation between runoff and precipitation........ 36

Correlation analysis._.

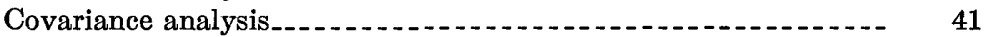

Relation between runoff from reforested area and from control area_- 42

Seasonal and annual runoff . . . .

Peak discharges. . .

Low flows........... 51

Other analyses....... 52

Base-flow recession . .

Relation between volumes of direct runoff and precipitation from individual storms......... 53

Methods rejected..... 54

Summary.............. 56

Evaluation of the study

References cited.... 60

\section{ILLUSTRATIONS}

Figure 1. Location of streamflow areas

2. Monthly distribution of precipitation for Shackham Brook area, 1935-57.

3. Monthly distribution of runoff from Shackham Brook area, 1934-57 
Frgure 4. Hydrograph for Shackham Brook near Truxton, 1948_-.---

5. Topography and location of instruments in Sage Brook area.-

6. Soils in Sage Brook area

7. Topography and location of instruments in Cold Spring Brook area.

8. Soils in Cold Spring Brook area

9. Topography and location of instruments in Shackham Brook area

10. Soils in Shackham Brook area

11. Topography and location of instruments in Albright Creek area.

12. Soils in Albright Creek area

13. Reforestation in Sage Brook area.......

14. Reforestation in Cold Spring Brook area

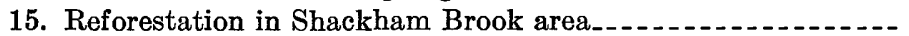

16. Types of plant cover in Sage Brook area

17. Types of plant cover in Cold Spring Brook area.........

18. Types of plant cover in Shackham Brook area..........

19. Types of plant cover in Albright Creek area, 1948.....

20. Percentage of crown cover in Sage Brook area, 1948......-

21. Percentage of crown cover in Cold Spring Brook area......-

22. Percentage of crown cover in Shackham Brook area.......-

23. Relation between precipitation gages 1 and 2 for Shackham Brook area.

24. Relation between cumulative precipitation for gages in study areas and cumulative areal index of precipitation

25. Annual precipitation recorded by gage 1 in the Shackham Brook area, 1934-57.

26. Relation between runoff and precipitation in the Cold Spring Brook area for the 6-month period ending April 30, showing the change with time.

27. Relation between runoff from Shackham Brook area and Albright Creek area for the 6-month period ending April 30, showing the change with time

28. Relation between runoff from Shackham Brook area and Albright Creek area for the 6-month period ending October 31 , showing the change with time

29. Relation between runoff from Shackham Brook area and Albright Creek area for the 12-month period ending April 30, showing the change with time

30. Relation between peak flows of Shackham Brook and Albright Creek for the 6-month period ending April 30..........

31. Effect of date of occurrence on relation between peak discharges of Shackham Brook and Albright Creek .........-

32. Effect of date of occurrence on relation between peak discharges of Shackham Brook and Albright Creek

33. Base-flow recession rates for Cold Spring Brook at China

34. Relation between storm precipitation and volumes of direct runoff for Sage Brook area....... 


\section{TABLES}

TABLE 1. Types of cover in study areas.

2. Crown cover in reforested areas

3. List of species planted in reforestation program

4. Reforestation in Sage Brook area

5. Reforestation in Cold Spring Brook area

6. Reforestation in Shackham Brook area

7. Precipitation and runoff totals for selected hydrologic periods - $\quad 37$

8. Relation of runoff to precipitation

9. Related peak discharges on Shackham Brook and on Albright

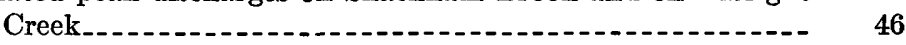

10. Annual low flows for Shackham Brook and Albright Creek areas.-.-.-.-.

11. Coefficients of base-flow recession 


\title{
EFFECT OF REFORESTATION ON STREAMFLOW IN GENTRAL NEW YORK
}

\author{
By William J. Schneider and Gordon R. Ayer
}

\begin{abstract}
Hydrologic data have been collected since 1932 in central New York State to determine the effect of reforestation on streamflow. Data are available for three small partly reforested areas and for one nonreforested control area. From $\mathbf{3 5}$ to 58 percent of the 3 areas were reforested, mostly with species of pine and spruce. The trees were allowed to grow without thinning or cutting, and by 1958 these reforested areas had developed into dense coniferous woodlots.

Intensive statistical analyses of the data from the four study areas were made in 1958. Analyses were made for three hydrologic periods: the dormant season represented by the 6-month period ending April 30, the growing season represented by the 6-month period ending October 31, and the year represented by the 12month period ending April 30. Analyses of the hydrologic data using multiplecorrelation with time as a variable and analyses of covariance between early and late periods of record indicated that several significant changes had occurred in the streamflow from the partly reforested study areas. Based on correlation with precipitation, total runoff for the dormant season from the 3 study areas was reduced by annual rates of 0.17 to 0.29 inches per year. Based on correlations with streamflow from a control area, total runoff from the partly reforested Shackham Brook area was reduced by average rates of 0.14 inches per growing season, 0.23 inches per dormant season, and 0.36 inches per hydrologic year. Peak discharges on Shackham Brook during the dormant season were reduced by 1958 by an average of 41 percent for the season, with reductions ranging from an average of 66 percent for November to an average of 16 percent for April. No significant changes were found in the peak discharges for the growing season, rates of base-flow recession, volumes of direct runoff, or annual low flows of streams in the three partly reforested areas.

The significant reductions in total runoff are attributed to increases in interception and transpiration in the reforested areas. The reductions in peak discharges during the dormant period are attributed largely to increased interception and sublimation of snowfall, and a gradual desynchronization of snowmelt runoff from the wooded and open areas of partly reforested watersheds. The changes in streamflow occurred gradually over the years; it could not be determined from the data whether changes in streamflow were still occurring in 1958, or whether they had reached a maximum.
\end{abstract}

\section{INTRODUCTION}

During the latter part of the 19th century, many farmers migrated westward from central New York. This migration, coupled with low crop yields from depleted soils and a general abandonment of marginal farmlands, resulted in a decrease in farmland in the State of about 5 million acres between 1880 and 1930. The abandoned farmland soon acquired a heavy cover of weeds and brush.

Chapter 195 of the Laws of 1929 enacted by the New York State Legislature authorized the State Conservation Department to acquire 
parcels of this abandoned or marginal farmland for the perpetual planting, growing, and harvesting of trees. Within 5 years, the State Conservation Department had acquired and reforested more than 340,000 acres in 33 counties of the State. In 1932, the U.S. Geological Survey, in cooperation with the New York State Conservation Department, initiated a project to determine the effect of this reforestation on streamflow.

\section{HISTORY OF THE PROJECT}

Collection of hydrologic data was begun in 1932 with the establishment of facilities to medsure streamflow and precipitation in the Shackham Brook watershed and in the Sage Brook watershed. Parts of these watersheds were reforested in 1931 and 1932 . In 1935 the data-collecting program was expanded to include the Cold Spring Brook watershed which had been reforested the previous year. In 1938 the data collecting program was again expanded to include installations in the Albright Creek watershed, an area in which land-use practices were undergoing little if any changes. Information collected on Albright Creek would be used to measure the rate and extent of any changes defined by the data for the Shackham Brook area.

The project was designed to detect possible changes in streamflow regimen that might occur over a period of years as a result of the growth of the trees by (a) determining changes in the relation of the streamflow to precipitation and other causative factors, and (b) determining changes in the relation between streamflow from a reforested area and streamflow from a nonreforested area.

Several previous reports have been prepared on various phases of the project. Cross ${ }^{1}$ listed and evaluated many hydrologic factors affecting streamflow and outlined a comprehensive program for the measurement of these fectors. A progress report was prepared by Ayer (1949) which analyzed the relations between rainfall and runoff for the study areas. Outlaw (1953) investigated the geology and hydrology of the Shackham Brook watershed, and Barkow ${ }^{2}$ analyzed the streamflow data of the Sage Brook area.

\section{PURPOSE AND SCOPE OF PRESENT ANALYSIS}

An intensive analysis of the hydrologic data collected thus far was begun in 1958. For almost a quarter of a century, data on streamflow and precipitation were collected in four study areas while the trees in the reforested portions of these areas were permitted to grow without

1 Cross, W. P., 1935, A program for the investigation of the influence of forests on streamflow in the State of New York: Columbus, Ohio, Ohio State Univ., unpublished thesis.

Barkow, David, 1957, A study of the effects of reforestation on streamfiow in the Sage Brook watershed near South New Berlin, New York: Ithaca, N.Y., Cornell Univ., unpublished thesis. 
cutting or thinning. The analysis was undertaken as a logical and perhaps final step in the investigation. Because sufficient years of record were available for reliable hydrologic analyses, and because some form of management of the state-owned acreage in the watersheds is likely in the near future, the present analysis was deemed advisable. This report describes the results and conclusions of the analysis.

\section{ACKNOWLEDGMENTS}

This report was prepared on basis of data collected over a period of years in cooperation with the New York State Department of Conservation, Division of Lands and Forests.

Data on reforestation were furnished by the State Division of Lands and Forests, C. D. Kingsbury, superintendent. The cover surveys of the reforested areas were made by personnel of the Division under the supervision of Charles F. Baker, R. Milton Hick, and James D. Kennedy, district foresters.

H. C. Riggs, hydraulic engineer, U.S. Geological Survey, provided valuable assistance in the statistical analysis of the data and in reviewing the manuscript. Dr. Harold G. Wilm, associate dean, College of Forestry, University of the State of New York, at Syracuse, reviewed an early draft of the manuscript and offered many helpful comments and suggestions.

\section{DESCRIPTION OF AREAS}

\section{LOCATION}

The geographic location of the four streamflow areas is shown in figure 1. The Sage Brook area is located east of Norwich in Chenango County. The Cold Spring Brook area is located in Delaware County, south of the Sage Brook area, and just east of the line between Broome County and Delaware County. The Shackham Brook area and Albright Creek area lie to the northwest of the areas previously described. The Albright Creek area lies entirely within Cortland County, while the Shackham Brook area lies in both Cortland County and Onondaga County.

\section{CIIMATE}

The four areas of this study all lie within a climatic region characterized by a continental type of climate. The mean temperature for July is about $66^{\circ} \mathrm{F}$, with maximum temperatures during the summer months often exceeding $90^{\circ} \mathrm{F}$. Winters are severe; the mean temperature for January is about $22^{\circ} \mathrm{F}$, and minimum temperatures below $-30^{\circ} \mathrm{F}$ have been recorded. The average growing season is about 150 days, extending from early May until late September. The seasonal transitions in temperature usually occur during late April and October. 


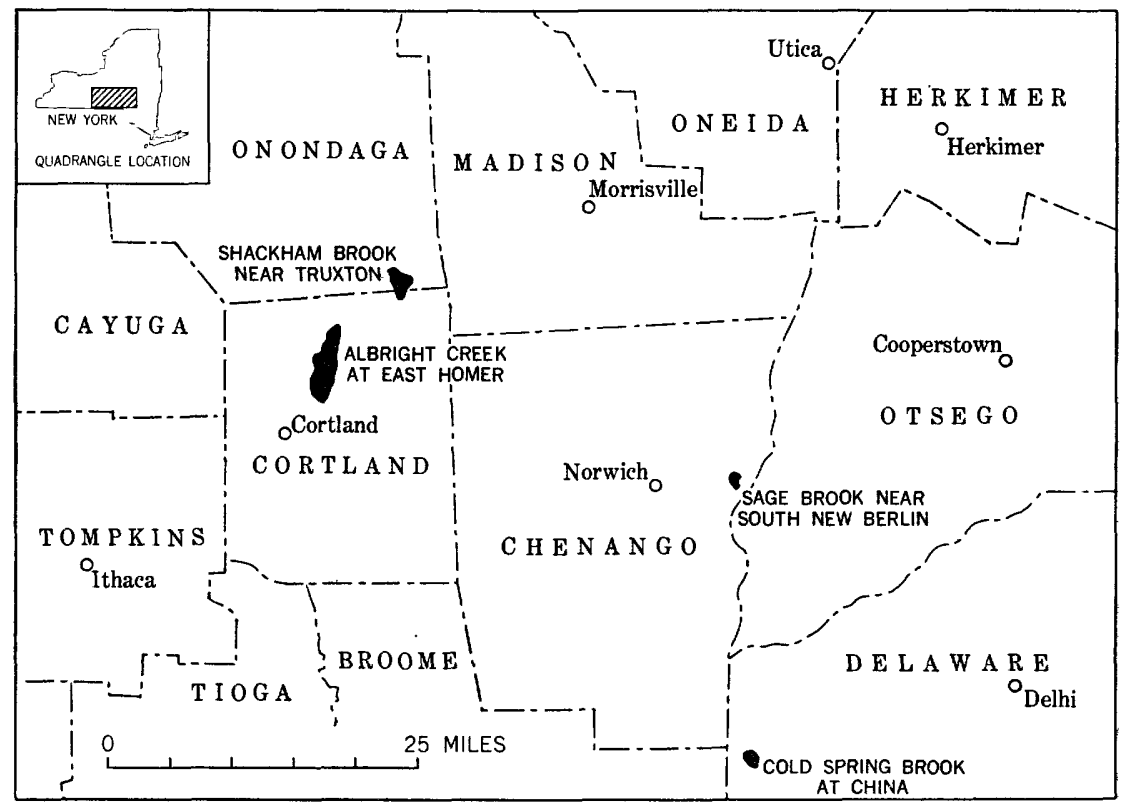

FiGURE 1.-Location of streamflow areas.

Precipitation over the region is from windborne moisture transported from the Gulf of Mexico and the Atlantic Ocean by the action of cyclonic storms. Winter precipitation usually results from general storms associated with frontal activities and occurs chiefly as snow. Mean annual snowfall for the general vicinity of the four streamflow areas is about 60 to 70 inches; however, local topographic features produce significant variations from this average. Summer precipitation generally occurs during thunderstorms; it is frequently very intense, of short duration, and very localized. The precipitation is distributed fairly uniformly throughout the year, as shown in figure 2.

\section{PHYSIOGRAPHY}

Physiographically the four areas are in the Appalachian Plateaus province, which lies along the western base of the mountains. The plateau is here bounded on the east by the Catskill Mountains and on the north by the Helderburg escarpment. Although well dissected by streams, the area is not mountainous. Elevations range from 500 to 600 feet on the northern side of the province to more than 2,000 feet on the eastern and western sides. The four streamflow areas considered in this report all show relief typical of the plateau. 


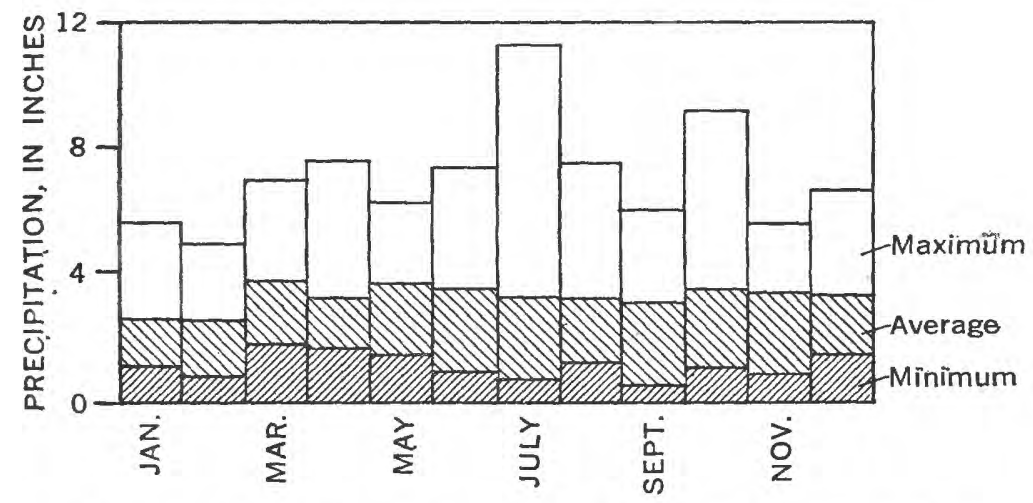

FIGURR 2,-Monthly distribution of precipitation for Shackham Brook area, 1935-37.

\section{GEOLOGY AND SOILS}

The geology of the four areas studied in this report is generally similar. All are underlain by rocks of unaltered sediments of Devonian age, consisting principally of shales and sandstones. The bedrock is overlain by Pleistocene deposits of glacial tills ranging in depth from less than 2 feet to several hundred feet. However, depths in the four areas considered in this report range generally from 2 to 10 feet, with occasional depths of as much as 30 feet in the valleys.

The soils of the four areas consist mainly of glacial tills which have been weathered at the surface. They are typical gray-brown podsolic soils and may be described as follows (Marbut, 1935):

The upper horizon, usually 1 to 4 inches thick, is composed of forest litter and mulch. This is underlain by the $A$ horizon of about 5 to 10 inches of grayish-brown, silty or sandy loam, commonly friable because of the infiltration of humus. Under this is the B horizon of generally less than 15 inches of illuviated soil containing much more clay and having much sparser root penetration than the $\mathrm{A}$ horizon. Unweathered glacial till, usually called the $C$ horizon, occurs between the bottom of the B horizon and the surface of the bedrock.

Ground-water movement occurs and storage exists in both the glacial till and the bedrock. Although the nature of the bedrock permits little penetration of ground water, some movement and storage does occur in the joints, cracks, and bedding planes. These quantities are very small. The friable upper layers of soil have high infiltration capacities, but the relative impermeability of the lower layers of compacted clay causes perched water tables in many places and produces a complicated ground-water pattern. This general 
description of ground-water conditions is based on unpublished data by M. L. Brashears, Jr., U.S. Geological Survey.

\section{STREAMFLOW}

The pattern of streamflow in central New York represents the integrated effect of the climatological and physical characteristics of the area. Streams in the area show the typical annual cycle of high runoff in the spring and seasonal low flows in the fall. The magnitude of the annual cycle is indicated in figure 3. Most streams in the area also reflect a rapid response to rainfall, particularly the smaller ones which show sharp rises in flow during periods of heavy rainfall. A typical hydrograph reflecting this response to rainfall is shown in figure 4.

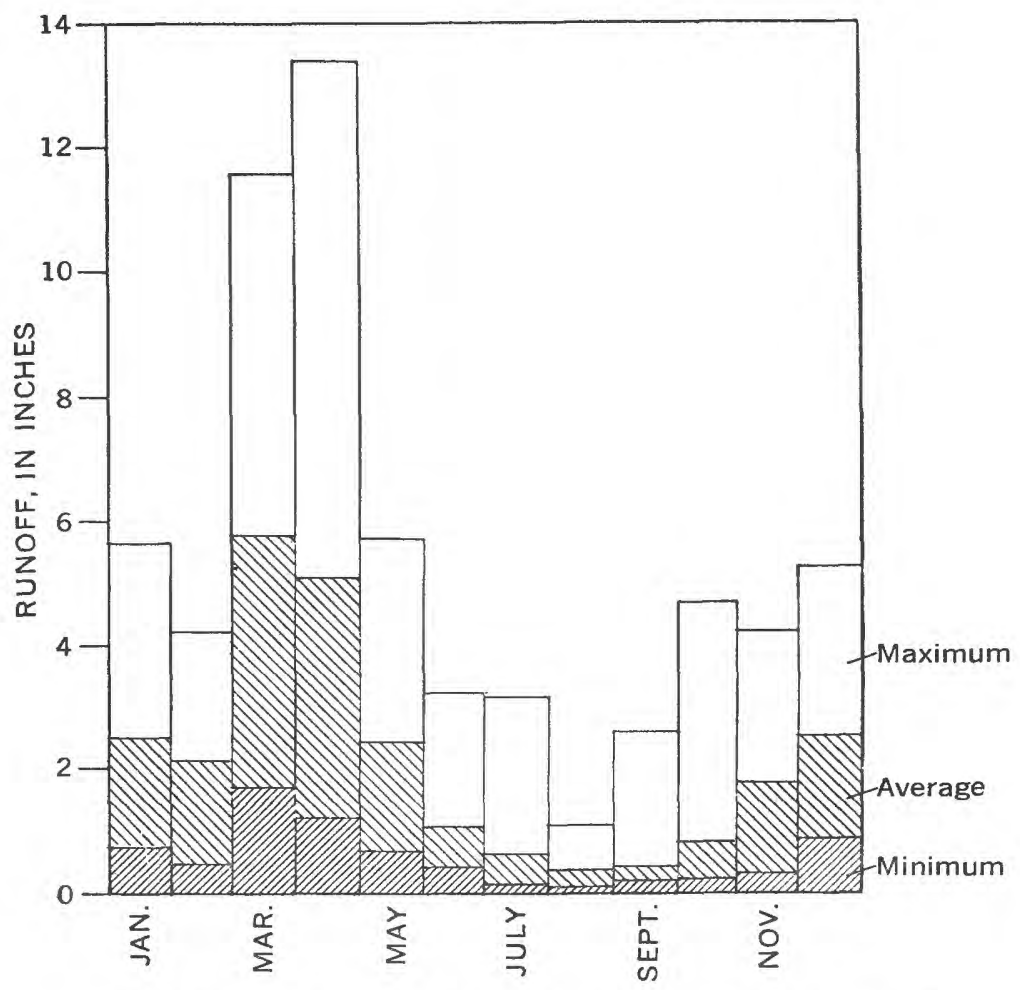

Figure 3.-Monthly distribution of runoff from Shackham Brook area, 1934-57. 


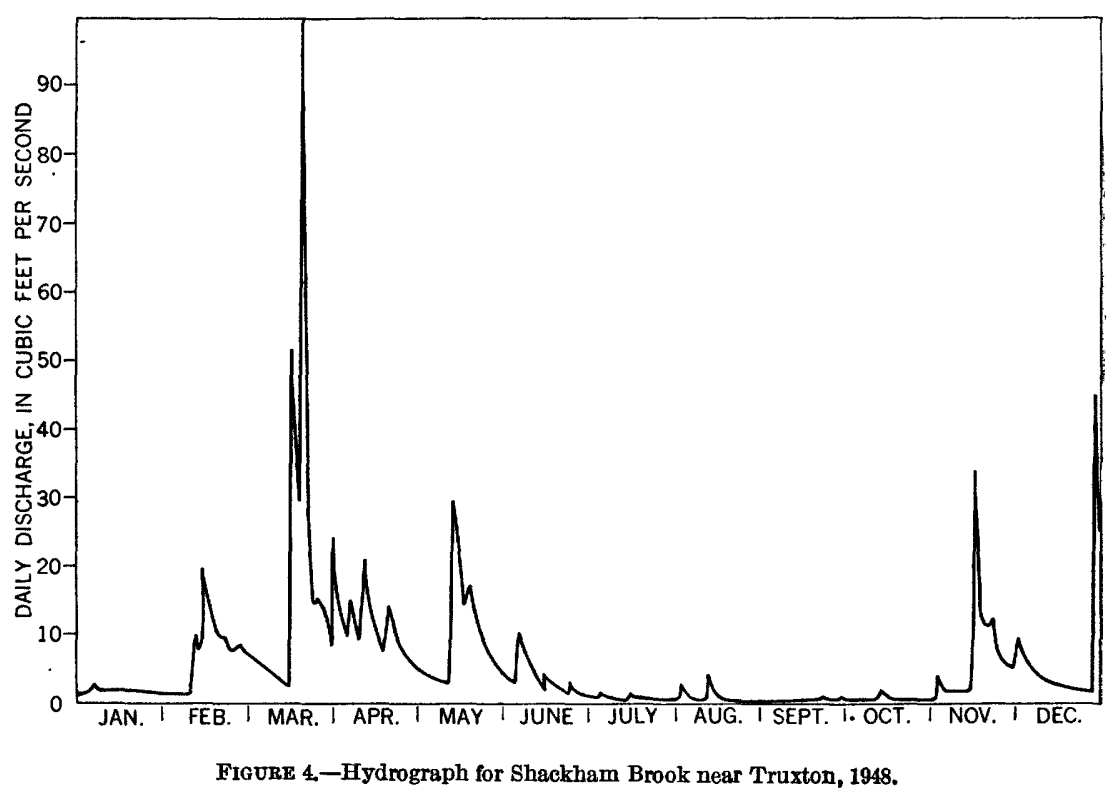

\section{CHARACTERISTICS OF THE SPECIFIC BASINS}

SAGE BROOK AREA

Sage Brook at South New Berlin, N.Y., drains 0.70 square mile. It flows in a southeasterly direction. The main stream is 0.57 mile long. Including the major tributary, the basin has a stream density of 1.00 mile per square mile. Average channel slope of the main stream and tributary is 258 feet per mile.

The basin is somewhat rectangular in shape with well-defined relief. Elevations range from 1,430 feet at the stream-gaging station to 1,940 feet in the northeastern corner of the area. The topography is shown in figure 5. Outcrops of sandstone occur in the northern part of the basin and shale in the southern part. The soil over most of the area is composed of Oquaga silt loam. This loam is generally shallow and well drained. Complete descriptions of the soils are given in Soil Survey of Tioga County (U.S. Dept. Agriculture, 1920). The distribution of the soil types in the basin is shown in figure 6 .

\section{COLD SPRING BROOK AREA}

Cold Spring Brook at China, N.Y., drains 1.51 square miles. It flows in a southerly direction. The main stream is 1.75 miles long. Including the major tributaries, the basin has a stream density of 2.09 miles per square mile. The average channel slope of the main stream and tributaries is 269 feet per mile. 


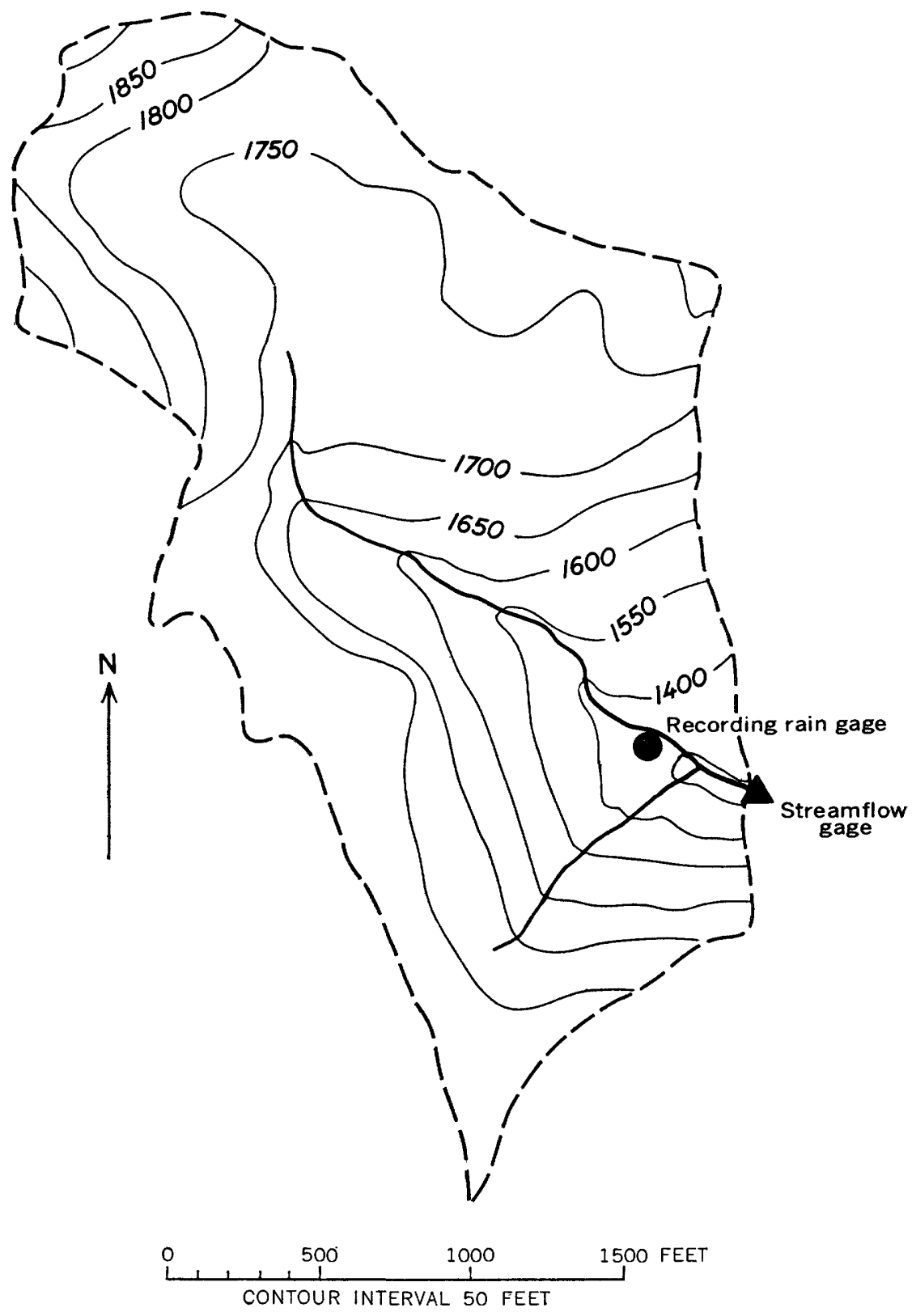

Figdre 5.-Topography and locations of instruments in Sage Brook area. 


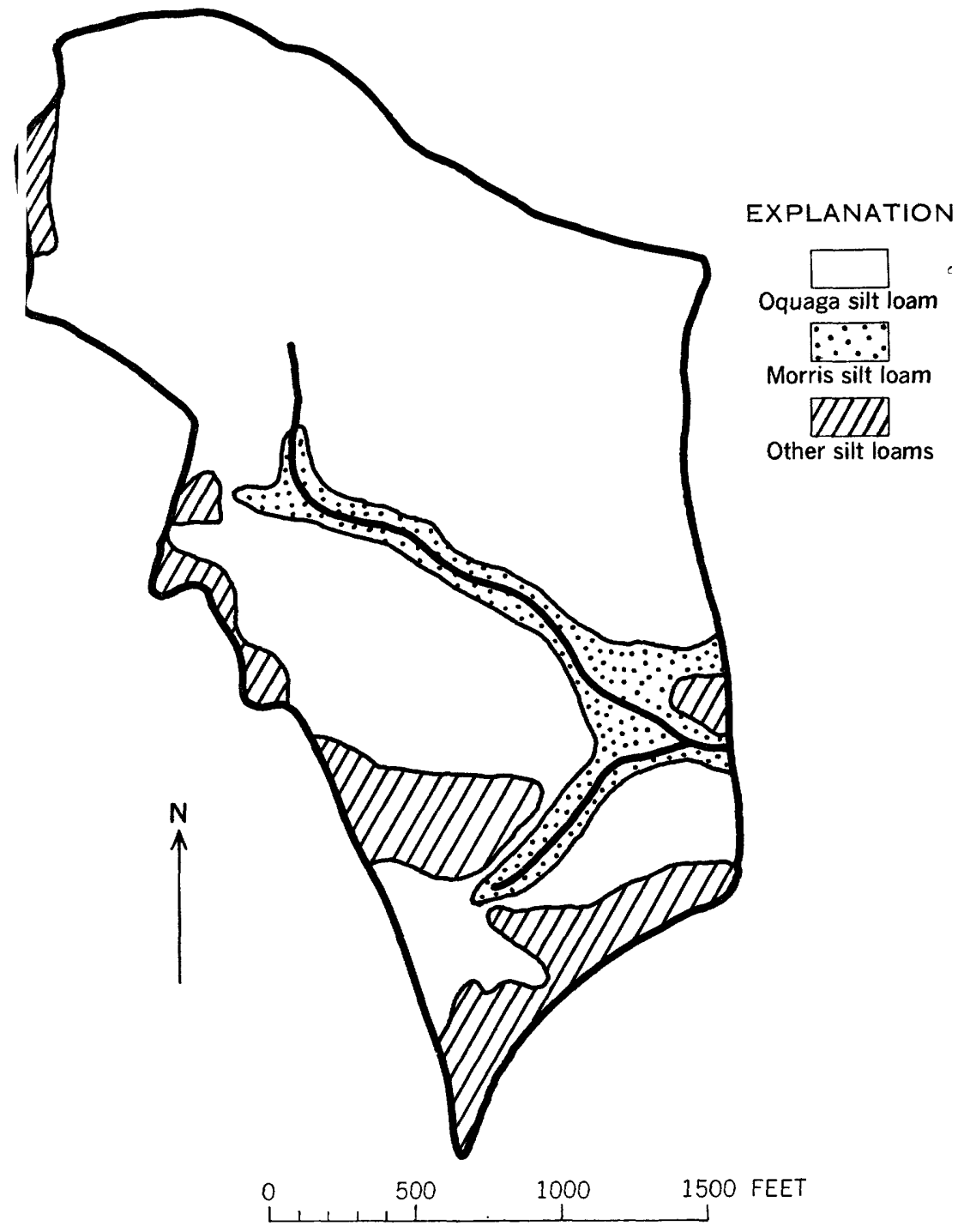

Figure 6.-Solls in Sage Brook area. 
The basin is approximately circular in shape, with well-defined relief. Elevations range from about 1,480 feet at the stream-gaging station to about 2,180 feet at the northern edge of the basin. The steepest slopes occur in the southern or downstream part of the basin. The topography is shown in figure 7. Outcrops of sandstone occur mainly along the ridges and upper slopes. The soils consist of Lordstown and Canfield silt loams and are described in Soil Survey of Delaware County (U.S. Dept. Agriculture, 1930). In some local areas, surface drainage is impeded by small sags and depressions. The distribution of the soil types in the basin is shown in figure 8.

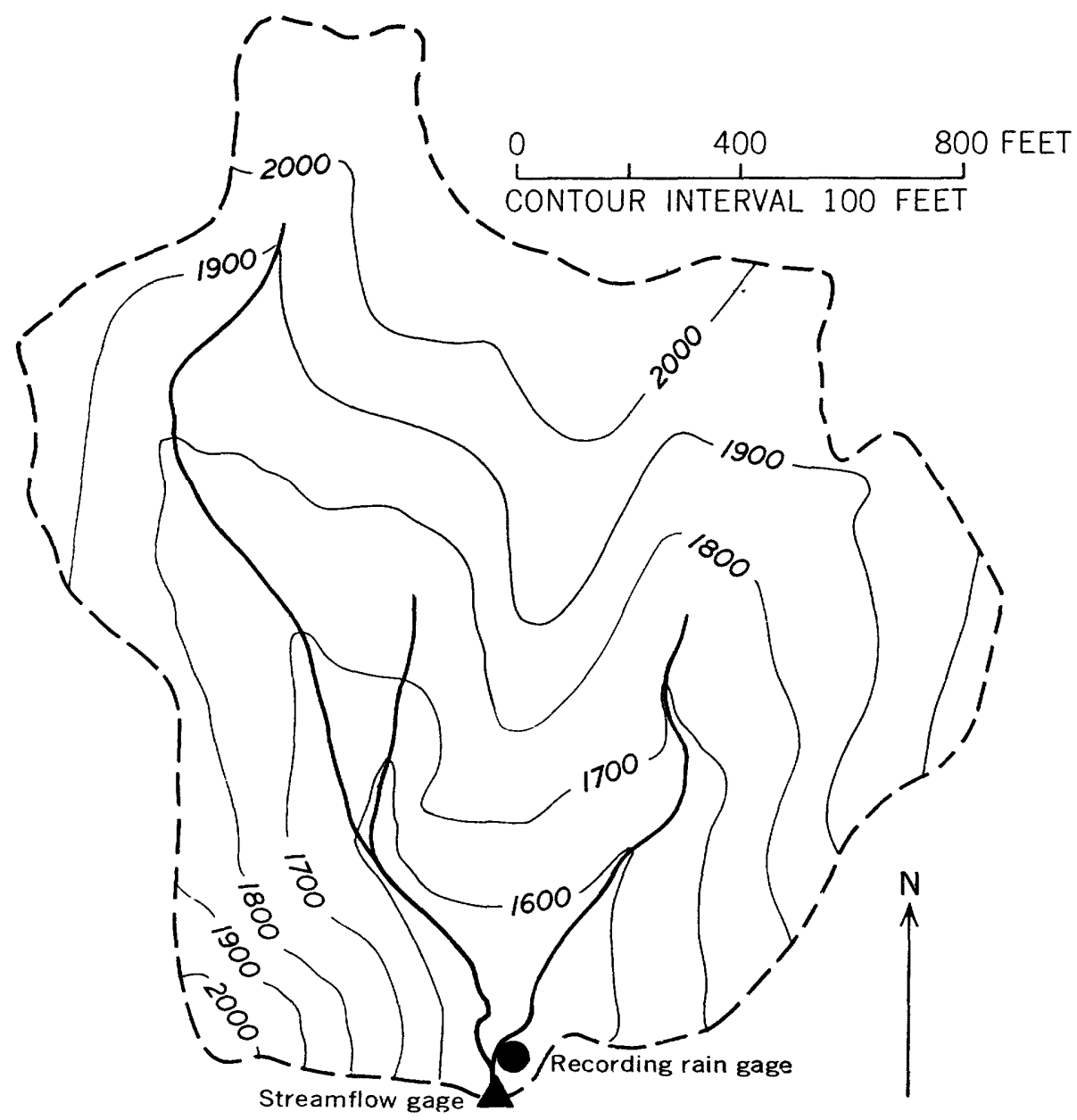

Figure 7.-Topography and location of instruments in Cold spring Brook area. 


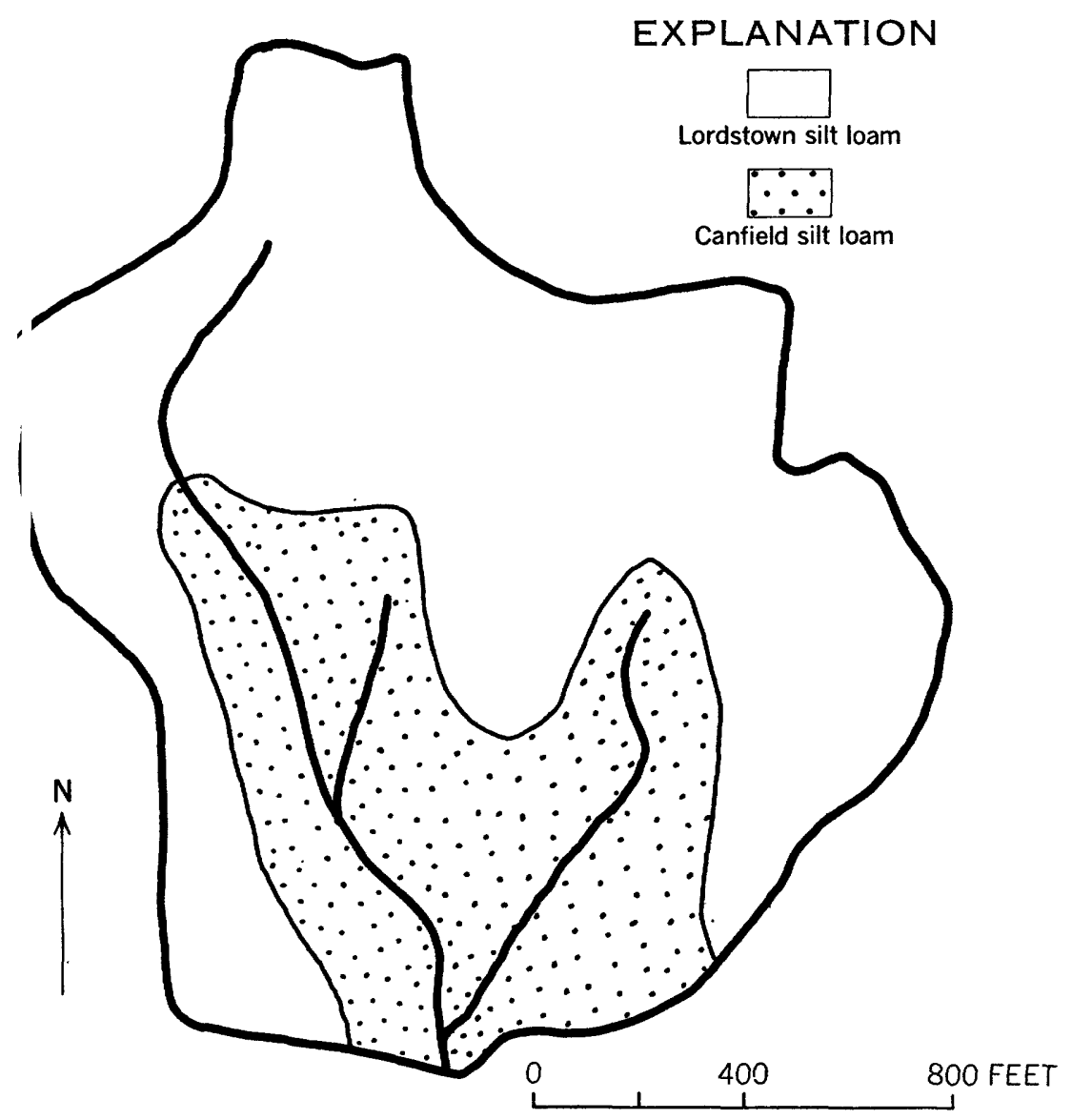

FIGURE 8.-Soils in Cold Spring Brook area.

\section{SHACKHAM BROOK AREA}

Shackham Brook near Truxton, N.Y., drains 3.12 square miles. The main stream is 2.50 miles long. Including the principal tributaries, the basin has a stream density of 1.47 miles per square mile. Average channel slope of the main stream and tributaries is 156 feet per mile.

The basin is somewhat irregular in shape, with well-defined relief. Elevations range from about 1,290 feet at the stream-gaging station to slightly more than 2,000 feet on the eastern ridges. Land slopes are steepest in the southern parts of the basin, and some of the tributaries in this area flow on bedrock channels from an elevation of about 1,600 feet down to their confluences with the brook. The topography is shown in figure 9. The soils are mainly Lordstown, 


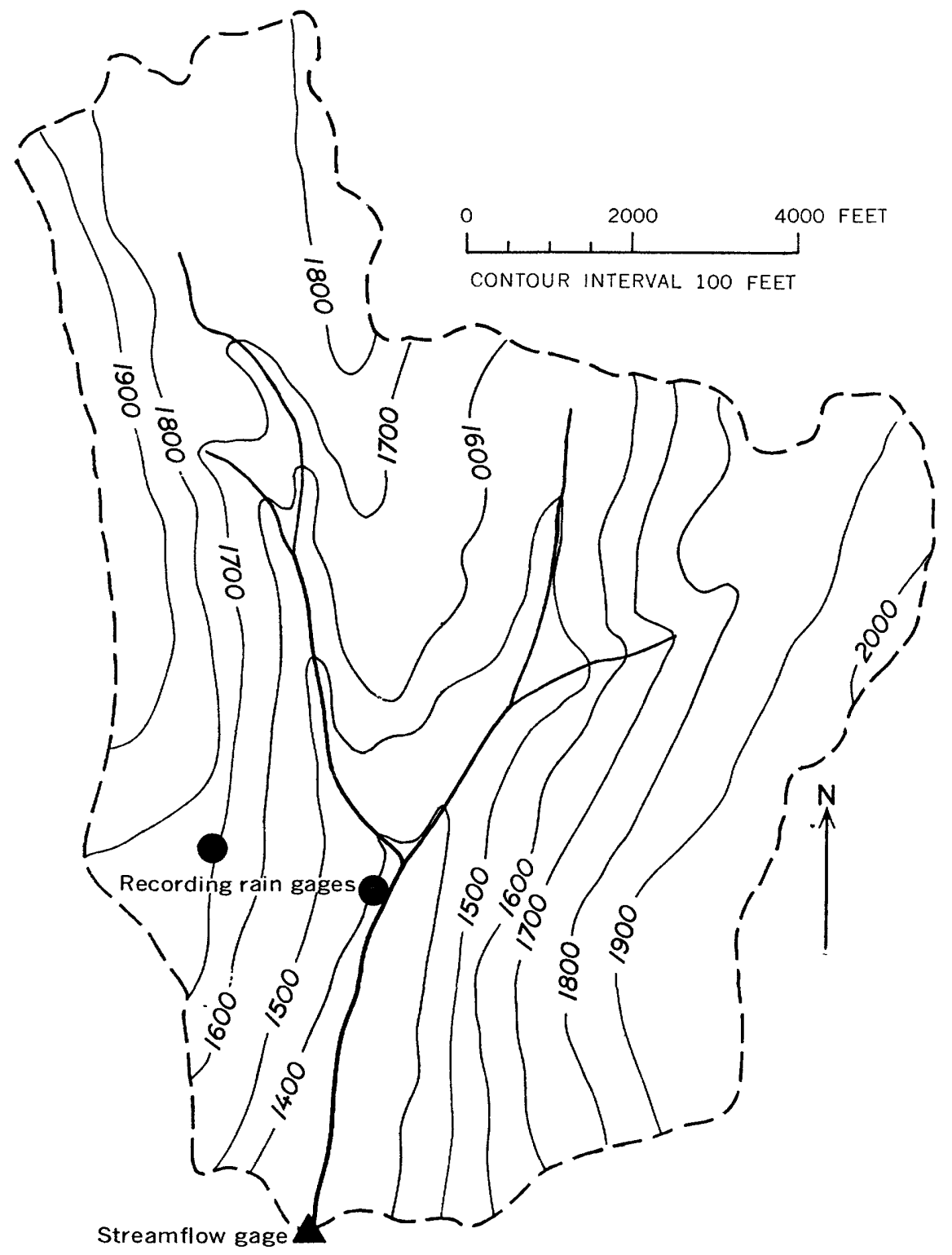

Figure 9.-Topography and location of instruments in Shackham Brook area.

Volusia, and Manlius silt loams. Drainage in the Volusia and Manlius loams is impeded by compacted clay layers, causing perched water tables and hillside seeps. Several minor swampy areas exist in the extreme headwaters of the brook. The soils are described in Soil Survey of Tioga County (U.S. Dept. Agriculture, 1939-53). The distribution of the soil types in the basin is shown in figure 10. 


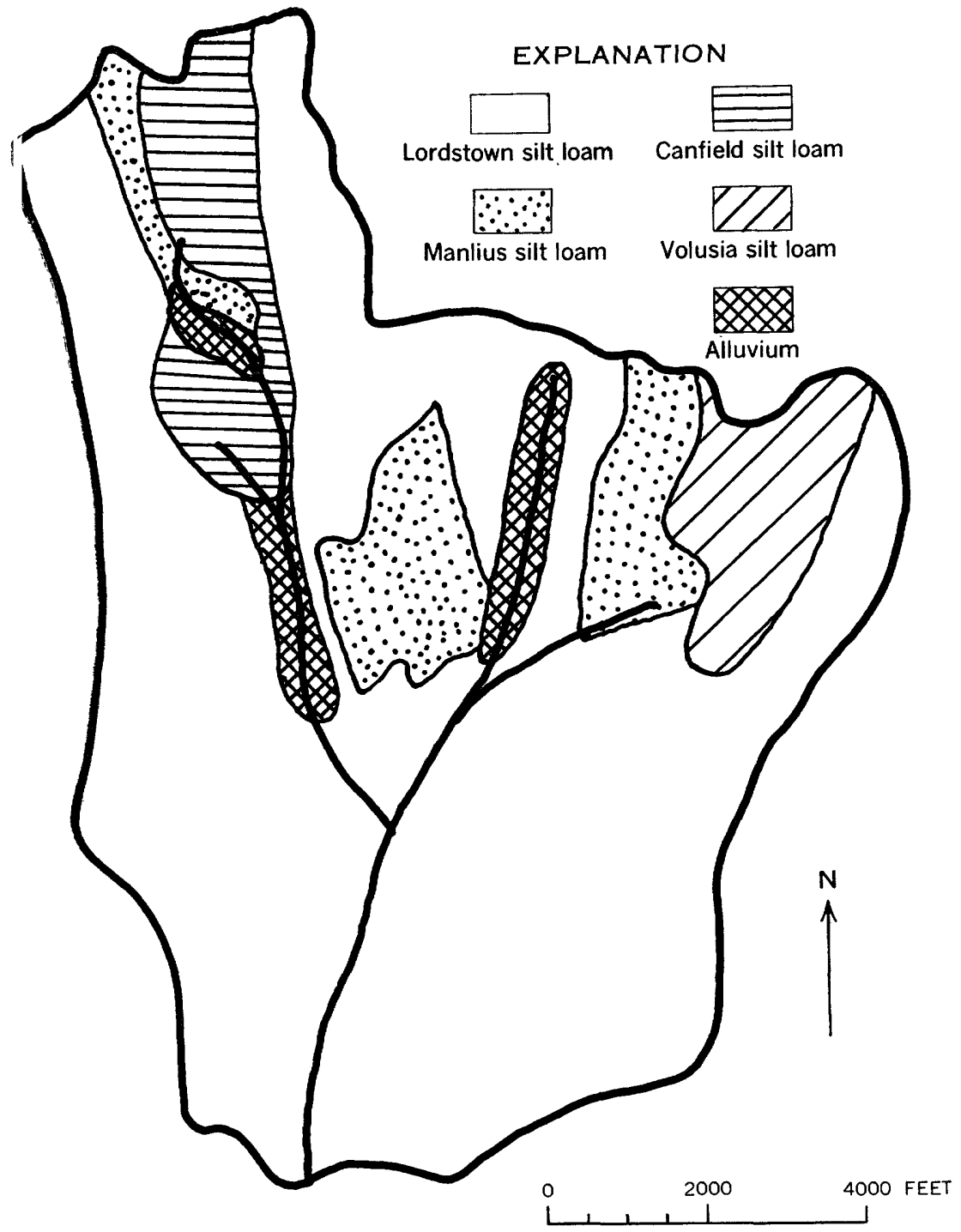

FIGURE 10.-Soils in Shackham Brook area.

\section{ALBRIGHT CREEK AREA}

Albright Creek at East Homer, N.Y., drains 7.08 square miles. It flows in a southerly direction. The main stream is 5.45 miles long. Including the principal tributaries, the basin has a stream density of 1.56 miles per square mile. Average channel slope of the main stream and tributaries is 108 feet per mile. 
The basin is long and relatively marrow with,well-defined relief. Elevations range from about 1,155 feet at the stream-gaging station to about 2,020 feet in the upper end of the basin. The topography is shown in figure 11. Soils in the basin consist of Lordstown and

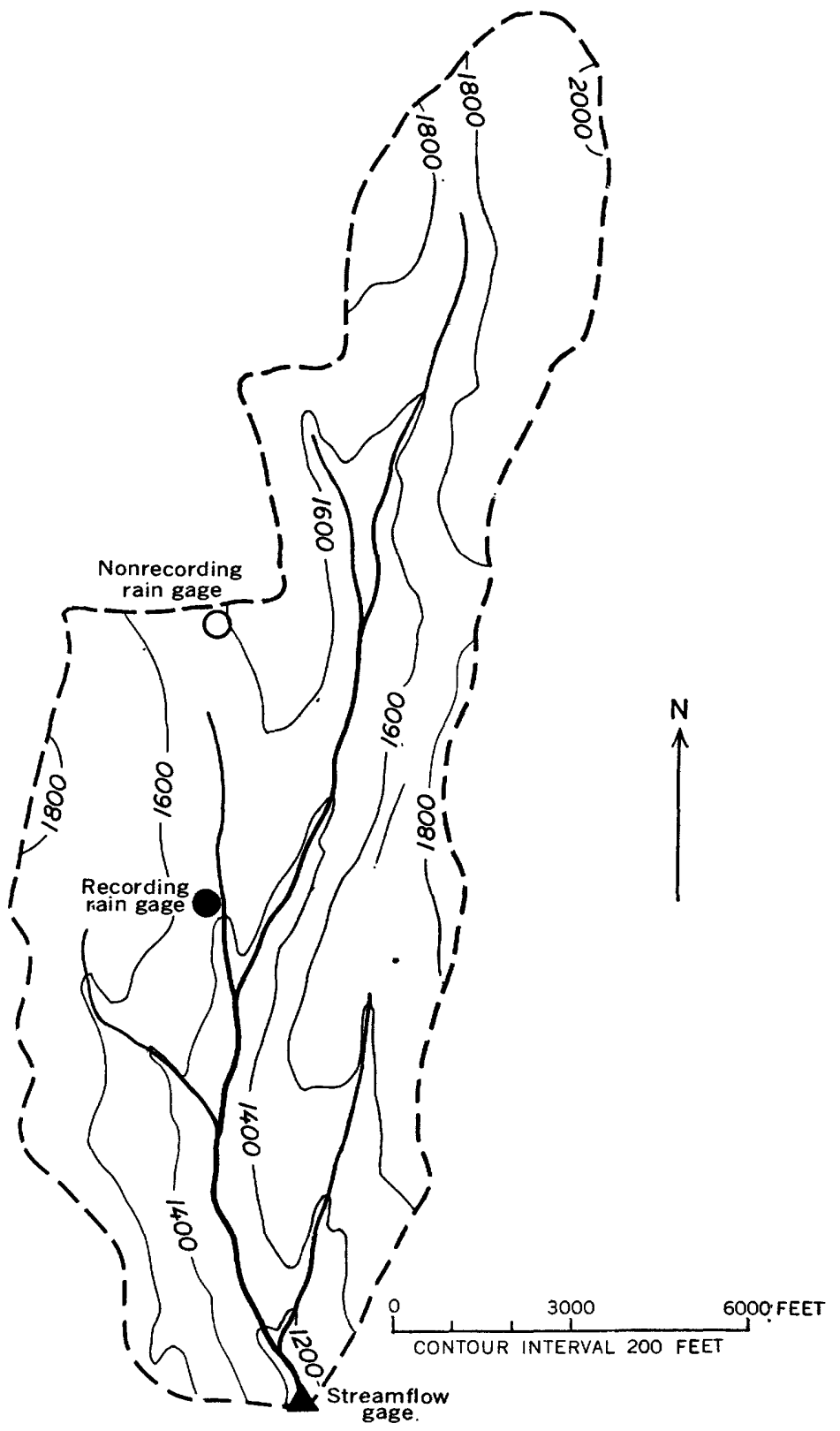

FiguRe 11.-Topography and location of instruments in Albright Creek area. 
Volusia silt loams, similar in characteristics to those in the Shackham Brook area. The distribution of the soil types in the basin is shown in figure 12.

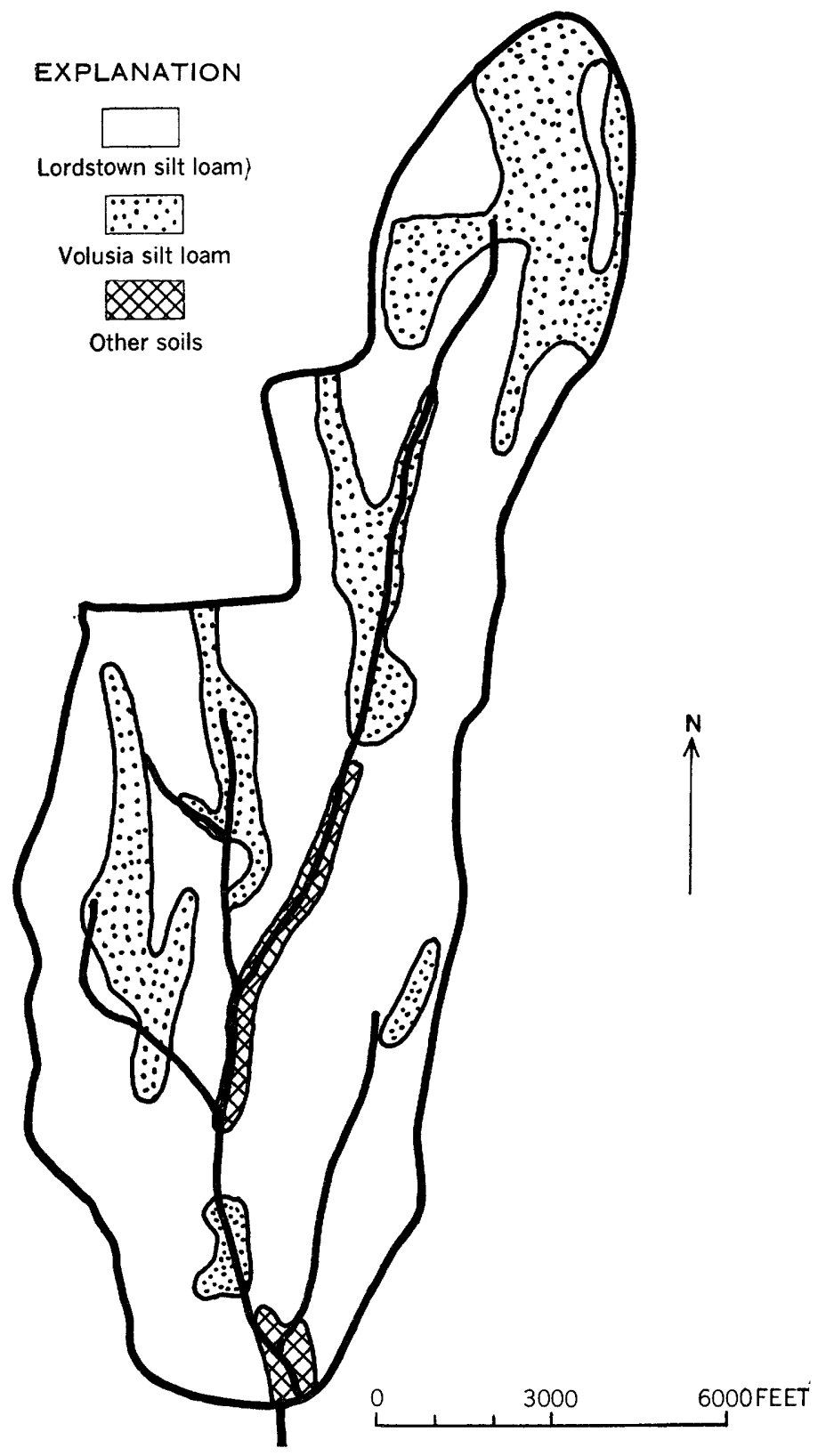

Figure 12,-Soils in Albright Creek area. 


\section{REFORESTATION OF THE STUDY AREAS}

Much of the land in the four watersheds had been cleared for farming by the early settlers. In general, about one-fifth of the land remained in second-growth mixed-deciduous woodlots. By 1930, large portions of the farmlands, particularly marginal lands at the higher elevations and with the steeper slopes, had been abandoned and allowed to develop a heavy cover of weeds and brush. Prior to the extensive reforestation that began in 1931, there were only 2 coniferous plantations totaling 46 acres in the 4 areas.

The reforestation consisted mostly of plantings of coniferous trees. Species of pine and spruce were predominant, with a few larches and firs interspersed in a few areas. A few small plantings of black locust and black cherry trees were made in some areas. The seedlings were planted by placing the young tree in a slit made with a grubhoe and then back-filling the trench. Choice of the areas to be planted was governed by the boundaries of the state-owned land rather than by natural features such as ridges or slopes. Because of this manner of planting, none of the basins considered in this report was completely reforested.

Plant cover in the partly reforested watersheds was determined from two field surveys of each area. The surveys to determine plant cover prior to reforestation were made in 1933 on the Sage Brook area and the Shackham Brook area, and in 1935 on the Cold Spring Brook area. Although seedlings had been planted in the areas when these surveys were made, the surveys represent the plant cover prior to the reforestation. Surveys to determine plant cover after reforestation were made in 1948 for all three areas. A summary of these two surveys is given in table 1, which also includes information on the Albright Creek area. Comparison of the 2 surveys indicate that 47 percent of the Sage Brook area, 35 percent of the Cold Spring

TABLE 1.-Types of cover in study areas

\begin{tabular}{|c|c|c|c|c|c|c|c|c|c|}
\hline \multirow{3}{*}{ Area } & \multirow{3}{*}{ Year } & \multicolumn{8}{|c|}{ Type of cover } \\
\hline & & \multicolumn{2}{|c|}{ Deciduous } & \multicolumn{2}{|c|}{ Coniferous } & \multicolumn{2}{|c|}{ Mixed woodlot } & \multicolumn{2}{|c|}{$\begin{array}{l}\text { Pasture and } \\
\text { crops }\end{array}$} \\
\hline & & Acres & Percent & Acres & Percent & Acres & Percent & Acres & Percent \\
\hline $\begin{array}{l}\text { Sage Brook } \\
\text { Cold Spring Brook...... } \\
\text { Shackham Brook } \\
\text { Albright Creek. }\end{array}$ & $\begin{array}{c}11933 \\
1948,1958 \\
11933 \\
1948,1958 \\
11933 \\
1948,1958 \\
1948,1958\end{array}$ & $\begin{array}{r}97 \\
132 \\
500 \\
500 \\
504 \\
546 \\
904\end{array}$ & $\begin{array}{l}22 \\
30 \\
51 \\
51 \\
25 \\
27 \\
20\end{array}$ & $\begin{array}{r}27 \\
188 \\
0 \\
250 \\
19 \\
1,125 \\
0\end{array}$ & $\begin{array}{r}6 \\
43 \\
0 \\
26 \\
1 \\
57 \\
0\end{array}$ & $\begin{array}{r}53 \\
64 \\
0 \\
90 \\
0 \\
0 \\
0\end{array}$ & $\begin{array}{r}12 \\
14 \\
0 \\
9 \\
0 \\
0 \\
0\end{array}$ & $\begin{array}{r}265 \\
58 \\
475 \\
135 \\
1,474 \\
326 \\
3,627\end{array}$ & $\begin{array}{l}60 \\
13 \\
49 \\
14 \\
74 \\
16 \\
80\end{array}$ \\
\hline
\end{tabular}

2 Prior to reforestation. 
Brook area, and 58 percent of the Shackham Brook area were reforested.

The 1948 surveys also included estimates of the crown cover of the trees as a percentage of total ground area for both the Cold Spring Brook area and the Shackham Brook area. For example, an estimate of 60 percent crown cover indicates that the canopy of the trees in the area cover 60 percent of the ground surface, and that the openings between the trees represent the remaining 40 percent of surface area. The surveys were made during the growing season, when the deciduous trees were in full foliage. The cover for the three areas also was determined in 1958 A summary of the data on crown cover is given in table 2 .

The field surveys made in 1958 also measured the average size and density of the trees in the reforested area. The surveys indicated that generally the tree heights averaged from about 25 feet for the spruces to more than 40 feet for the larches.

Plant cover for the Albright Creek area was determined from aerial photographs taken in 1948, and checked by field reconnaissance in 1958. The field check indicated that no changes in land use took place between 1948 and 1958. Engineers of the Geological Survey who visited the area between 1941 and 1948 reported little or no change in land use during this period. Therefore, the estimate of 20 percent deciduous woodlots and 80 percent pasture and croplands represents the land use in the Albright Creek basin for the entire period of record used in this study.

Table 3 is a list of types of trees planted in the reforestation program. Information contained in tables 4 through 6 indicates in a general way the planting pattern used by the foresters. Maps of the areas delineating the reforested sections, the types of plant cover, and the percents of crown cover were prepared from data obtained from the field surveys previously described, and are shown in figures 13 through 22.

TABLE 2,-Crown cover in reforested areas

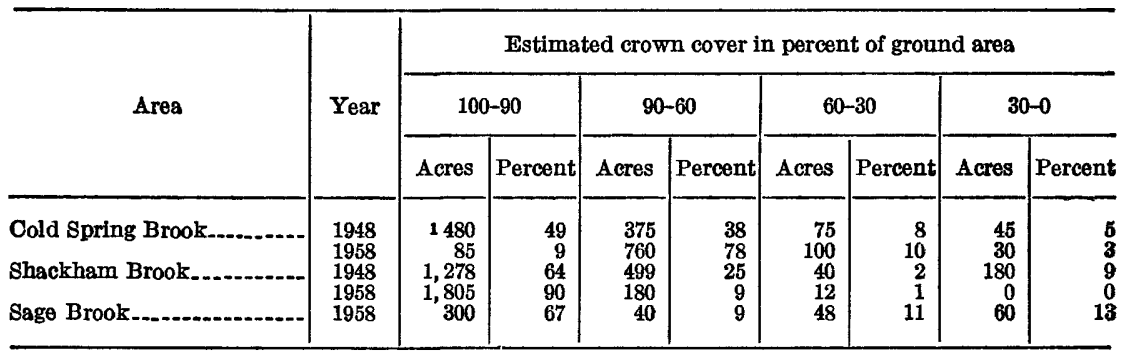

1395 acres estimated at 90 percent in 1948 and at 85 percent in 1958. 


\section{TABLE 3.-List of species planted in reforestation program}

Balsam fir

\section{Common name}

Black cherry

Black locust

European larch

Norway spruce

Red pine

Scotch pine

White pine

White spruce
Species

Abies balsamea (Linneaus) Miller

Prunus serotina Ehrhart

Robinia pseudoacacia Linneaus

Larix decidua Miller

Picea abies (Linneaus) Karsten

Pinus resinosa Aiton

Pinus sylvestris Linneaus

Pinus strobus Linneaus

Picea glauca (Moench) Voss

\section{TABLE 4.-Reforestation in Sage Brook area}

[Block numbers refer to figure 13]

\begin{tabular}{|c|c|c|c|c|c|c|c|}
\hline \multirow[b]{2}{*}{ Block } & \multirow[b]{2}{*}{$\begin{array}{l}\text { Acreage } \\
\text { of block }\end{array}$} & \multirow[b]{2}{*}{ Date planted } & \multirow{2}{*}{\multicolumn{2}{|c|}{ Number and kind of trees }} & \multicolumn{3}{|c|}{ A verage size and density in 1958} \\
\hline & & & & & $\begin{array}{c}\text { Helght } \\
\text { (feet) }\end{array}$ & $\begin{array}{l}\text { Diameter } \\
\text { (DBH) } \\
\text { (inches) }\end{array}$ & $\begin{array}{l}\text { Prees } \\
\text { per } \\
\text { acre }\end{array}$ \\
\hline 1 & 21 & May 1932_.. & 4,425 & Norway spruce............ & 42 & 4.9 & 520 \\
\hline $\begin{array}{l}2 \\
3 \\
4\end{array}$ & $\begin{array}{l}39 \\
29 \\
30\end{array}$ & 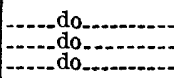 & $\begin{array}{l}30,250 \\
35,087 \\
24,200\end{array}$ & $\begin{array}{l}\text { Norway spruce. } \\
\text { Balsam fir } \\
\text { Red pine. }\end{array}$ & $\begin{array}{l}24 \\
22 \\
31\end{array}$ & $\begin{array}{l}4.4 \\
3.6 \\
5.8\end{array}$ & $\begin{array}{l}720 \\
485 \\
313\end{array}$ \\
\hline $\begin{array}{l}\mathbf{5} \\
\mathbf{6}\end{array}$ & $\begin{array}{l}32 \\
88\end{array}$ & 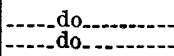 & $\begin{array}{r}30,600 \\
136,795\end{array}$ & $\begin{array}{l}\text { Norway spruce } \\
\text { White spruce. } \\
\text { Norway spruce. }\end{array}$ & 34 & $\begin{array}{l}3 . \overline{8} \\
4.1\end{array}$ & $\begin{array}{l}395 \\
820\end{array}$ \\
\hline
\end{tabular}

TABLE 5.-Reforestation in Cold Spring Brook area

[Block numbers refer to figure 14]

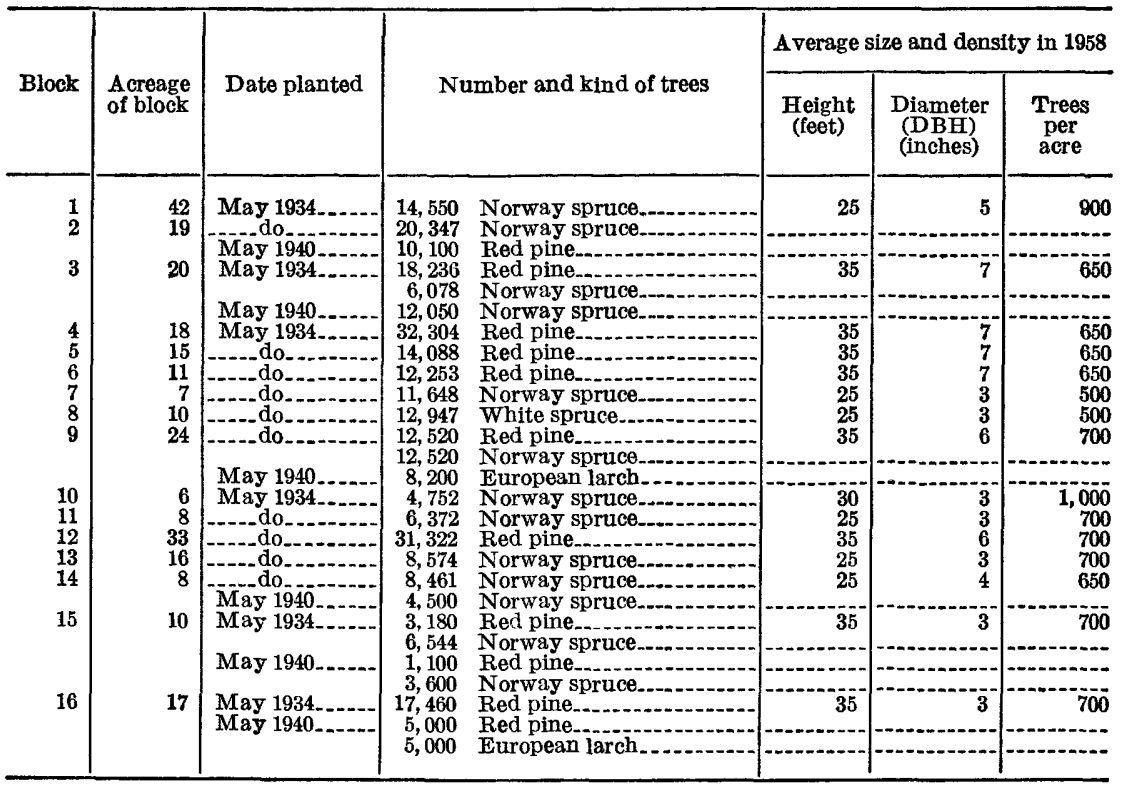


TABLE 6.-Reforestation in Shackham Brook area

[Block numbers refer to figure 15. Block acreage includes acreage outside watershed]

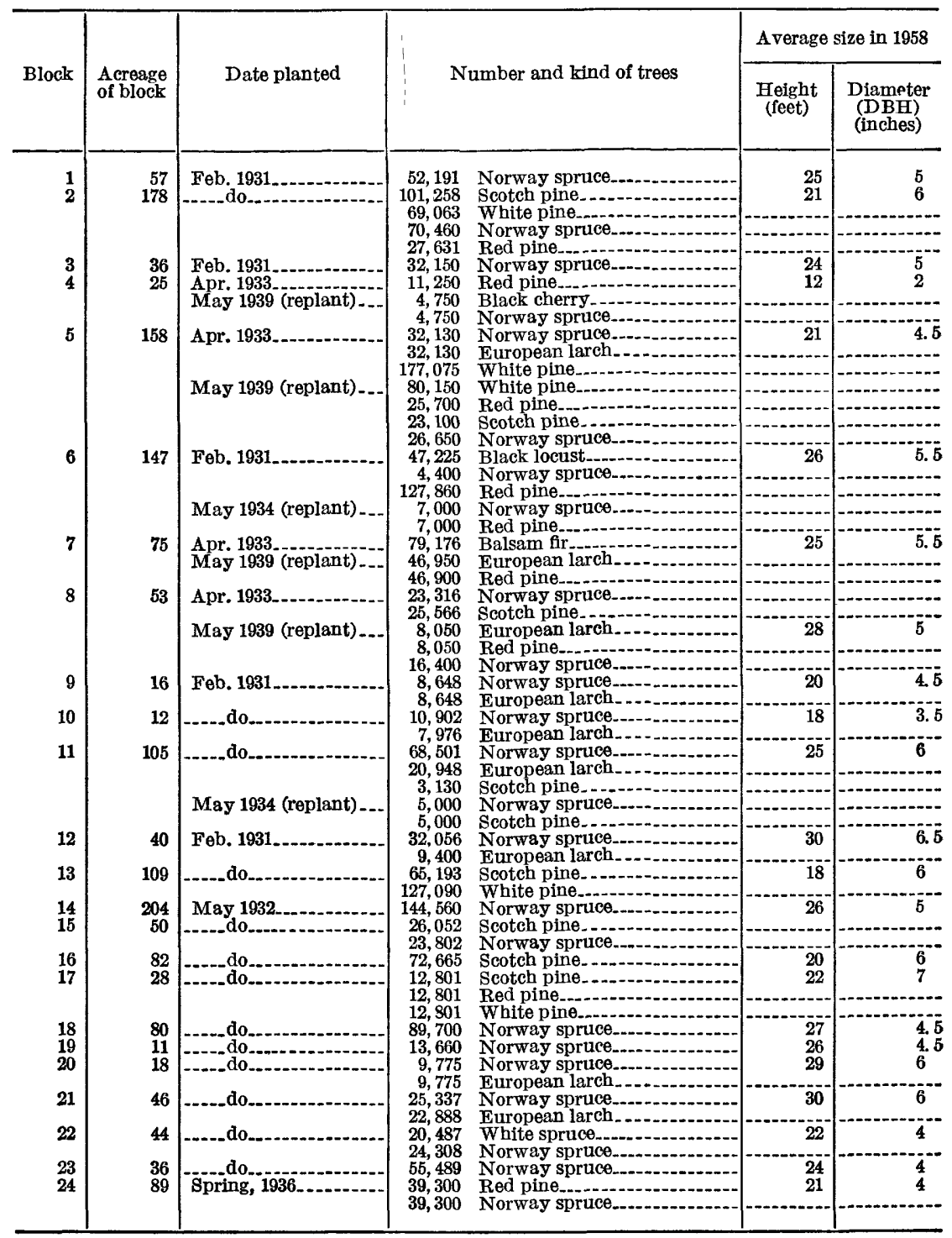




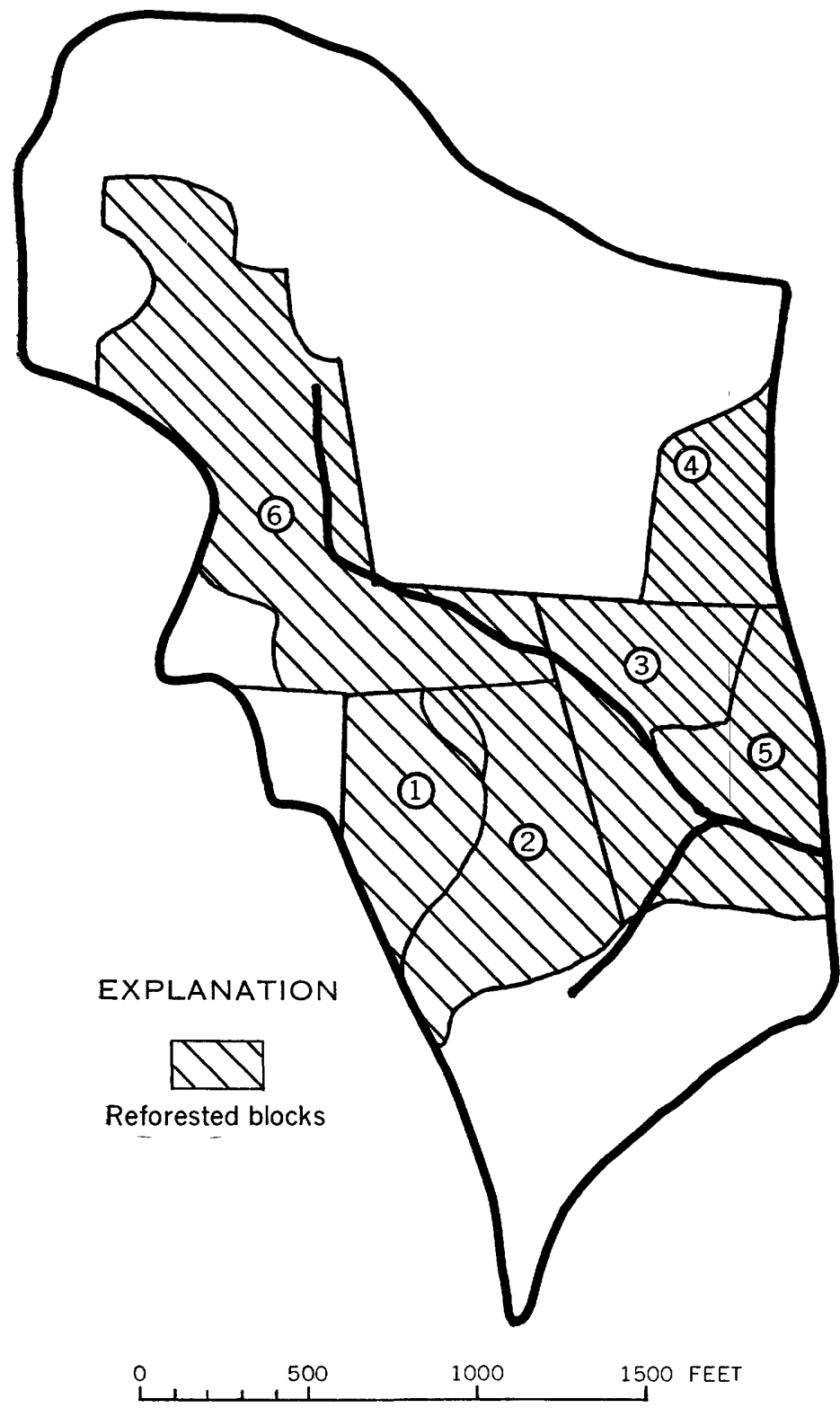

Figure 13.-Reforestation in Sage Brook area. Block numbers refer to table 4. 


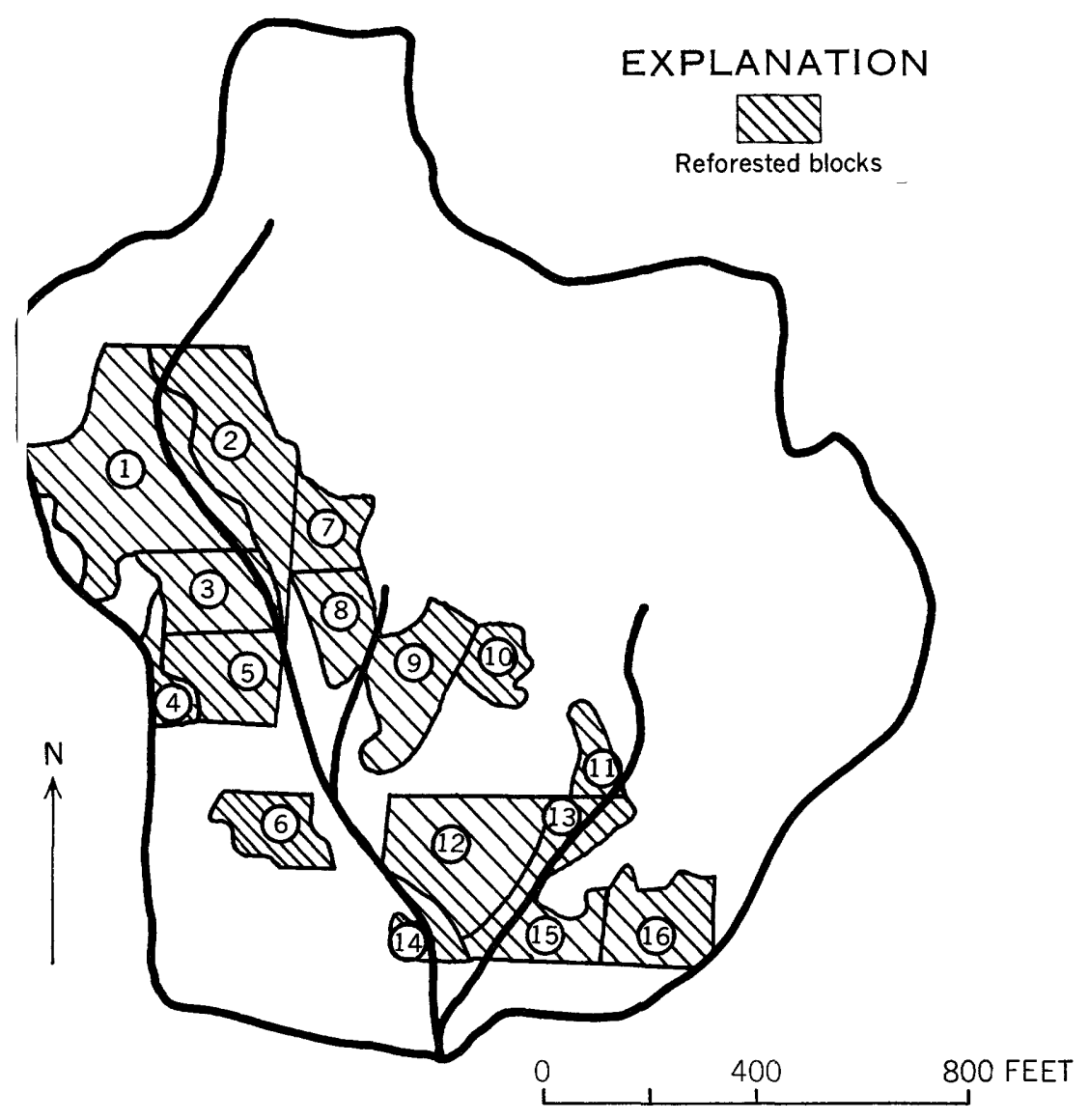

FIGURE 14.-Reforestation in Cold Spring Brook area. Block numbers refer to table 5. 


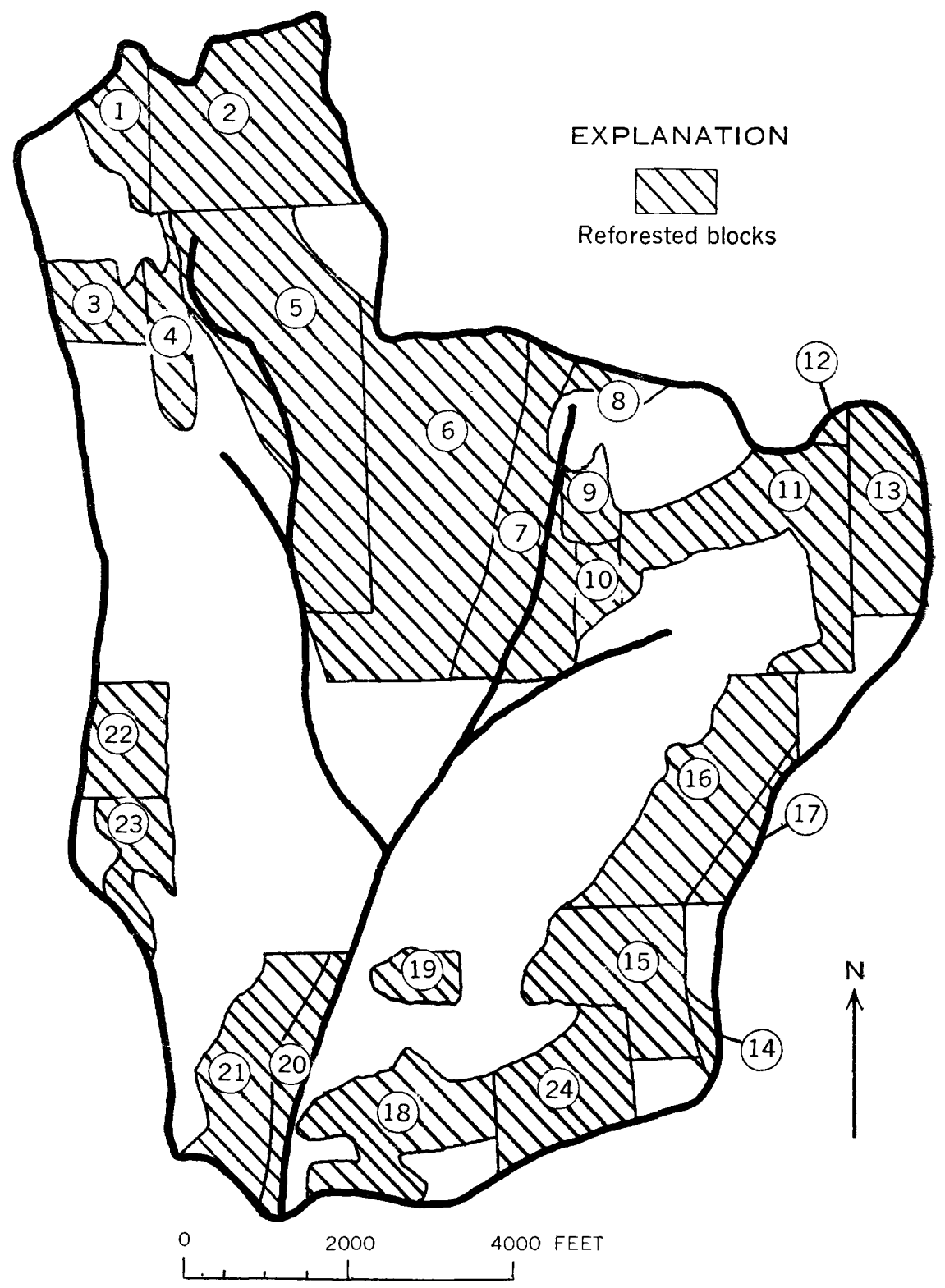

FraURe 15.-Reforestation in Shackham Brook area. Block numbers refer to table 6. 


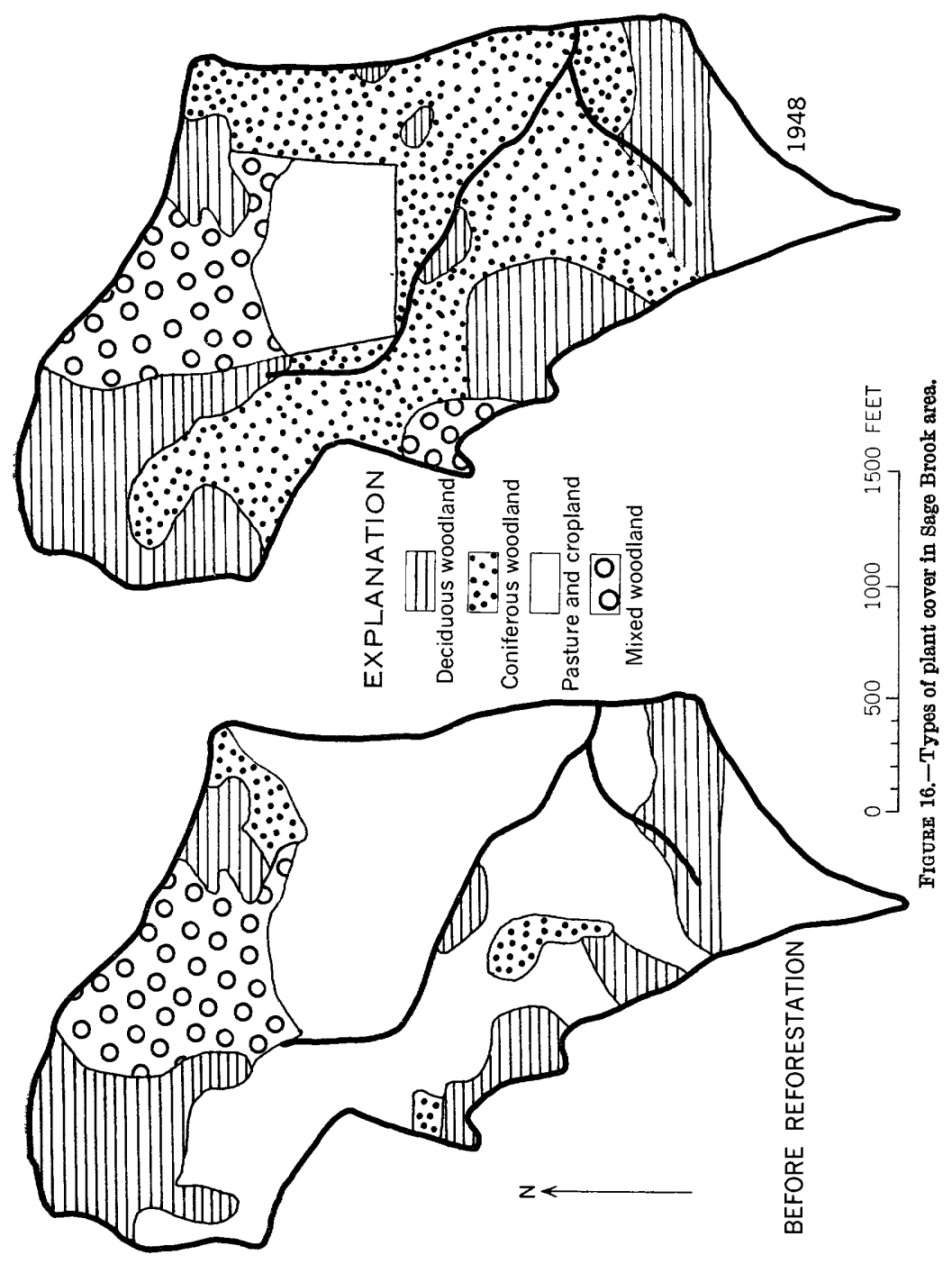




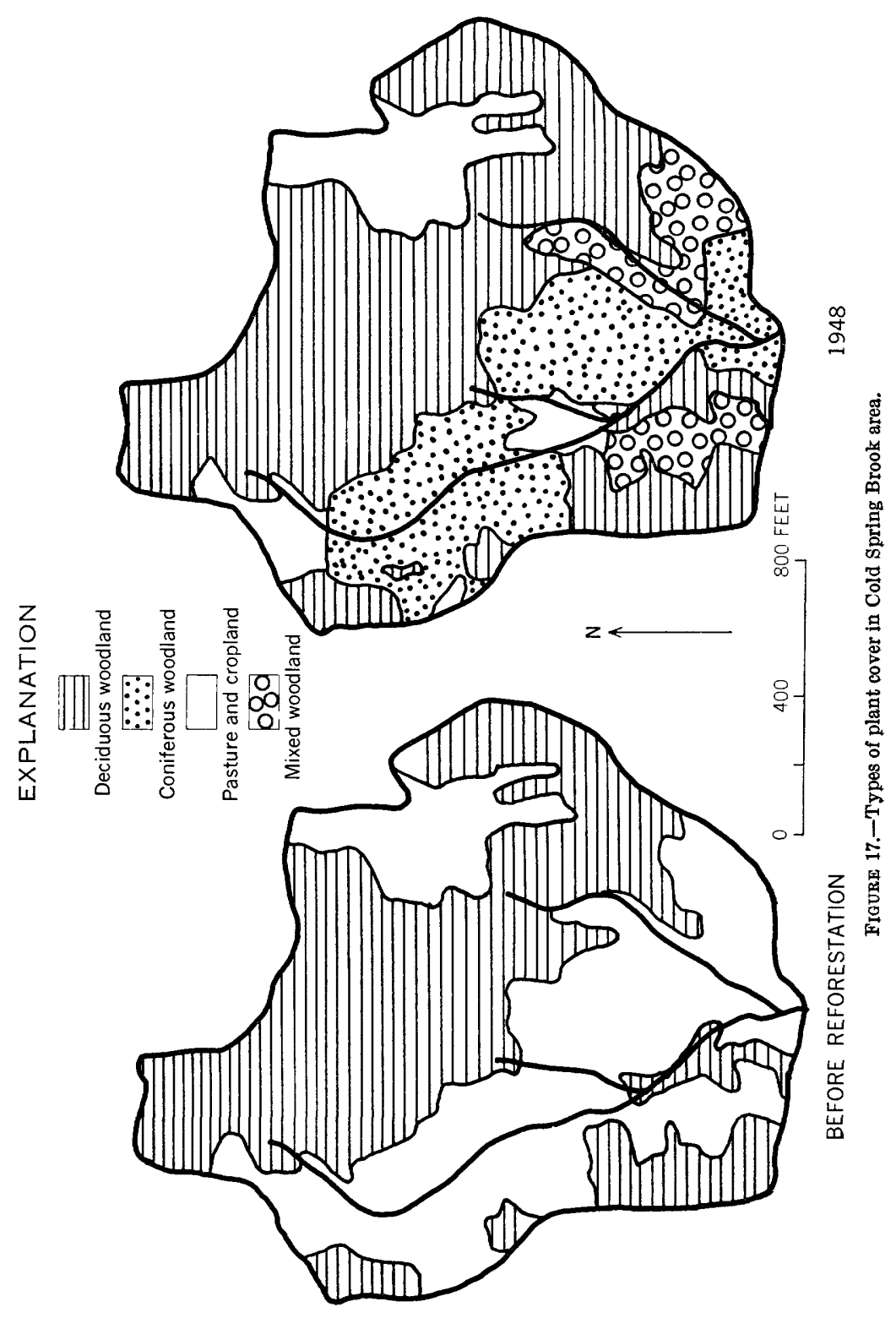




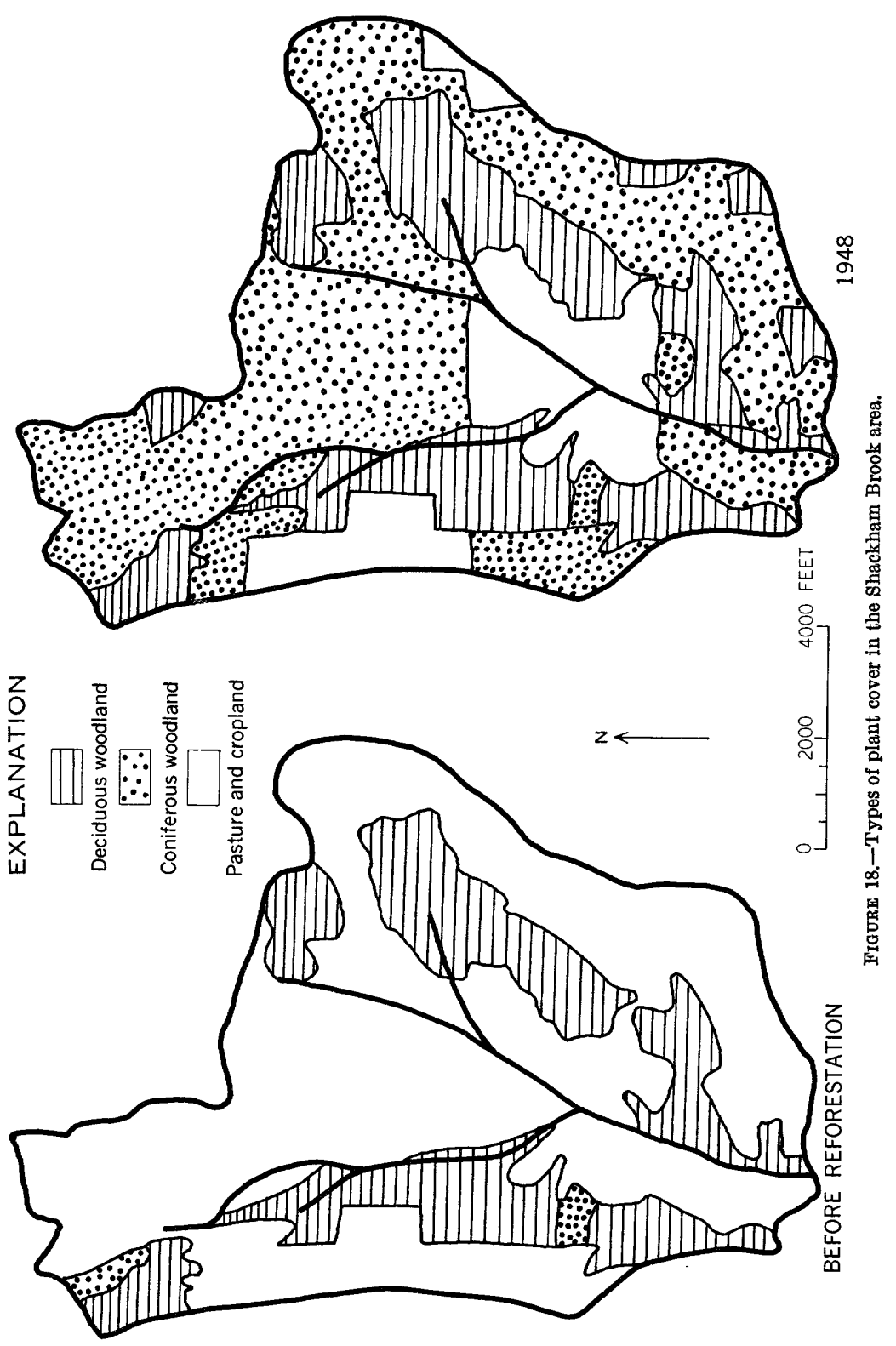


EXPLANATION

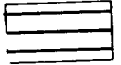

Deciduous woodland

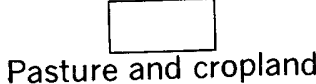

Pasture and cropland

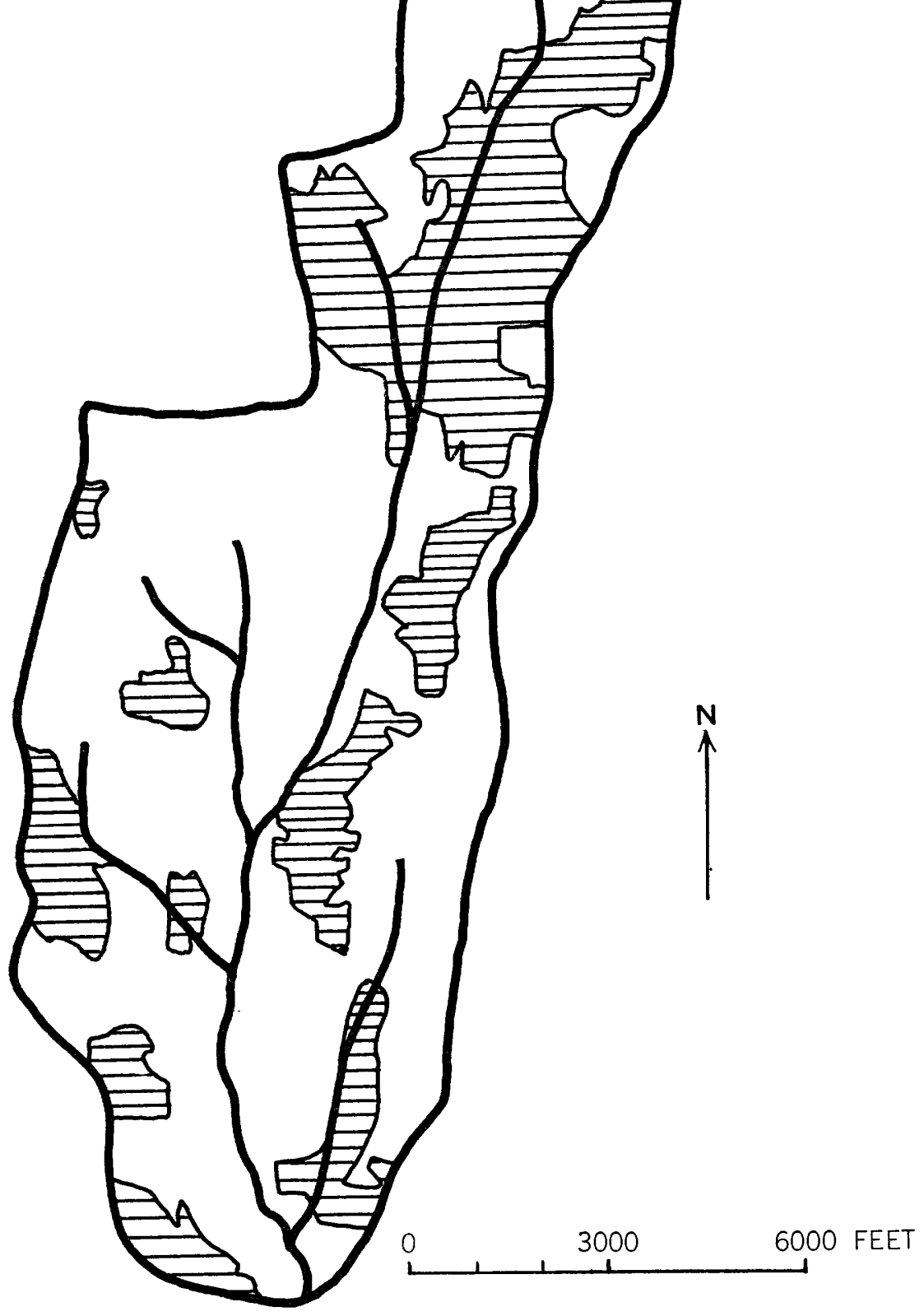

FIGURE 19.-Types of plant cover in Albright Creek area. 


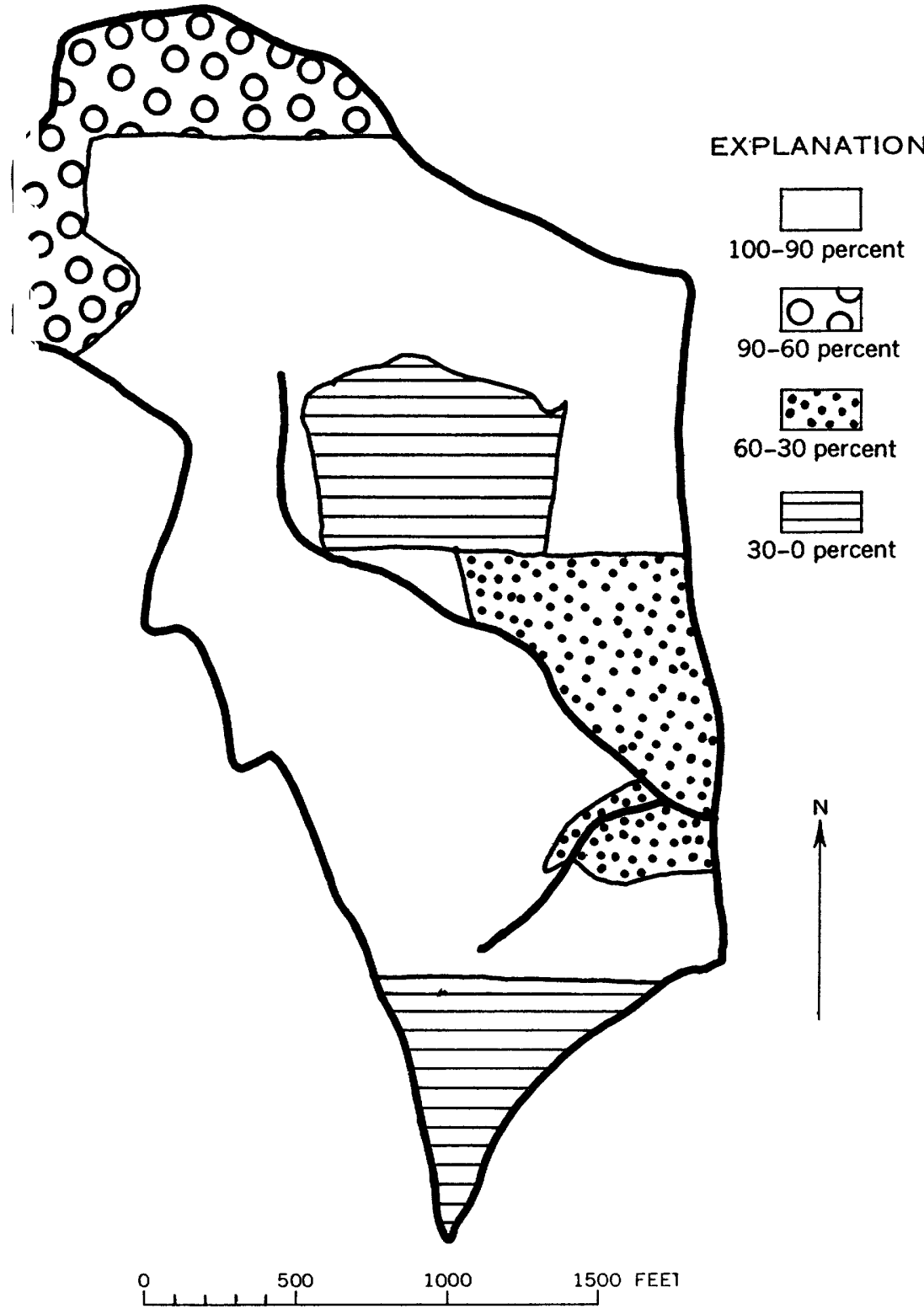

Figure 20.-Percentage of crown cover in Sage Brook area, 1948. 


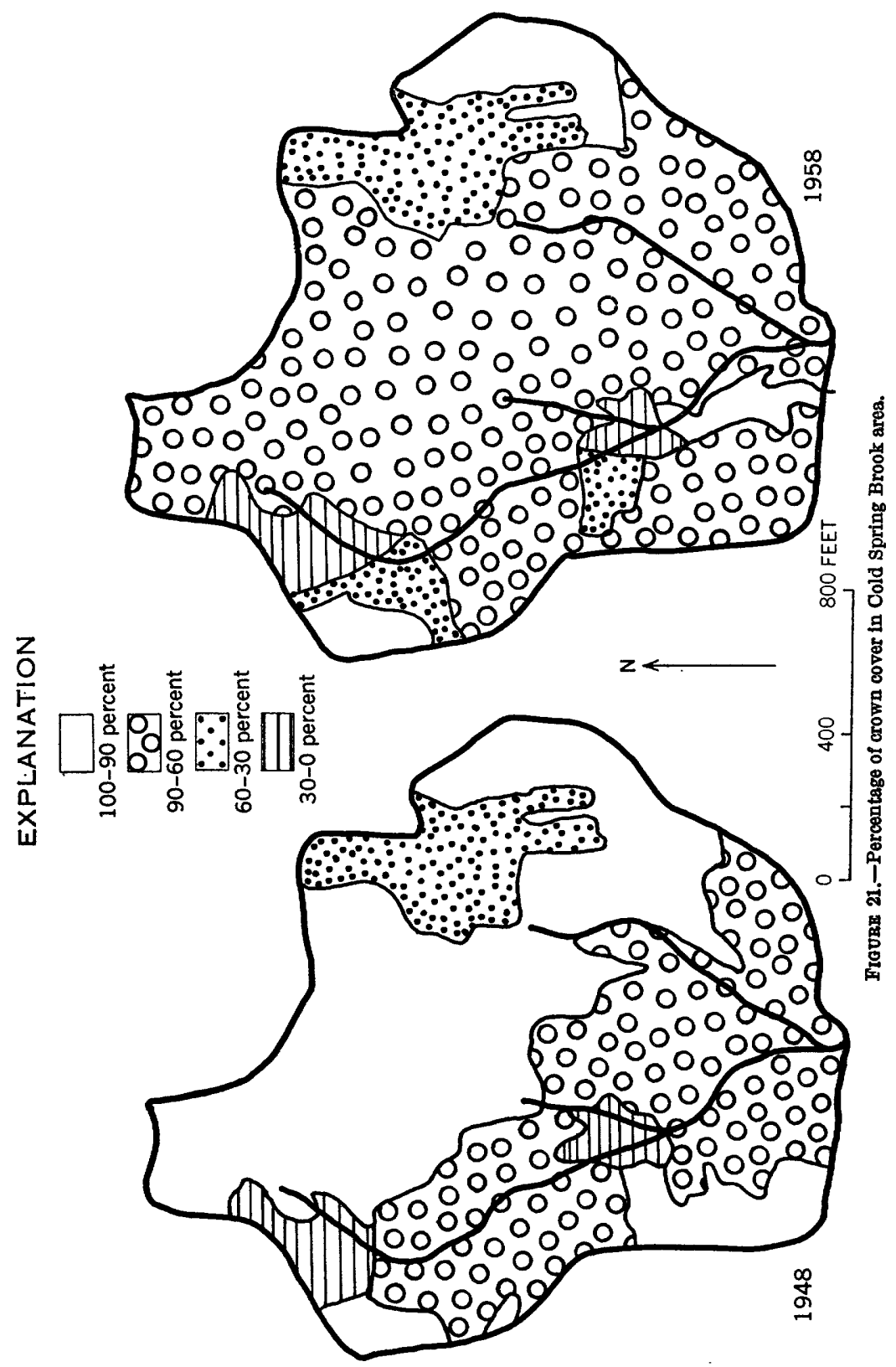




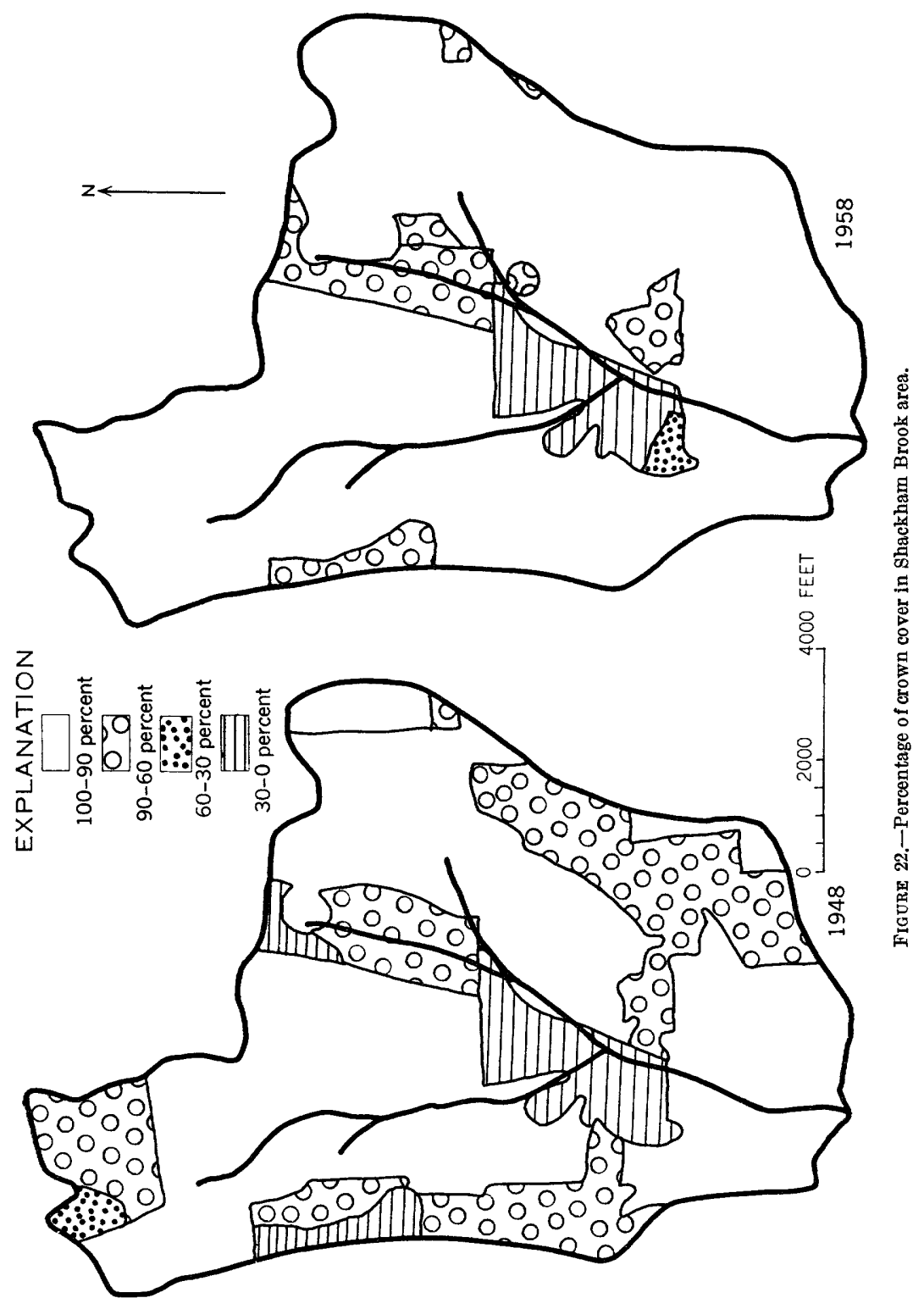




\section{RECORDS AVAILABLE}

\section{STREAMFLOW}

Stream-gaging stations were established on Shackham Brook near Truxton on November 26, 1932; on Sage Brook near South New Berlin on November 29, 1932; on Cold Spring Brook at China on November 22, 1935; and on Albright Creek at East Homer on October 21, 1938. Data-collecting facilities on Shackham Brook, Sage Brook, and Cold Spring Brook consist of continuous water-stage recorders and concrete controls with V-notch weirs; on Albright Creek, a continuous water-stage recorder and concrete control. Records of discharge and runoff have been published annually in Geological Survey Water-Supply Papers entitled "Records of Surface Water of the United States, Part 1B."

\section{PRECIPITATION}

Both recording and nonrecording gages were used to measure precipitation in the four areas. The recording gages are of the 8-inch weighing type; the nonrecording gages are of the 4-inch tube type from which the total catch is determined volumetrically. The gages were not shielded.

Precipitation for the Shackham Brook area was measured by recording gage 1 , near the center of the basin, and recording gage 2, located about 500 feet higher in elevation and 1,000 feet west of gage 1. Records from gage 1 consist of weekly recorder charts from January 1, 1933, to June 25, 1937, and daily recorder charts thereafter. Weekly recorder charts from gage 2 are available from October 22, 1935.

Precipitation for the Sage Brook area was measured at a site about 800 feet upstream the stream-gaging station. Records from a nonrecording gage are available from December 1932. From June 1, 1935 both a recording and a nonrecording gage were in operation, the former providing a record on a weekly chart. Precipitation totals from the nonrecording gage were measured daily prior to June, 1935, and weekly thereafter.

Precipitation for the Cold Spring Brook area was measured by a recording gage located several hundred feet east of the streamflow station. Weekly recorder charts are available from October 24, 1934. A nonrecording gage also measured precipitation at the same location since January 26, 1940.

Precipitation for the Albright Creek area was measured by recording gage 1 , located near the center of the area, and by nonrecording gage 2, located about 4,000 feet upstream from the recording gage. Weekly 
recorder charts from recording gage 1 are available from October 22, 1938; daily totals of nonrecording gage 2 have been measured since April 4, 1940.

Data obtained from all recording gages, and from the nonrecording gage in the Sage Brook area, are published in U.S. Weather Bureau Hydrologic Bulletins, North Atlantic District. Locations of the precipitation gages are shown in figures 5 to 8 .

\section{HYDROLOGIC ANALYSES}

In the selection of a method of hydrologic analysis, certain basic assumptions must be made. These assumptions are (a) that the data adequately describe the variables under consideration, and (b) that the relation between the variables is properly described. The reliability of the interpretations or conclusions of an analysis is directly related to the validity of these assumptions.

The reliability and completeness of the data collected in the four study areas formed the basis for selection of the methods of analysis. Methods of analysis therefore were limited to those for which complete and reliable indexes of the variables could be determined. The indexes used in the analyses were evaluated and tested for both consistency and reliability. The type of data available for analysis, as well as its consistency, governed the selection of the analytical techniques described in this report.

In relating the various indexes, or variables, time was used as a factor in determining whether a change in the relationship between the variables had occurred. Because changes in cover of the reforested areas progressed gradually from brush and weeds to coniferous woodland, it was assumed that any changes in streamflow resulting from the reforestation also would be gradual. Therefore changes which occurred in the streamflow from the reforested areas were determined from hydrologic analyses that were designed to detect trendlike changes occurring gradually from the time the trees were planted until 1958.

\section{RELIABILITY OF DATA}

STRRAMFLOW DATA

Streamflow data were computed on a daily basis for the four study areas from stage-discharge relations established for each of the stream-gaging stations. Because of the stability of the stage-discharge relation, the records for all four stations are considered accurate measurements of the streamflow except for very brief periods when the relation cannot be applied. Estimates of flow made for these brief periods total generally less than 1 or 2 percent of the annual streamflow and therefore represent a negligible amount of error. The 


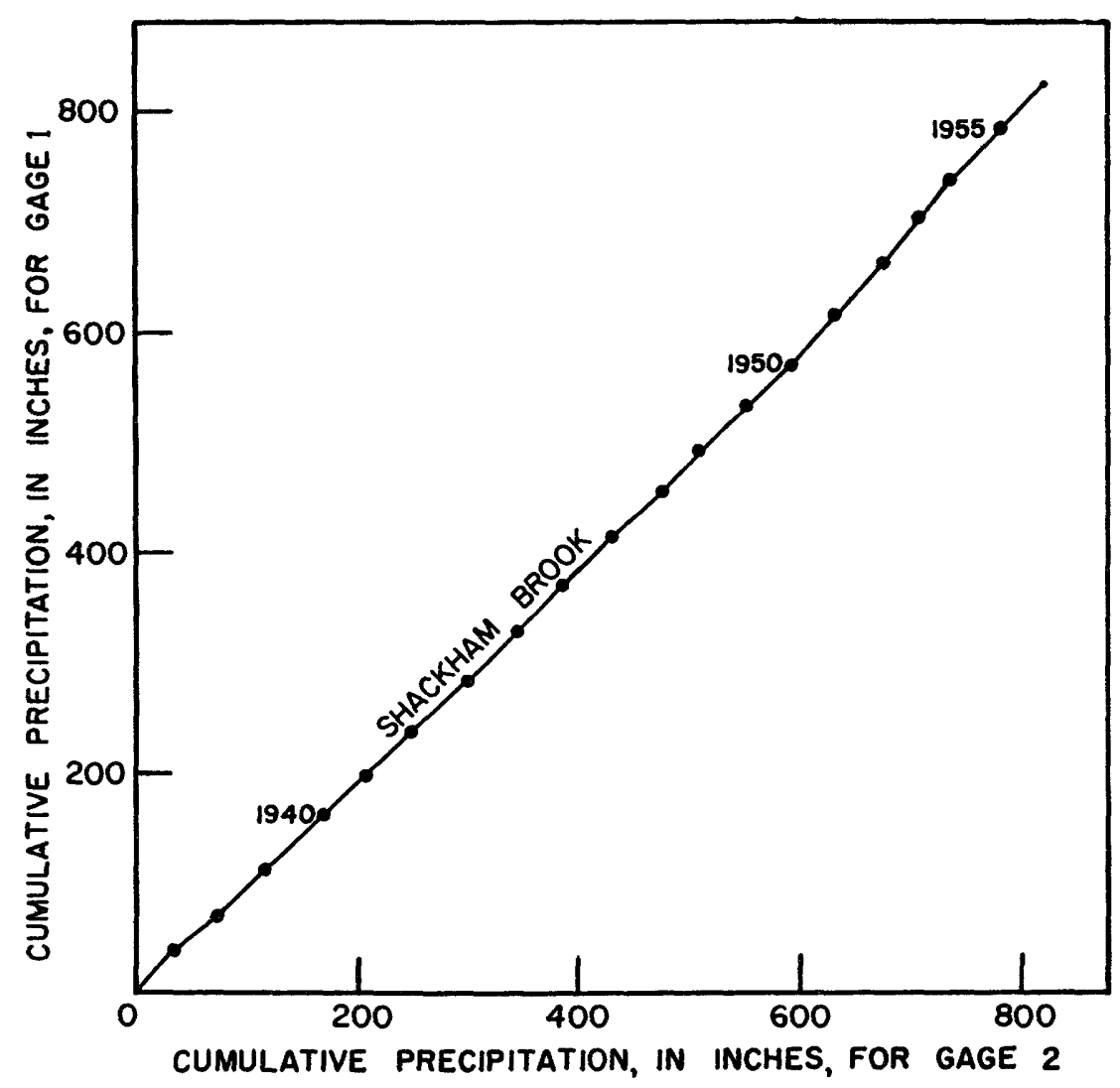

FIGURE 23.-Relation between precipitation gages 1 and 2 for Shackham Brook area.

use of the artificial controls anchored to bedrock insures that all streamflow leaving the basin passes the control section, and that subsurface flow passing the gaging station is negligible.

\section{PRECIPITATION DATA}

The precipitation data collected in the four study areas were thoroughly analyzed to determine the consistency as an index of the actual basin precipitation. Several tests were made to determine this reliability. Each record was analyzed for any trend or abrupt change in the measured precipitation, and the effects of location of the gages also were studied. The two methods used to detect changes were the double-mass curve technique and the time-trend analysis. The double-mass curve technique was used to determine any abrupt change in each of the precipitation records. The double-mass curve was constructed by plotting the cumulative precipitation for one gage 
against that of another gage or average for a group of gages for a concurrent period of record. An abrupt change in the slope of the resultant relation usually indicates some inconsistency in the record of one of the gages. The time-trend analysis was used to detect any gradual trend rather than abrupt change in the precipitation record. The analysis was made by correlating the precipitation with the year in which it occurred.

For the Shackham Brook and Albright Creek areas, the precipitation record of gage 1 was compared with the record of gage 2 for each respective area. The relation between cumulative precipitation for gages 1 and 2 in the Shackham Brook area is shown in figure 23. In both basins, the relation was fairly consistent throughout the period of concurrent record. However, the total precipitation measured by gage 2 exceeded that measured by gage 1 by 5 percent for the Albright Creek area and 2 percent for the Shackham Brook area. These differences are probably due to orographic effects caused by differences in elevation and exposure.

An areal index of precipitation was determined from 7 first-order Weather Bureau gages that form a network around the study areas. The records for Ithaca, Cortland, Morrisville, Norwich, Utica, Cooperstown, and Delhi were used. These records were analyzed for consistency among themselves by comparing the records of each against the combined records of the remaining 6 gages using the double-mass curve technique. The location of these gages with respect to the study areas is shown in figure 1. Comparisons of cumulative precipitation for these stations indicated that the records were consistent and reliable. The precipitation records for Binghamton were not used because of an abrupt change in the record due to change in location and exposure of the gage. The areal index of precipitation for comparison with the records of precipitation in the study areas was obtained by averaging arithmetically the annual precipitation for the 7 stations.

Comparisons were made between precipitation records for the study areas and the areal index. The relations are shown graphically in figure 24. All precipitation records in the study areas showed good agreement with the index except for the record of Sage Brook. A change in the relation was noted for the years 1948-50 inclusive. An investigation of the record indicated that from August 1948 to 1950 , a mechanical malfunction of recording gage 1 caused an underregistering of precipitation. Corrections based on both the areal index and nonrecording gage 2 were therefore applied to the monthly precipitation totals for this period.

The precipitation record for each gage in the study areas also was tested for a trend toward increasing or decreasing precipitation over 


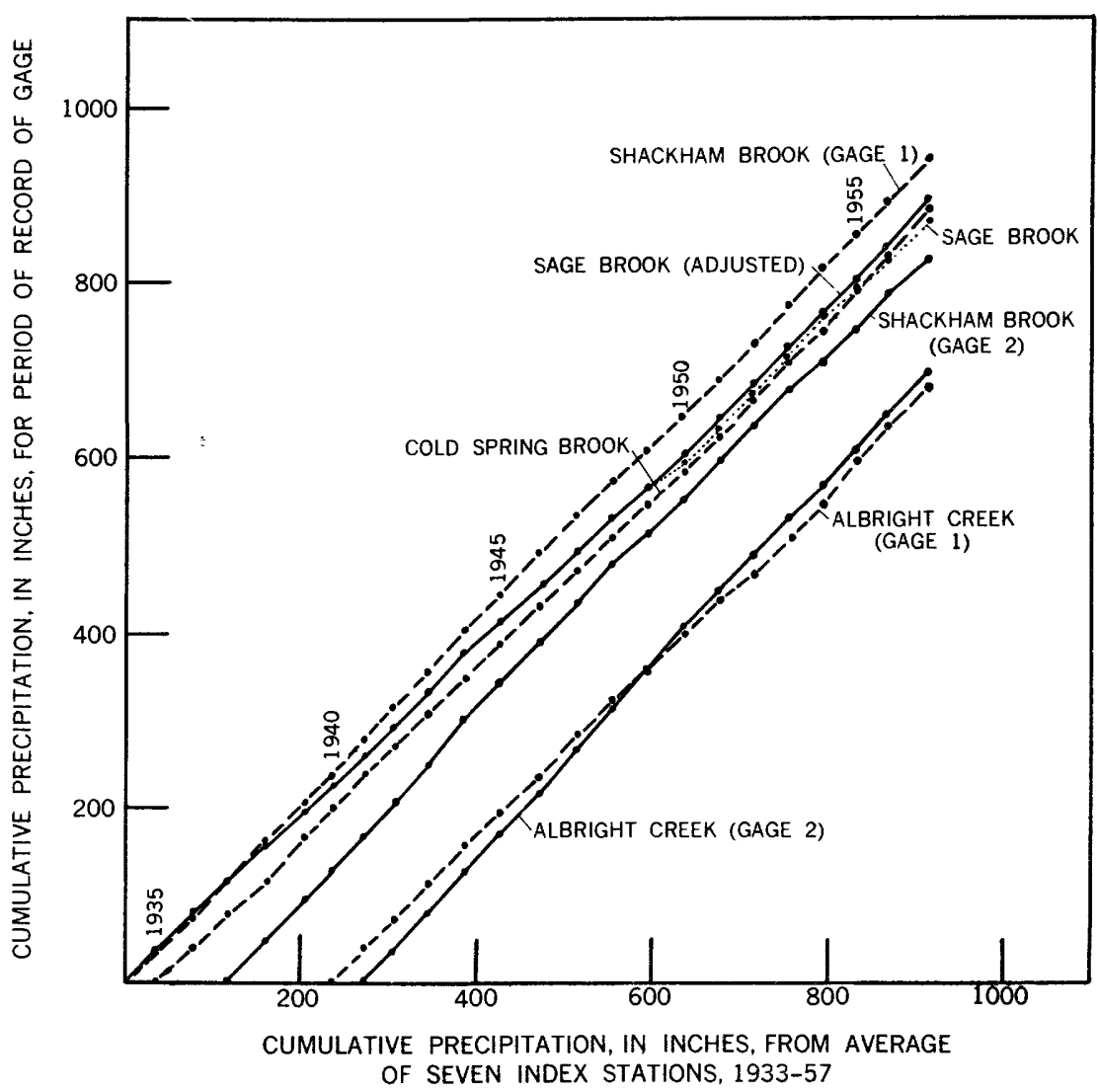

FiGURE 24.-Relation between cumulative precipitation for gages in study areas and cumulative areal index of precipitation.

the period of record. Tests for trends were made using the model equation

$$
P=a+b_{1} T
$$

in which $P$ is the annual precipitation and $T$ is the year of record of $P$ in numerical sequence beginning with $T=1$ for the first year of record. The test was made for each gage for both the 6-month seasonal periods ending April 30 and October 31, for the 12-month period ending April 30, and for the calendar year. The coefficient $b_{1}$ was tested for significant difference from zero as described by Snedecor (1946, p. 118-121). None of the precipitation records showed a statistically significant trend at the 95-percent level during the period of observation. Annual precipitation for 1934-57 recorded by gage 1 in the Shackham Brook area is shown in figure 25. 


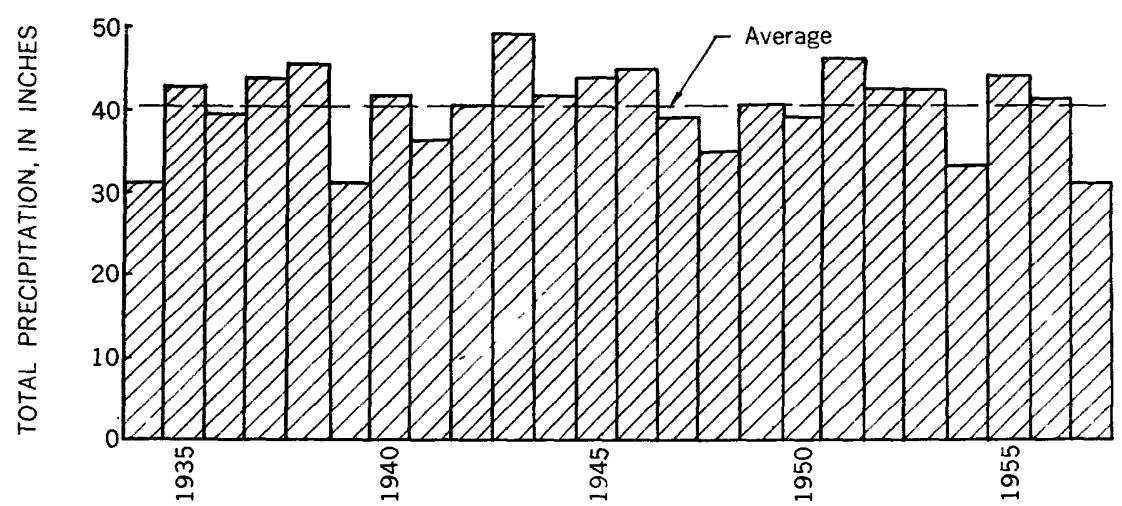

FIGURE 25.-Annual precipitation recorded by gage 1 in the Shackham Brook area.

On the basis of the tests previously described, all precipitation records for the study areas except for Sage Brook from August 1948 to July 1950 were considered reliable measures of the precipitation at the site. The record for the Sage Brook area from August 1948 to July 1950, with appropriate adjustments, also is considered consistent with the rest of the record.

\section{DETERMINATION OF PRECIPITATION INDEXES}

Recorded precipitation may not represent the average basin precipitation because of storm patterns or orographic effects. Therefore, in basins where more than one precipitation gage was operated, the precipitation data obtained from the gages in each basin were combined, and the average was considered to be a precipitation index for the basin. The data of the recording gage 1 in the Sage Brook, adjusted during the period August 1948 to July 1950, were used as the basin index from June 1935. Prior to this date, the record of nonrecording gage 2 was used. The data of the recording gage in the Cold Spring Brook area were used as an index of precipitation for that basin from October 1934. Since gage 2 was not operated in the Shackham Brook area until June 1936, the record of gage 1 adjusted to the relation between gages 1 and 2 was used as an index prior to June 1936, and the average of gages 1 and 2 used as an index of precipitation from May 1940. 


\section{RELATION BETWEEN RUNOFF AND PRECIPITATION}

Total runoff was correlated with associated precipitation for the four study areas to determine if changes in runoff occurred in any of the four areas. A correlation of monthly totals of runoff and precipitation was considered, but pilot correlations indicated poor results because of carryover effects from month to month. These carryover effects were of two general types: (a) the lag between rainfall and the resultant runoff occasionally resulted in a carryover of this runoff into the following month, and (b) the quantities of precipitation stored in the form of snow during the winter period varied from month to month. Neither of these carryover effects could be determined satisfactorily from the available data, particularly the precipitation stored as snow in the basins.

Because of these carryover effects, the precipitation-runoff relation was studied on seasonal and yearly bases. Although the growing season extends from about mid-May to about mid-October in the study areas, the period of May through October inclusive was used for the study. Consequently, the dormant season as considered in this study extended from November through April inclusive. In studying the relation between runoff and precipitation on a yearly basis, the hydrologic years ending March 31, April 30, June 30, September 30, October 31, and December 31 were considered. The data indicated that the best yearly relation between precipitation and runoff existed for the hydrologic year ending April 30. Therefore the 3 hydrologic periods used for this study were the 6-month periods ending April 30 and October 31 and the 12-month period ending April 30. These three periods are identical with those used by Johnson and Kovner (1956).

The effect of antecedent precipitation upon the relation between seasonal runoff and seasonal precipitation also was studied. The seasonal precipitation and the precipitation for the antecedent 6 -month period were combined in various proportions to obtain seasonal indexes of precipitation. The seasonal indexes were then correlated with the seasonal runoff. It was determined from the correlations that no significant carryover effect from antecedent precipitation existed for either the growing or dormant seasons, or for the hydrologic year. Therefore, the precipitation index, unadjusted for carryover effects, was used for correlation with runoff.

Runoff and precipitation totals for the three hydrologic periods at each of the study areas are listed in table 7. 


\section{CORRELATION ANALYSIS}

Total runoff was correlated with precipitation for each of the three hydrologic periods. Changes in the relation were determined by the establishment of a time-trend in the relation through the use of time as a third variable.

Several model equations were considered for a multiple correlation between precipitation, runoff, and time. The model equations considered were

$$
\begin{gathered}
R=a+b_{1} P+b_{2} T \\
R=a+b_{1} P+b_{2} T+b_{3} T^{2} \\
R=a+b_{1} P+b_{2} T+b_{3} T P \\
R=a+b_{1} P+b_{2} T P
\end{gathered}
$$

in which $R$ is the runoff in inches for the hydrologic period, $P$ is the precipitation index for the period, and $T$ is the position of the period in numerical sequence, beginning with $T=1$ for the first year of record. Correlations using the above models indicated that the equation

$$
R=a+b_{1} P+b_{2} T P
$$

best described the relations. The selection of equation 6 was based on a comparison of the standard errors of estimate for equations 2 to 5 using the data for the Shackham Brook area. The form of this equation indicates that the magnitude of a change in runoff is dependent upon the magnitude of the associated precipitation as well as the time sequence. Correlations therefore were made using this model equation for the three hydrologic periods at each of the four study areas. The significance of a time-trend change in runoff was determined from the probability of the $b_{2}$ coefficient differing from zero, as described by Ezekiel (1950, p. 321-325).

The time-trend change in runoff was significant at the 1-percent level for the 6-month hydrologic period ending April 30 for all 3 reforested areas. It was not significant at the 5-percent level for the correlations for the control area on Albright Creek, nor for the correlations for the other periods for the reforested areas. Therefore, 
for this latter group, linear correlations were recomputed using the equation

$$
R=a+b_{1} P \text {. }
$$

The regression equations for all three hydrologic periods for each of the four study areas are shown in table 8 . The relation for the Cold Spring Brook area for the 6-month period ending April 30 is shown graphically in figure 26.

TABLE 7.-Precipitation and runoff totals, in inches, for selected hydrologic periods

\begin{tabular}{|c|c|c|c|c|c|c|}
\hline \multirow{2}{*}{ Year } & \multicolumn{2}{|c|}{$\begin{array}{c}\text { 6-month period ending } \\
\text { A pril } 30\end{array}$} & \multicolumn{2}{|c|}{$\begin{array}{l}\text { 6-month period ending } \\
\text { October } 31\end{array}$} & \multicolumn{2}{|c|}{$\begin{array}{l}\text { 12-month period ending } \\
\text { April } 30\end{array}$} \\
\hline & Precipitation & Runoff & Precipitation & Runoff & Precipitation & Runoff \\
\hline \multicolumn{7}{|c|}{ Albright Creek area } \\
\hline $\begin{array}{l}1939 \\
1940 \\
1941 \\
1942 \\
1944 \\
1945 \\
1946 \\
1948 \\
1949 \\
19501 \\
1952 \\
1953 \\
1954 \\
1956 \\
1957\end{array}$ & $\begin{array}{l}16.78 \\
16.71 \\
14.27 \\
23.59 \\
14.48 \\
19.14 \\
15.53 \\
16.45 \\
17.47 \\
20.88 \\
20.20 \\
20.78 \\
17.93 \\
22.07 \\
19.98 \\
23.96 \\
19.97 \\
16.13\end{array}$ & $\begin{array}{l}16.41 \\
16.90 \\
17.88 \\
14.76 \\
23.70 \\
16.31 \\
18.22 \\
15.13 \\
19.26 \\
15.50 \\
15.89 \\
19.63 \\
21.75 \\
16.30 \\
15.53 \\
13.60 \\
19.98 \\
22.65 \\
15.65\end{array}$ & $\begin{array}{l}21.11 \\
20.19 \\
25.47 \\
26.67 \\
21.02 \\
28.40 \\
29.20 \\
25.55 \\
22.27 \\
23.75 \\
21.15 \\
15.46 \\
23.27 \\
17.76 \\
23.92 \\
25.27 \\
24.14 \\
26.68\end{array}$ & $\begin{array}{r}1.07 \\
6.77 \\
1.59 \\
6.15 \\
9.62 \\
5.45 \\
11.54 \\
11.01 \\
11.62 \\
6.08 \\
4.45 \\
4.84 \\
2.11 \\
4.16 \\
2.93 \\
4.79 \\
3.30 \\
4.96 \\
5.70\end{array}$ & $\begin{array}{l}37.82 \\
34.46 \\
49.06 \\
41.15 \\
40.16 \\
43.93 \\
45.65 \\
43.02 \\
43.15 \\
43.95 \\
41.93 \\
33.39 \\
45.34 \\
37.74 \\
47.88 \\
45.24 \\
40.27\end{array}$ & $\begin{array}{l}17.97 \\
24.65 \\
16.35 \\
29.85 \\
25.93 \\
23.67 \\
26.67 \\
30.27 \\
27.12 \\
21.97 \\
24.08 \\
26.59 \\
18.41 \\
19.69 \\
16.53 \\
24.77 \\
25.95 \\
20.61\end{array}$ \\
\hline
\end{tabular}

Cold Spring Brook area

\begin{tabular}{|c|c|c|c|c|c|c|}
\hline $\begin{array}{l}1935 \\
1936 \\
1938 \\
1949 \\
1941\end{array}$ & $\begin{array}{l}15.78 \\
20.32 \\
16.83 \\
14.01 \\
18.25 \\
15.33 \\
15.06 \\
12.61 \\
19.47 \\
13.59 \\
19.10 \\
14.30 \\
16.42 \\
21.07 \\
17.93 \\
19.81 \\
22.47 \\
22.39 \\
23.18 \\
20.04 \\
24.64 \\
21.85 \\
18.14\end{array}$ & $\begin{array}{l}17.94 \\
26.57 \\
16.75 \\
13.70 \\
20.40 \\
18.63 \\
15.90 \\
11.94 \\
19.53 \\
13.26 \\
20.69 \\
15.43 \\
17.13 \\
17.91 \\
15.76 \\
22.02 \\
22.54 \\
19.11 \\
16.45 \\
16.44 \\
20.06 \\
23.15 \\
14.94\end{array}$ & $\begin{array}{l}21.87 \\
18.80 \\
24.62 \\
31.38 \\
19.13 \\
18.96 \\
17.52 \\
25.66 \\
24.75 \\
17.87 \\
26.46 \\
26.45 \\
19.37 \\
21.56 \\
14.22 \\
19.50 \\
22.10 \\
20.97 \\
19.15 \\
19.56 \\
\mathbf{3 2 . 7 4} \\
\mathbf{2 2 . 8 3} \\
\mathbf{2 1 . 5 2}\end{array}$ & $\begin{array}{r}7.88 \\
3.10 \\
5.65 \\
10.47 \\
2.25 \\
3.54 \\
1.96 \\
6.74 \\
8.57 \\
2.64 \\
11.38 \\
9.24 \\
9.70 \\
6.89 \\
4.21 \\
6.50 \\
4.98 \\
4.10 \\
4.47 \\
4.45 \\
9.82 \\
6.34 \\
3.52\end{array}$ & $\begin{array}{l}42.19 \\
35.63 \\
38.63 \\
49.63 \\
34.46 \\
34.02 \\
30.13 \\
45.13 \\
38.34 \\
36.97 \\
40.76 \\
42.87 \\
40.44 \\
39.49 \\
34.03 \\
41.97 \\
44.49 \\
44.15 \\
39.19 \\
44.20 \\
54.59 \\
40.97\end{array}$ & $\begin{array}{l}34.45 \\
19.85 \\
19.35 \\
30.87 \\
20.88 \\
19.44 \\
13.90 \\
26.27 \\
21.83 \\
23.33 \\
26.81 \\
26.37 \\
27.61 \\
22.65 \\
26.23 \\
29.04 \\
24.09 \\
20.55 \\
20.91 \\
24.51 \\
32.97 \\
21.28\end{array}$ \\
\hline
\end{tabular}


TABLE 7.-Precipitation and runoff totals, in inches, for selected hydrologic periods-Continued

\begin{tabular}{|c|c|c|c|c|c|c|}
\hline \multirow{2}{*}{ Year } & \multicolumn{2}{|c|}{$\begin{array}{l}\text { 6-month period ending } \\
\text { April } 30\end{array}$} & \multicolumn{2}{|c|}{$\begin{array}{l}\text { 6-month period ending } \\
\text { October } 31\end{array}$} & \multicolumn{2}{|c|}{$\begin{array}{l}\text { 12-month period ending } \\
\text { A pril } 30\end{array}$} \\
\hline & Precipitation & Runoff & Precipitation & Runoff & Precipitation & Runoff \\
\hline
\end{tabular}

Sage Brook area

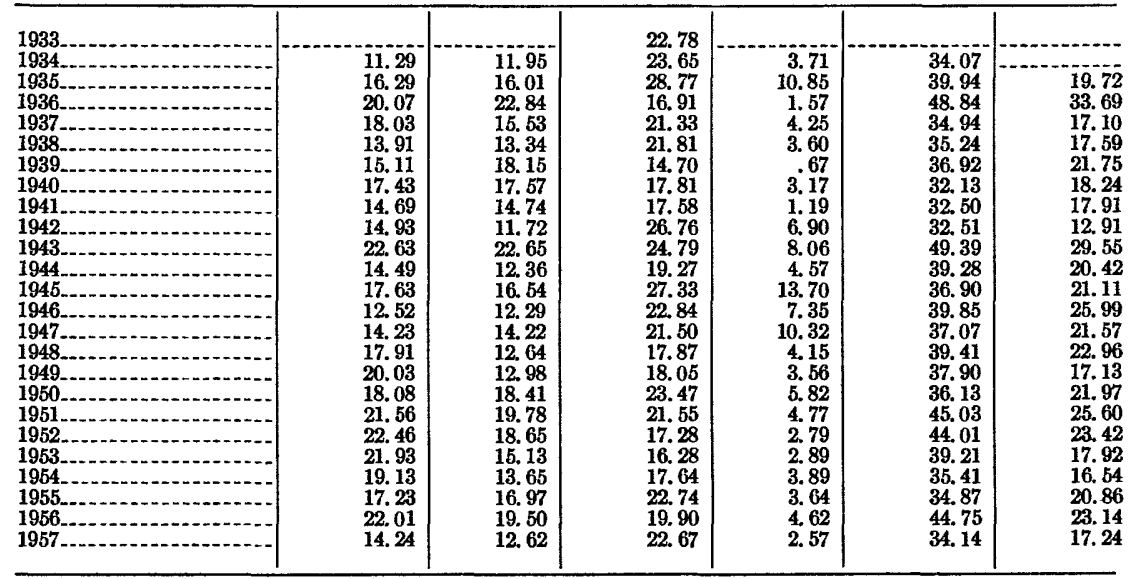

Shackham Brook area

\begin{tabular}{|c|c|c|c|c|c|c|}
\hline $\begin{array}{l}1933 \\
1934 \\
19356 \\
1937 \\
1938 \\
1940 \\
1941 \\
1943 \\
1945 \\
1946 \\
1948 \\
1949 \\
1950 \\
1951 \\
1952 \\
1953 \\
1954 \\
1955 \\
1956 \\
1957\end{array}$ & $\begin{array}{l}15.07 \\
19.57 \\
22.16 \\
21.68 \\
17.24 \\
16.87 \\
19.05 \\
18.93 \\
16.32 \\
24.28 \\
16.14 \\
20.82 \\
15.09 \\
17.69 \\
18.06 \\
19.44 \\
22.52 \\
25.53 \\
20.60 \\
22.51 \\
19.25 \\
22.63 \\
20.36 \\
14.45\end{array}$ & $\begin{array}{l}16.21 \\
17.98 \\
22.97 \\
25.01 \\
21.11 \\
20.67 \\
20.91 \\
19.30 \\
16.48 \\
27.41 \\
18.53 \\
19.72 \\
16.95 \\
21.17 \\
15.78 \\
17.65 \\
22.67 \\
23.02 \\
17.69 \\
16.54 \\
13.37 \\
17.69 \\
19.97 \\
14.47\end{array}$ & $\begin{array}{l}19.42 \\
16.06 \\
25.58 \\
18.83 \\
27.91 \\
20.58 \\
16.88 \\
21.92 \\
21.24 \\
24.68 \\
29.24 \\
21.54 \\
26.84 \\
27.38 \\
19.86 \\
18.08 \\
22.38 \\
18.70 \\
16.79 \\
21.63 \\
15.71 \\
13.79 \\
27.05 \\
15.17 \\
16.60\end{array}$ & $\begin{array}{r}1.58 \\
6.30 \\
2.73 \\
8.97 \\
5.67 \\
1.09 \\
7.82 \\
1.81 \\
5.63 \\
11.56 \\
5.25 \\
12.07 \\
10.67 \\
10.62 \\
5.08 \\
4.89 \\
3.74 \\
2.50 \\
5.55 \\
3.07 \\
3.02 \\
3.07 \\
4.39 \\
4.05\end{array}$ & $\begin{array}{l}34.49 \\
35.63 \\
47.74 \\
40.51 \\
45.15 \\
37.45 \\
35.93 \\
40.85 \\
37.56 \\
48.96 \\
45.38 \\
42.36 \\
41.93 \\
45.07 \\
37.92 \\
37.52 \\
44.90 \\
44.23 \\
37.39 \\
44.14 \\
34.96 \\
36.42 \\
47.41 \\
29.62\end{array}$ & $\begin{array}{l}18.56 \\
19.56 \\
29.27 \\
27.74 \\
30.08 \\
26.34 \\
22.00 \\
27.12 \\
18.29 \\
33.04 \\
30.09 \\
24.97 \\
29.02 \\
31.84 \\
26.40 \\
22.73 \\
27.56 \\
26.76 \\
20.19 \\
22.09 \\
16.44 \\
20.71 \\
23.04 \\
18.86\end{array}$ \\
\hline
\end{tabular}

1 Partly estimated. 


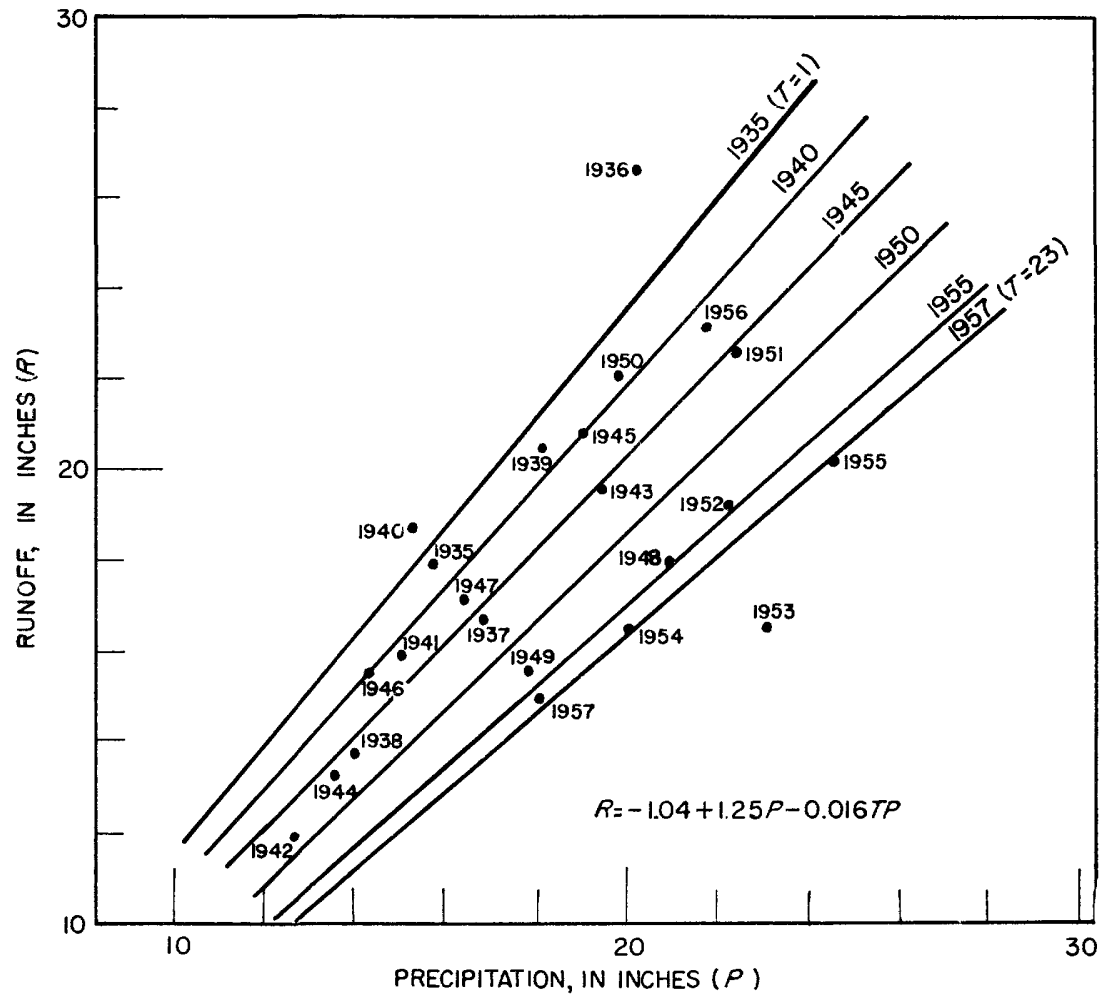

Figure 26. - Relation between runoff and precipitation in the Cold Spring Brook area for the 6-month period ending April 30, showing the change with time.

TABLE 8.-Relation of runoff to precipitation

\begin{tabular}{|c|c|c|c|c|}
\hline \multirow{2}{*}{ Station } & \multicolumn{2}{|c|}{ Period } & \multirow{2}{*}{$\begin{array}{l}\text { Years of } \\
\text { record }\end{array}$} & \multirow{2}{*}{ Regression equation } \\
\hline & Months & Ending- & & \\
\hline Sage Brook near South New Berlin... & $\begin{array}{r}6 \\
6 \\
12\end{array}$ & $\begin{array}{l}\text { Apr. } 30 \\
\text { Oct. } 31 \\
\text { Apr. } 30\end{array}$ & $\begin{array}{l}1934-57 \\
1934-57 \\
1935-57\end{array}$ & $\begin{array}{l}R=+1.21+0.97 P-0.010 T P \\
R=-9.34+0.68 P \\
R=-9.50+0.79 P\end{array}$ \\
\hline Cold Spring Brook at China...... & $\begin{array}{r}6 \\
6 \\
12\end{array}$ & $\begin{array}{ll}\text { Apr. } & 30 \\
\text { Oct. } & 31 \\
\text { Apr. } & 30\end{array}$ & $\begin{array}{l}1935-57 \\
1935-57 \\
1936-57\end{array}$ & $\begin{array}{l}R=-1.04+1.25 P-0.016 T P \\
R=-4.52+0.48 P \\
R=-1.39+0.63 P\end{array}$ \\
\hline Shackham Brook near Truxton.... & $\begin{array}{r}6 \\
6 \\
12\end{array}$ & $\begin{array}{l}\text { Apr. } 30 \\
\text { Oct. } 31 \\
\text { Apr. } 30\end{array}$ & $\begin{array}{l}1934-57 \\
1934-57 \\
1934-57\end{array}$ & $\begin{array}{l}R=+4.76+0.89 P-0.011 T P \\
R=-4.84+0.49 P \\
R=-4.96+0.73 P\end{array}$ \\
\hline Albright Creek at East Homer... & $\begin{array}{r}6 \\
6 \\
12\end{array}$ & $\begin{array}{l}\text { Apr. } 30 \\
\text { Oct. } 31 \\
\text { Apr. } 30\end{array}$ & $\begin{array}{l}1940-57 \\
1940-57 \\
1941-57\end{array}$ & $\begin{array}{l}R=+7.97+0.52 P \\
R=-8.98+0.64 P \\
R=-4.90+0.68 P\end{array}$ \\
\hline
\end{tabular}

The magnitudes of the indicated changes in the relation between precipitation and runoff were determined from the multiple-regression 
equations. The reductions in runoff between the initial year and the final year for the 6-month period ending April 30 are:

\begin{tabular}{|c|c|c|c|}
\hline$R e d \imath$ & $\begin{array}{l}\text { tion of runoff } \\
\text { Period of record used }\end{array}$ & $\begin{array}{l}\text { Total reduction } \\
\text { in runoff } \\
\text { (inches) }\end{array}$ & $\begin{array}{l}\text { Annual rate of } \\
\text { reduction } \\
\text { (inches per year) }\end{array}$ \\
\hline Sage Brook & $1934-57$ & 4. 18 & 0.17 \\
\hline Cold Spring Brook & $1935-57$ & 6. 76 & .29 \\
\hline Shackham Brook... & $1934-57$ & 5.13 & 21 \\
\hline Albright Creek & $1940-57$ & 0 & 0 \\
\hline
\end{tabular}

These indicated reductions are based on the mean precipitation for the period of record at each station.

\section{COVARIANCE ANAL YSIS}

The relation between runoff and precipitation also was studied by analysis of covariance between early and late periods of each station record. The analyses were made for the 6-month periods ending April 30 and October 31 and for the hydrologic year ending April 30. The analysis of covariance was used to determine if the relation between precipitation and runoff for the latter part of each station record differed from the relation for the earlier period.

The limitations imposed by grouping the data into early and late periods were recognized. The covariance analysis is best suited to the testing of groups of data, each of which is homogeneous. An abrupt change in the relation of the variables provides the ideal point for separating the data into groups. However, the data from the reforested areas cannot be grouped on the basis of abrupt change; gradual rather than abrupt changes in streamflow of the reforested areas were to be expected if these changes were related to the tree growth.

The chronological tabulation of precipitation and runoff data for each study area was divided into halves to obtain the early and late period of each record. Covariance between precipitation and runoff for the late period was compared with the covariance for the early period to determine changes in (a) the relation between means for the early and late periods, and (b) the relation between the regression slopes for early and late periods. Significance of indicated changes was determined by using the Fisher F-test in the manner described by Wilm (1944).

The analyses of covariance indicated significant changes in both means and regression slopes between early and late periods of record for the 6-month period ending April 30 for all 3 reforested areas. A significant change in regression slopes between early and late periods of the station record was also determined for the 6-month period ending October 31 for the Shackham Brook area. 


\section{RELATION BETWEEN RUNOFF FROM REFORESTED AREA AND FROM CONTROL AREA}

\section{SEASONAL AND ANNUAL RUNOFF}

Total runoff from the partly reforested watershed of Shackham Brook near Truxton was correlated with the total runoff from the specific control area of Albright Creek at East Homer and the year of occurrence, to determine changes in the runoff relation for the period of record 1941-57. The relation was studied for the same 3 hydrologic periods as the precipitation-runoff study; these are the seasonal 6-month periods ending April 30 and October 31, and the 12-month period ending April 30.

The model equations used in the precipitation-runoff study (equations 2-5 previously listed) were considered by substituting the Albright Creek runoff for precipitation in the equations. The model

$$
R_{S}=a+b_{1} R_{A}+b_{2} T R_{A}
$$

in which $R_{S}$ is the runoff in inches of Shackham Brook for a given hydrologic period, $R_{A}$ is the runoff in inches of Albright Creek for the same period, and $T$ is the position of the period in chronological sequence beginning with $T=1$ for the first year of record, gave best correlation of the data as determined from a comparison of the standard errors of estimate for each model considered. Regressions based on equation 8 were computed as follows:

\begin{tabular}{|c|c|c|c|}
\hline \multicolumn{4}{|c|}{ Computed regressions } \\
\hline Period & & & \\
\hline Months & Ending- & record & Regression equation \\
\hline $\begin{array}{l}6 \\
6 \\
12-1-1\end{array}$ & $\begin{array}{l}\text { Apr. } 30 \\
\text { Oct. } 31 \\
\text { Apr. } 30\end{array}$ & $\begin{array}{l}1941-57 \\
1940-57 \\
1941-57\end{array}$ & $\begin{array}{lll}R_{S}=+0.72+1.17 & R_{A}-0.015 \\
R_{S}=+0.43+1.11 & R_{A}=0.024 \\
R_{A} & T R_{A} \\
R_{S}=+3.33+1.03 & R_{A}-0.015 & T R_{A}\end{array}$ \\
\hline
\end{tabular}

The three relations are shown graphically in figures 27 to 29 .

Significance of a time trend in the relation between runoffs was determined in the manner previously described. Reductions in runoff of Shackham Brook were found significant at the 5-percent level for all 3 hydrologic periods. For the value of the mean runoff from Albright Creek for each hydrologic period, the reductions in total runoff from 1941 to 1957 from Shackham Brook as determined by the regression equations are as follows:

Computed reduction of runoff from Shackham Brook, 1941-57

\begin{tabular}{|c|c|c|c|}
\hline \multicolumn{2}{|c|}{ Period } & \multirow{2}{*}{$\begin{array}{c}\text { Total reduction } \\
\text { in runoff (inches) }\end{array}$} & \multirow{2}{*}{$\begin{array}{l}\text { Annual rate of } \\
\text { reduction in runoff } \\
\text { (inches per year) }\end{array}$} \\
\hline Months & Ending- & & \\
\hline 6 & $\begin{array}{ll}\text { Apr. } & 30 \\
\text { Oct. } & 31 \\
\text { Apr. } & 30\end{array}$ & $\begin{array}{l}4.78 \\
2.57 \\
6.05\end{array}$ & $\begin{array}{r}0.23 \\
.14 \\
.36\end{array}$ \\
\hline
\end{tabular}


Runoffs from Albright Creek and Shackham Brook also were studied by analyses of covariance in the same manner as used in the precipitation-runoff study. The analyses of covariance indicated significant reductions at the 5-percent level in the mean flow of Shackham Brook during the latter half of the record for both the 6and 12-month periods ending April 30. Results of the analysis of covariance for the 6-month period ending October 31 were inconclusive.

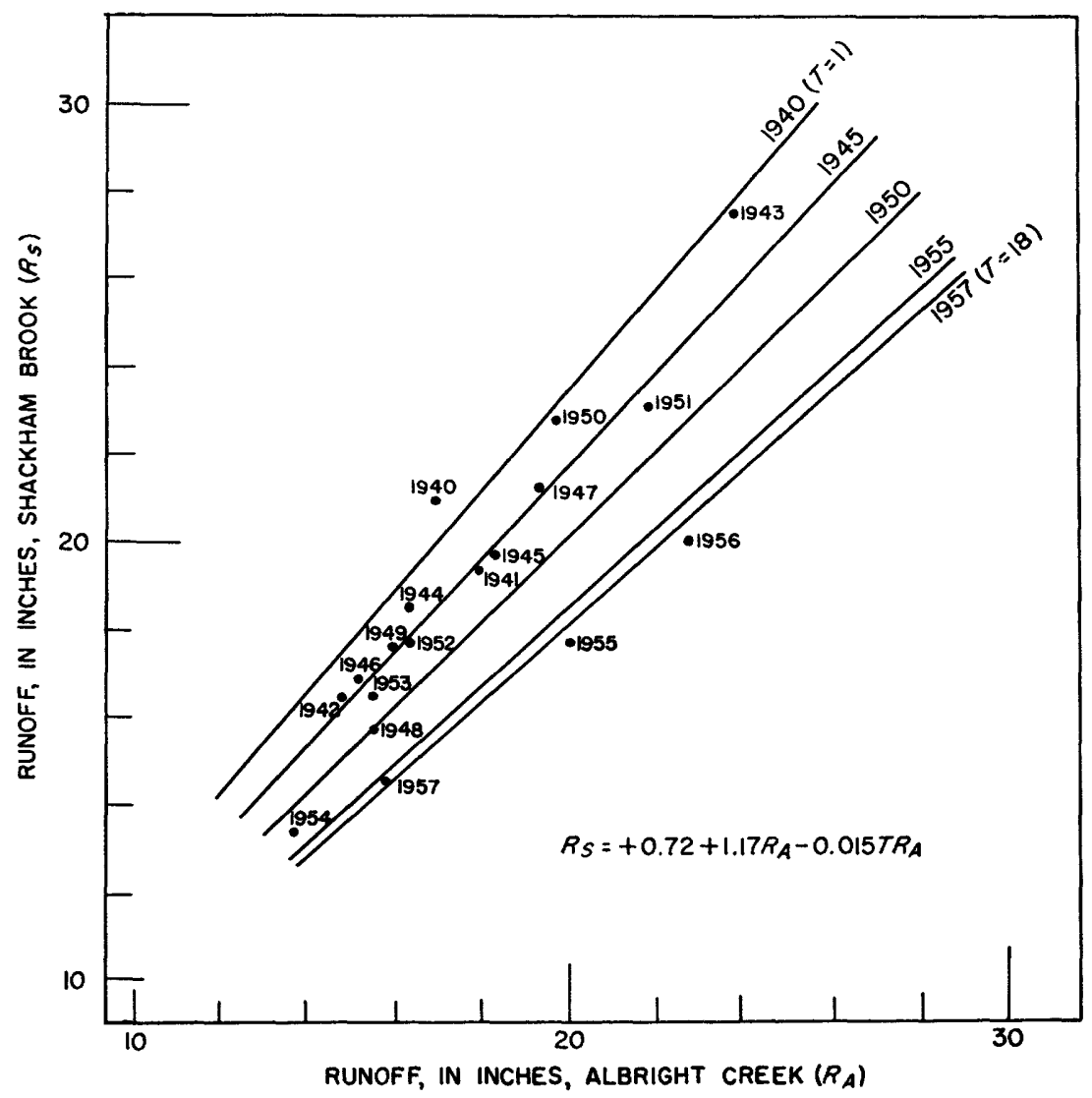

FIGURE 27.-Relation between runoff from Shackham Brook area and Albright Creek area for the 6-month period ending April 30, showing the change with time. 


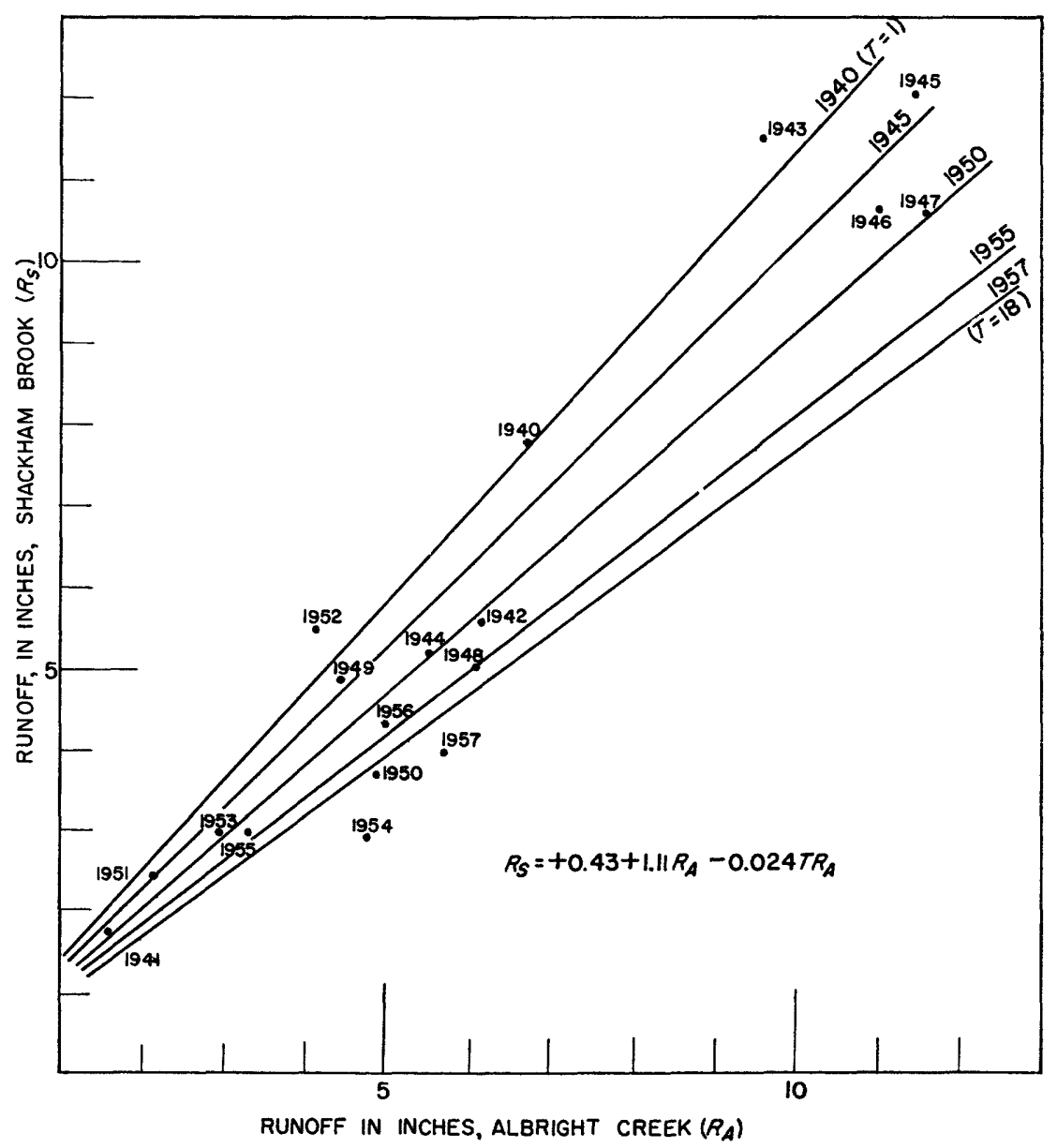

Fioore 28.-Relation between runoff from Shackham Brook area and Albright Creek area for the 6-month period ending October 31, showing the change with time. 


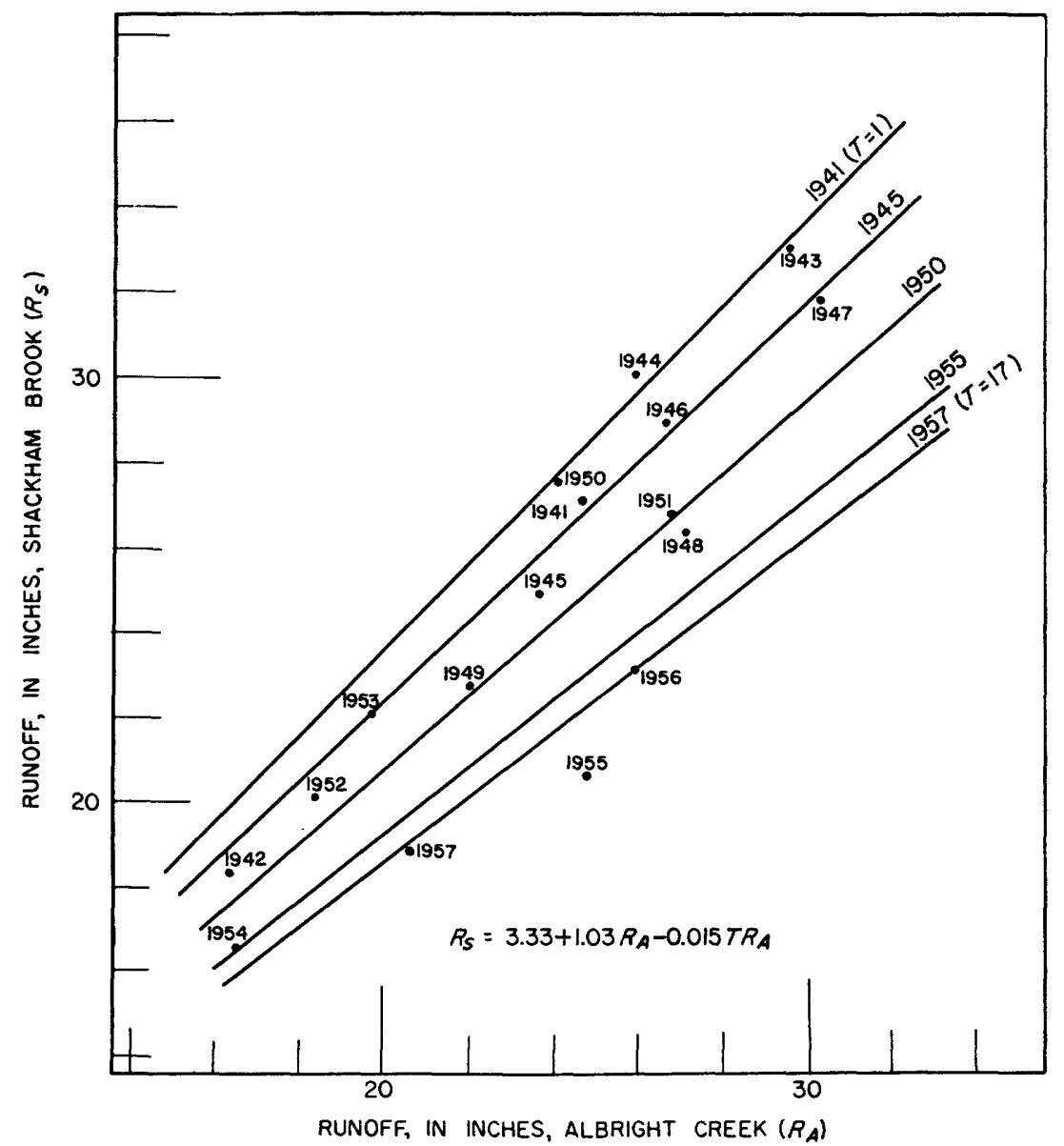

FIGURE 29.--Relation between runoff from Shackham Brook area and Albright Creek area for the 12-month period ending April 30, showing the change with time.

\section{PEAK DISCHARGES}

Peak discharges of the reforested area of Shackham Brook were correlated with the concurrent peak discharges of the control area, Albright Creek. The relation was studied for the 6-month periods ending April 30 and October 31. These periods were selected because (a) they approximate closely the dormant and growing seasons in central New York, and (b) the 6-month period ending April 30 represents the period in which snow accumulation and snowmelt have pronounced effects on peak discharges. All peak discharges above 10 cfs per square mile on Albright Creek during November through 
April and 2 cfs per square mile on Albright Creek during May through October were used in the study. The concurrent peak on Shackham Brook was identified as that peak resulting from the same meteorologic event which caused the peak on Albright Creek. The peak discharges selected for this study are listed in table 9.

TABLE 9.-Related peak discharges on Shackham Brook and on Albright Creek

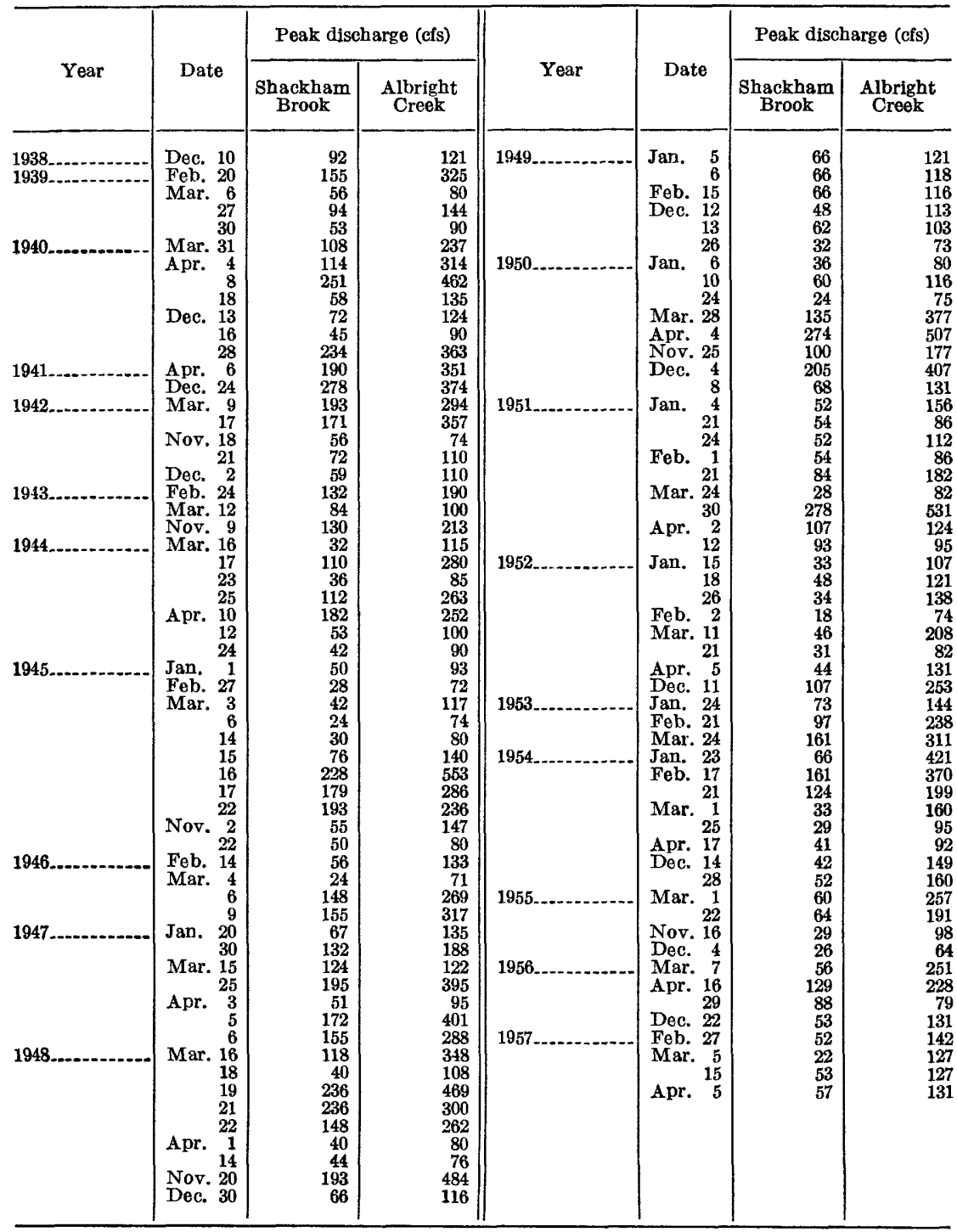


Multiple correction was made using the model equation

$$
\log S=a+b_{1} \log A+b_{2} T
$$

in which $S$ is the peak discharge of Shackham Brook, $A$ is the concurrent peak discharge of Albright Creek and $T$ is the period in a numerical sequence during which the peak occurred, beginning with $T=1$. The multiple regression for the 6-month period ending April 30 was based on 118 peaks between 1939 and 1957, and was computed as

$$
\log S=-0.133+0.977 \log A-0.012 T
$$

This relation is shown graphically in figure 30 .

The $b_{2}$ coefficient of -0.012 was tested for statistical significance in the manner previously described and was determined significant above the 1-percent level. A reduction in peak discharge of 41 percent is indicated for Shackham Brook; that is, for a peak discharge of a given magnitude on Albright Creek, the comparable peak discharge on Shackham Brook was 41 percent lower in 1957 than the comparable peak in 1939.

A multiple correlation using equation 9 also was made for the 6 -month period ending October 31. The regression based on 25 pairs of concurrent peak discharges was computed as

$$
\log S=-0.877+1.358 \log A-0.010 T
$$

The coefficient of $T$ was determined not significant at the 5-percent level, indicating that a change could not be statistically determined in the relation between peak discharges of Shackham Brook and Albright Creek for the period May 1 to October 31 .

The peak discharges occurring during the dormant season were further investigated to determine the existence of any internal seasonal trend during the period of record. To accomplish this, variables representing the seasonal trend were added to equation 9 to obtain

$$
\log S=a+b_{2} \log A+b_{3} T+b_{4} D+b_{5} T D
$$

in which $D$ is the position in a numerical sequence of the calendar date of the peak, ranging from 1 for November 1 to 183 for April 30 . The regression, based on the 118 pairs of concurrent peak discharges, was computed as

$$
\begin{gathered}
\log S=+0.012+0.986 \log A-0.028 T-0.00151 D \\
+0.000143 T D
\end{gathered}
$$

in which all coefficients were determined significant above the 1-percent level. The relation is shown graphically in figures 31 and 32. 


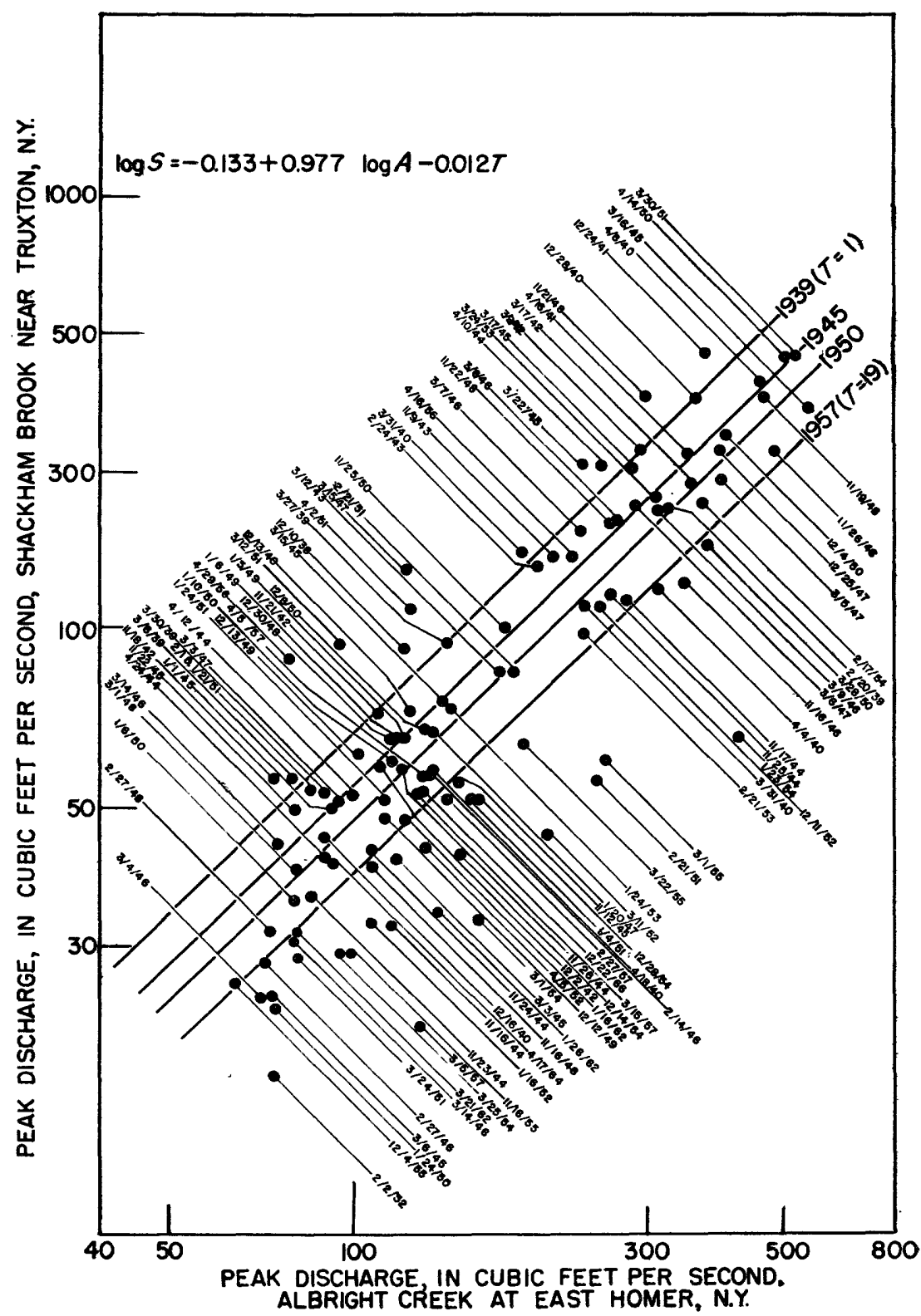

FIGURE 30.-Relation between peak flows of Shackham Brook and Albright Creek for the 6-month period ending April 30. 

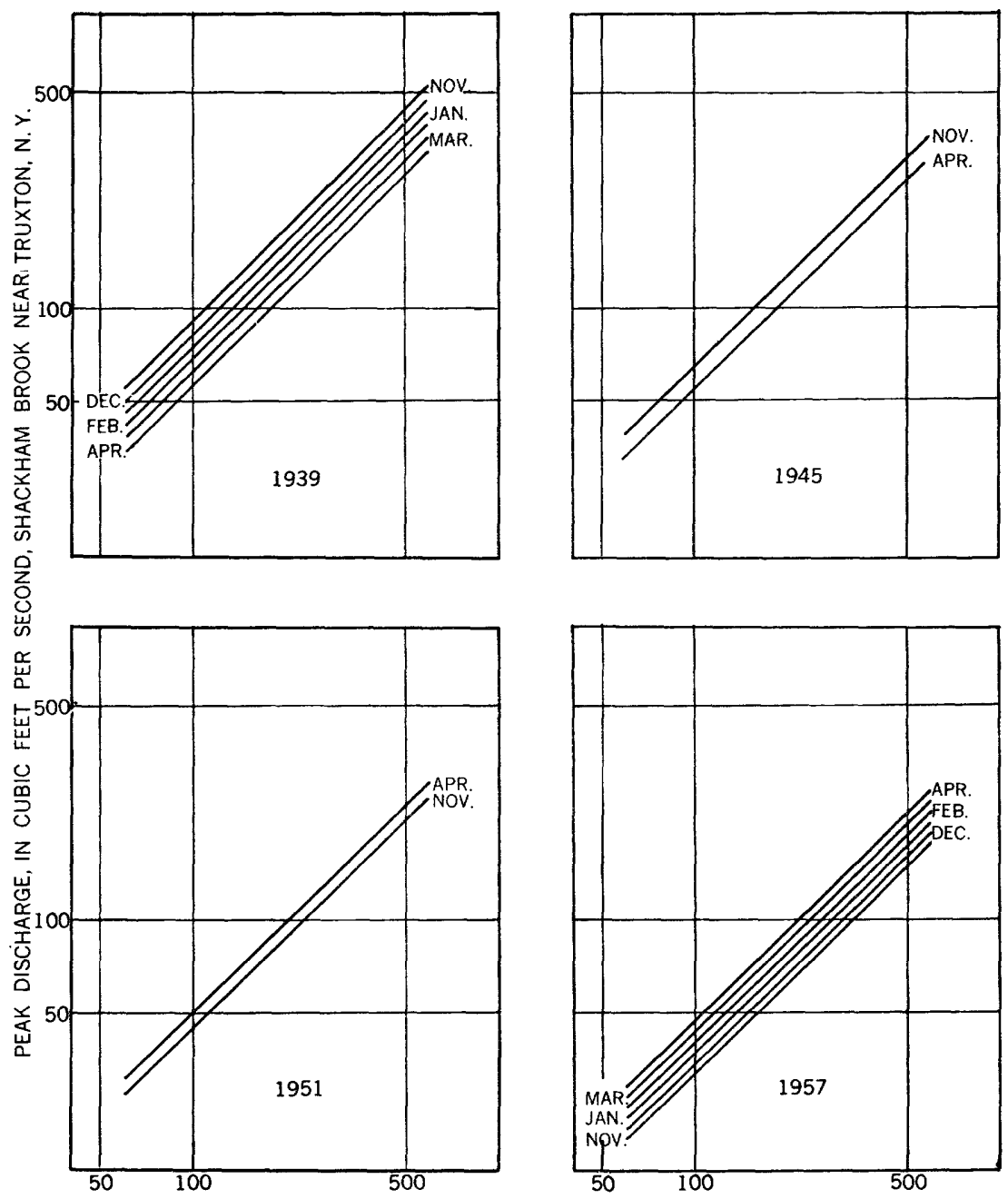

PEAK DISCHARGE, IN CUBIC FEET PER SECOND, ALBRIGHT CREEK AT EAST MOMER, N. Y.

FigURE 31.-Effect of data of occurrence on relation between peak discharges of Shackham Brook and Albright Creek. 

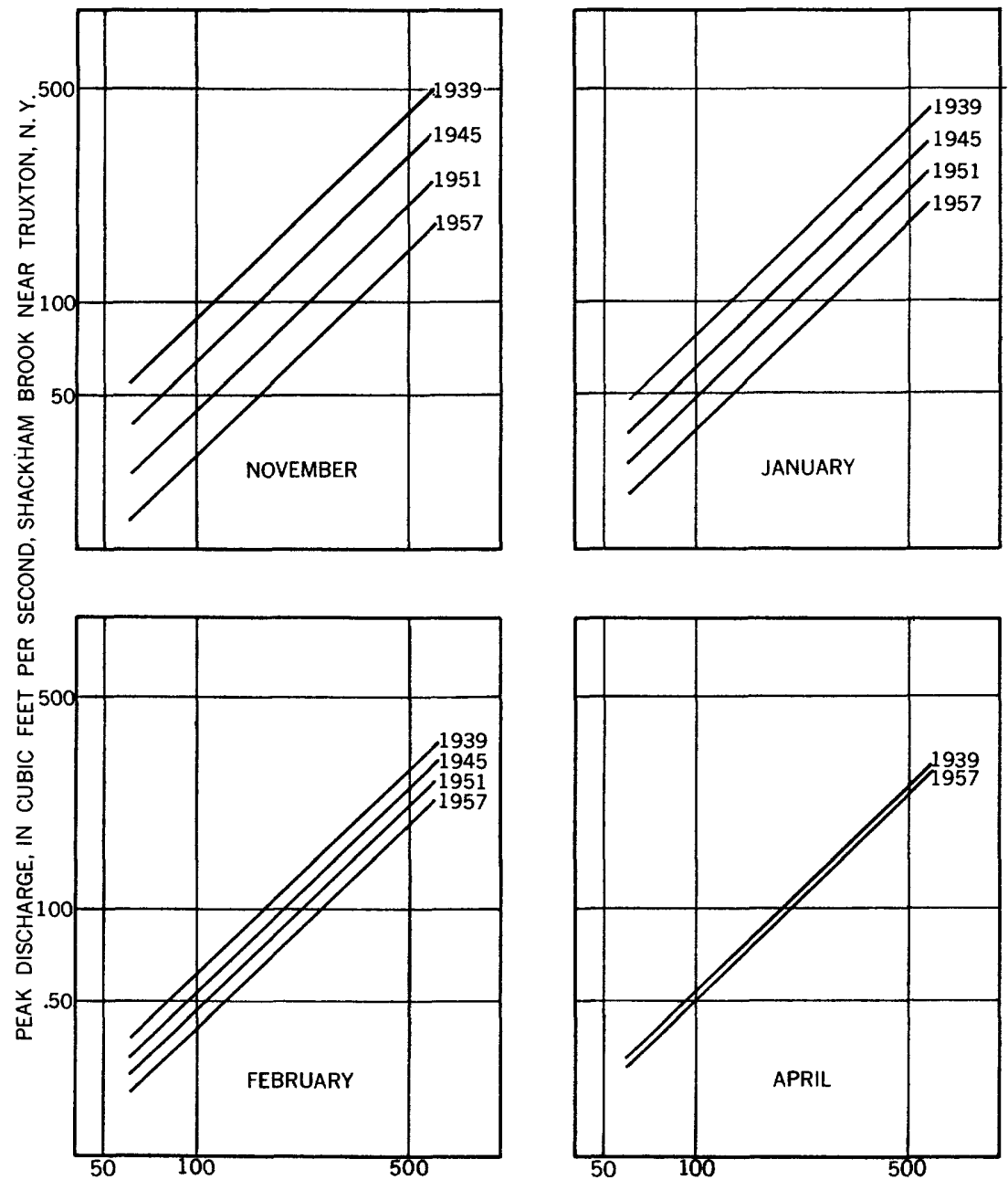

PEAK DISCHARGE, IN CUBIC FEET PER SECOND, ALBRIGHT CREEK AT EAST HOMER, N. Y.

Figure 32.-Effect of data of occurrence on relation between peak discharges of Shackham Brook and Albright Creek.

Analysis of the results shows that the reduction of peak discharges of Shackham Brook from 1934 to 1957 during the period November through April varies within the period as shown below:

Reduction of peak discharges from Shackham Brook, 1934-57

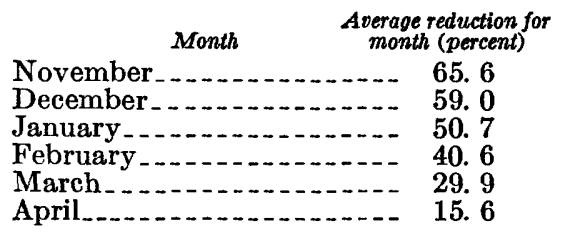


LOW FLows

The minimum daily flow of Shackham Brook in each hydrologic year ending April 30 was compared with that of Albright Creek for the same year. The minimum daily flows are shown in table 10 . Correlation was made using the model equation

$$
Q_{S}=a+b_{1} Q_{A}+b_{2} T
$$

in which $Q_{S}$ is the annual minimum daily flow of Shackham Brook near Truxton, $Q_{A}$ is the annual minimum daily flow of Albright Creek at East Homer, and $T$ is the position of the hydrologic year in a numerical sequence beginning with $T=1$.

The regression equation was computed as

$$
Q_{S}=+0.066+0.164 Q_{A}+0.0003 T
$$

in which the $b_{2}$ coefficient of +0.0003 was determined to be not significantly different from zero at the 5-percent level, indicating that no significant change had occurred in the low flows of Shackham Brook.

TABLE 10.-Annual low flows for Shackham Brook and Albright Creek areas

\begin{tabular}{l|r|r}
\hline & \multicolumn{2}{|c}{ Minimum daily flow (cfs) } \\
\hline & Sharkham Brook & Albright Creek \\
\hline 1939 & 0.075 & 0.085 \\
1940 & .096 & .186 \\
1941 & .098 & .09 \\
1942 & .19 \\
1943 & .104 & .37 \\
1944 & .144 \\
1945 & .088 & .41 \\
1947 & .212 & .50 \\
1948 & .131 & .86 \\
1949 & .138 & .45 \\
1950 & .092 & .168 \\
1951 & .074 & .26 \\
1953 & .121 & .180 \\
1954 & .110 & .170 \\
1955 & .120 & .110 \\
1956 & .042 & .030 \\
1957 & .006 & .27 \\
\hline
\end{tabular}




\section{OTHER ANALYSES}

\section{BASE-FLOW RECESSION}

Base-flow recession may be represented by the equation

$$
Q_{t}=Q_{0} e^{-k t},
$$

where $Q_{0}$ represents the initial discharge, $Q_{t}$ represents the discharge at $t$ days later, and $k$ is a physical constant. If $t$ is equal to 1 day, the equation becomes

where

$$
Q_{t}=K Q_{0},
$$

$$
K=e^{-k} \text {, }
$$

with $K$ representing the coefficient of recession, or the recession rate.

Base-flow recession rates, as defined by equation 17 , were determined for the three reforested areas and for the control area. For each station, data for the relations were obtained for the first 5-year period of record and for 1952-57 by determining the rates of discharge at the beginning and end of a calendar day.

Two distinct recession rates occurred during each year at all four stations. One rate occurred during the growing season; the other during the dormant season. A transition between the recession rates occurred in late April or early May and again in October or early November. Base-flow recession rates, therefore, were computed for growing and dormant seasons. A study of the dates of the transitional periods did not indicate any apparent trend or change in dates between the early and later years of record for any of the stations.

Base-flow recession relations were computed for the four stations using equation 17. These relations for Cold Spring Brook at China are shown graphically in figure 33 and the recession coefficients, $K$, for
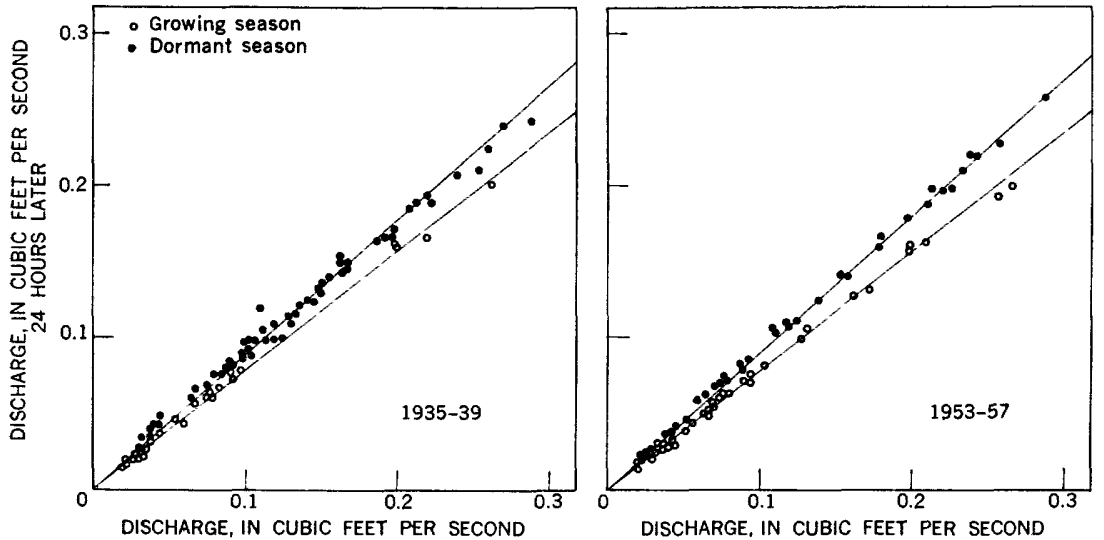

Figure 33.-Base-flow recession rates fol Cold Spring Brook at China. 
all computed relations are listed in table 11. Small changes in the recession rates between 5 -year periods for both growing and dormant seasons were tested for significance by analyses of covariance between the comparable groups of data. No significant changes between early and late periods were found at the 5-percent level for either season for any of the four areas.

TABLE 11.-Coefficients of base-flow recession

\begin{tabular}{|c|c|c|c|}
\hline Stream & Seasonal period & Years & $\begin{array}{l}\text { Recession } \\
\text { coefficient } \\
K\end{array}$ \\
\hline $\begin{array}{l}\text { Sage Brook near South New } \\
\text { Berlin. }\end{array}$ & 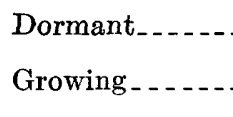 & $\begin{array}{l}1936-40 \\
1953-57 \\
1936-40 \\
1953-57\end{array}$ & $\begin{array}{r}0.903 \\
.903 \\
.825 \\
817\end{array}$ \\
\hline Cold Spring Brook at China_..... & Dormant._.... & $\begin{array}{l}1935-39 \\
1953-57 \\
1935-39\end{array}$ & $\begin{array}{l}.872 \\
.892 \\
.779 \\
705\end{array}$ \\
\hline Shackham Brook near Truxton... & $\begin{array}{l}\text { Dormant } \\
\text { Growing }\end{array}$ & $\begin{array}{l}1936-40 \\
1953-57 \\
1936-40 \\
1953-57\end{array}$ & $\begin{array}{r}919 \\
.924 \\
.871 \\
880\end{array}$ \\
\hline Albright Creek at East Homer... & 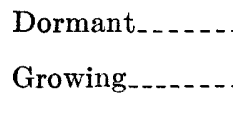 & $\begin{array}{l}1940-44 \\
1953-57 \\
1940-44 \\
1953-57\end{array}$ & $\begin{array}{l}.910 \\
.911 \\
.875 \\
.878\end{array}$ \\
\hline
\end{tabular}

\section{RELATION BETWEEN VOLUMES OF DIRECT RUNOFF AND PRECIPITATION FROM INDIVIDUAL STORMS}

Direct runoff is a residual of precipitation after the demands of interception and infiltration are met. Changes in these demands would affect the amount of direct runoff and the relation between precipitation and direct runoff. To test for a change, direct runoff was correlated with the storm precipitation which caused the direct runoff.

Direct runoff from each storm was determined from the hydrograph by subtracting the base flow from the total flow. The base flow was delineated by extending the hydrograph prior to the beginning of the direct runoff to the time of the peak discharge, and by extending backward the hydrograph subsequent to direct runoff to a point about 6 to 12 hours past the peak. The two recessions then were connected by a smooth transition.

Volumes of direct runoff were computed for the first 5-year period and for the water years 1952-57 for each study area. For each period, direct runoff was computed for all storms of more than one-half inch of precipitation and for a representative number of storms below onehalf inch of precipitation. However, no runoff periods were used in 
which either snowfall or snowmelt was a factor. An index based on the antecedent 30-day rainfall total was used to delineate the runoff potential of the storm as either high, average, or low. Other measures of antecedent rainfall were also considered, but graphical correlations indicated that the index based on the 30-day antecedent rainfall best described the runoff potential.

The data on runoff and storm precipitation were transformed logarithmically to approximate a linear relation within the range of data, and early and late periods were then tested for differences by analyses of covariance. No significant differences at the 5-percent level were detected between early and late periods in either means or slopes of the relations for any of the four stations. Results of this study are inconclusive because of the large scatter in the data.

The relation between storm precipitation and direct runoff is shown graphically in figure 34 .

\section{METHODS REJECTED}

Several other methods of hydrologic analysis were considered and rejected. The unit-hydrograph approach was rejected early in the study because the precipitation and runoff data, which were collected independently of each other, were not adequately synchronized for such a study. Flood frequency, low-flow frequency, and flow-duration techniques of analyses were also rejected because no rigorous statistical comparisons could be made of data arrayed in this manner. Comparisons by these techniques would be by visual means only, and therefore not conclusive. An attempt was made to improve the relation between peak flows for a 5-year period on Shackham Brook near Truxton with associated storm precipitation by including storm intensity. Graphical correlations showed no improvement. Grouping of the data into groups of high, average, and low potential, as in the study of volumes of direct runoff, also gave no appreciable improvement in the relation. The study therefore was not continued beyond this step. 


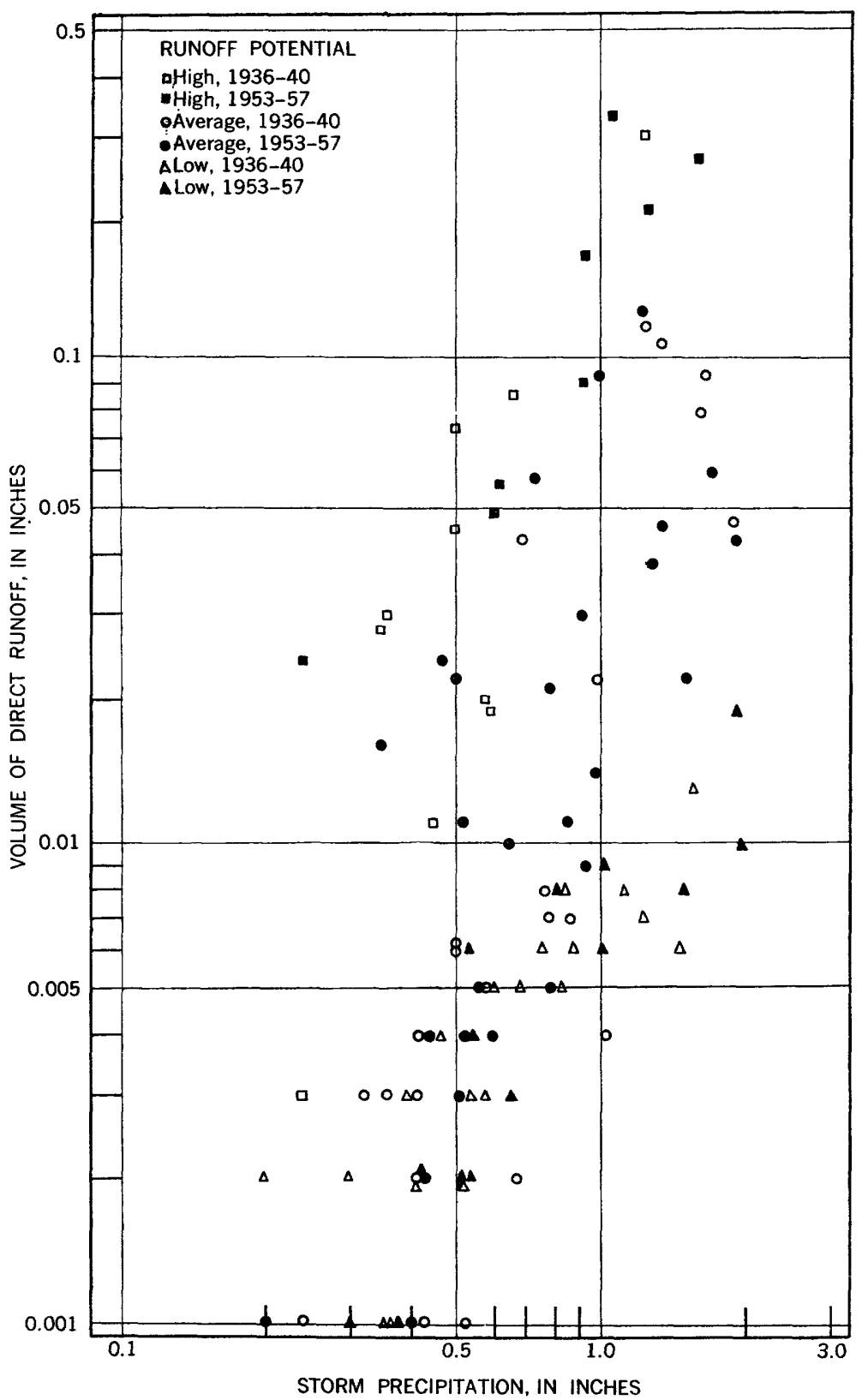

Figure 34.-Relation between storm precipitation and volumes of direct runoff for the Sage Brook area. 


\section{SUMMARY}

The statistical analyses indicate that certain definite changes have occurred in the streamflow of the three partly reforested areas between the time of reforestation and 1957. Based on correlations with precipitation, the following changes in runoff for the 6-month period ending April 30 are indicated:

Changes in runoff in partly reforested areas, 1934-57

\begin{tabular}{|c|c|c|c|}
\hline Area & $\begin{array}{c}\text { Total reduction } \\
\text { in runnoff } \\
\text { (inches) }\end{array}$ & $\begin{array}{c}\text { Annual rate of } \\
\text { reduction } \\
\text { (inches per year) }\end{array}$ & $\begin{array}{l}\text { Percent reduc- } \\
\text { tton for pertod } \\
\text { of record }\end{array}$ \\
\hline Pand & 4. 18 & 0.17 & 23 \\
\hline B Brook & $\begin{array}{l}\text { 6. } 76 \\
5.13\end{array}$ & $\begin{array}{r}.29 \\
21\end{array}$ & $\begin{array}{l}31 \\
23\end{array}$ \\
\hline
\end{tabular}

These changes are based upon the mean precipitation for the period of record of each area.

Correlation between the flows of Shackham Brook and its control, Albright Creek, indicate that the following reductions have occurred in the flows of Shackham Brook:

Reductions in flow, Shackham Brook, 1939-57

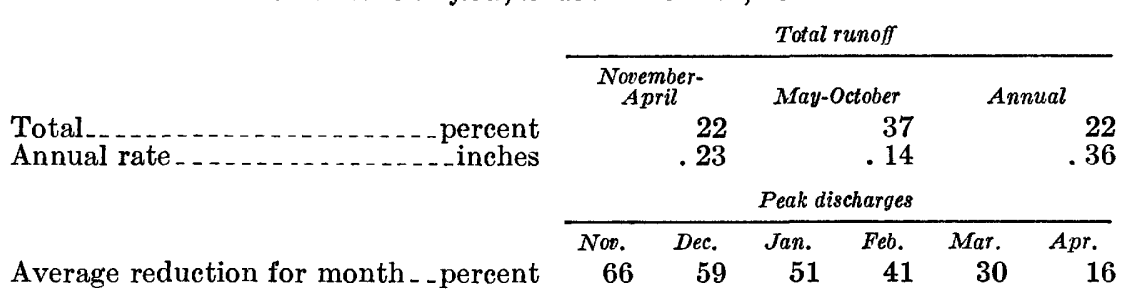

No significant changes with time were found in (a) the peak discharges of Shackham Brook for the period May 1 to October 31, based on correlation with peak discharges of Albright Creek; (b) base-flow recession rates for any of the four streams; (c) volumes of direct runoff, from correlation with storm precipitation; and (d) annual minimum daily flows of Shackham Brook near Truxton, based on correlation with annual minimum daily flows of Albright Creek at East Homer.

\section{EVALUATION OF THE STUDY}

The study of the effect of forests on streamflow in central New York is unique in that no abrupt treatment such as denudation was applied. The ecological conditions existing at the time of reforestation were virtually undisturbed except for the planting of coniferous trees. By planting the seedlings in grub-hoe slits, no grasses were removed and no areas of bare soil were exposed. In fact, care was taken to disturb the ground cover as little as possible in order that the newly planted seedlings might benefit from the shade afforded 
by the weeds and grasses during the process of becoming established.

Thus the major change since reforestation has been a gradual succession of the vegetation from brush and weeds to coniferous woodlands in parts of each of the reforested areas. The trees were permitted to grow undisturbed. As they grew, the usual changes in ground cover occurred. By 1957, the plant growth beneath the tree canopies had disappeared, and a litter of conifer needles had accumulated. Because no thinning or cutting of the conifers was done, the branches of the trees in many of the plantations intermingled as they grew and formed a tight crown cover. These changes were gradual. Therefore it is logical to expect that changes in streamflow resulting from the changes in plant cover also would be gradual. This premisethat changes in the streamflow would be gradual-formed a basic consideration in the selection of techniques of analysis used in this study.

It is recognized that a lack of shielding of the gages probably has caused an underregistering of the actual precipitation. The tendency of the gages to underregister may also be inferred from the fact that in many years, the runoff for the period November through April exceeded the measured precipitation for the same period. However, the measured precipitation does represent an index of the basin precipitation, and tests have shown these indexes to be consistent with the areal pattern of precipitation for central New York.

The consistency of the precipitation indexes for the study areas also indicates no appreciable effect of a rain shadow or change in exposure. Field observations of the gage locations in 1957 revealed no serious encroachment of the surrounding trees upon the cone of influence of any of the gages. The minor changes in location of Shackham Brook 2 and Albright Creek 1 gages made for the convenience of the observers did not change the general exposure of either gage. Furthermore, both gages agree well with the areal pattern of precipitation.

In studying the relation between precipitation and runoff, no effect of antecedent precipitation was found for any of the three hydrologic periods. An apparent explanation for this is found in the physical interpretation of the ground-water elevations. On April 30 each year, the ground-water elevation is at or near the ground surface throughout most of the four areas, and therefore on this date the ground-water reservoir has a relatively constant volume of storage at the beginning of each hydrologic year. This relatively stable volume of storage on April 30 of each year also accounts for the lack of effect of antecedent precipitation on the May through November hydrologic period. In a similar manner, the relatively depleted ground-water reservoir on October 31 of each year provides no appre- 
ciable carryover effect of antecedent precipitation on the 6-month period beginning November 1 .

The model equation used in the study of the relation between runoff and precipitation indicates that changes in this relation are related not only to time, but to the magnitude of the precipitation as well. This is understandable from consideration of such factors in the hydrologic cycle as evapotranspiration, interception, infiltration, and soil moisture. The total quantity of each of these factors in any year is dependent upon the total amount of water available for the process and thus ultimately upon the precipitation. Thus greater precipitation in any year would result in proportionally greater amounts of water for the hydrologic processes.

The reductions in runoff as determined from the statistical studies are remarkably consistent. For Shackham Brook near Truxton; the average reduction in runoff during the period of record for November through April was 0.21 inch per season based on the relation with precipitation and 0.23 inch per season based on the relation with runoff from the Albright Creek control area. Also for Shackham Brook near Truxton, average reductions of 0.23 and 0.14 inch per season were determined for the growing and dormant seasons respectively. For the hydrologic year, an average reduction of 0.36 inch per year was determined, as compared with 0.37 inch per year as determined from the two 6-month periods.

Reductions in runoff for the period November through April were found at all three reforested areas. The magnitude of reduction varied for each area, but this variation could not be related to any measure of the reforestation nor to the size of the basin. An apparent relation was found between the magnitude of the reduction and the stream density of the basin, but this relation had no physical meaning and therefore was rejected.

The decreases in total flows and in winter peak flows in the three experimental areas are attributed to the partial reforestation of the areas. Trees affect streamflow by intercepting rain and snow, changing infiltration capacity of the soil, retarding snowmelt in the wooded areas, and increasing transpiration.

Coniferous trees intercept an appreciable portion of precipitation. Horton (1919) has indicated that as much as 0.18 inches of a 1-inch rainfall may be intercepted by pine trees. This figure agrees with data reported by Johnson (1942) although Johnson reported about 30 -percent interception during the winter season when precipitation fell mostly as snow. Also, Mayr (1925) has stated that as little as 1 percent of a light snow might reach the ground in a dense plantation of young spruce. 
Interception of precipitation in the reforested areas undoubtedly increased as the trees grew. The increased interception probably accounts for the major part of the reduction in streamflow for the winter period, and for at least part of the reduction in runoff for the growing period. The changes in runoff in the growing season may also reflect changes in the infiltration capacities of the soils in the forest areas. Increased infiltration capacities of the forest soils would reduce direct runoff from a storm and thus provide more soil moisture for evapotranspiration.

Forest cover also has an effect on snowmelt. Wilm (1948) concluded from a review of past literature that forests tend to retard the melting rates of snow. More recently, Garstka and others (1958, p. 39-47) observed that the snow had disappeared from 97 percent of the area of a 42 -acre clearing while still covering 43 percent of the area of the surrounding forest. The retarding of snowmelt in the reforested parts of the Shackham Brook area, with its resulting desynchronization of snowmelt runoff, and increased interception of the precipitation undoubtedly account for the reduction of peak discharges on Shackham Brook. Similar reductions in peak discharges for Cold Spring Brook at China and Sage Brook near South New Berlin could not be shown because of a lack of specific control areas for correlation. However, it is reasonable to assume that a reduction in peak discharges also has taken place in these two areas.

The indicated reductions of peak discharges on Shackham Brook represent average figures. They do not indicate that all peaks in the latter years have been reduced. In fact, several peaks occurring during March and April in the latter years were relatively higher than comparable peaks during the earlier years. These peaks were of various magnitudes. The relative increase in a few peaks also can be attributed to the desynchronization of snowmelt runoff from the open and reforested areas, as the snowmelt that is retarded in the reforested areas on one peak may be available to supplement the direct runoff on a subsequent peak.

Although there have been many studies of the effect of forests on streamflow, three investigations stand out for their scientific approach and firm results. In one of the first comprehensive studies in the United States, Bates and Henry (1928) showed that removal of the forest cover of an area in the Rio Grande National Forest near Wagon Wheel Gap, Colorado, increased annual water yields by about 0.96 inches per year, or about 15 percent. Peak discharges also were increased by as much as 35 percent.

Hoyt and Troxell (1934) reported that complete destruction by fire of the forest cover in the Fish Creek basin in California resulted in an 
average annual increase of 1.55 inches, or 29 percent, and an increase of 0.19 inches, or 475 percent, for the summer months. The high percentage increase for the summer months results from the extremely small runoff from the area under the forested conditions. Hoyt and Troxell also indicated that peak discharges were increased, as well as the minimum daily flows in the summer periods.

The denudation of an experimental area in the Coweeta Experimental Forest, N.C., was reported by Hoover (1944) to have increased annual runoff by 17.29 inches in the first year following cutting of all brush and trees, and by 13.26 inches in the second year after some regrowth had occurred. Hoover also reported that no significant changes occurred in peak discharges; no direct runoff occurred either before or after treatment, and all runoff was controlled by groundwater conditions.

The results of the present study in central New York agree in general with those of the three studies discussed above: reforestation produced the opposite effect of deforestation or denudation. The transition from grasses to coniferous woodland has caused progressively larger changes in certain phases of streamflow as the size of the trees increased. It is logical to assume, however, that these changes will not increase indefinitely. At some phase in their development the trees in the reforested parcels in the three areas will exert maximum and perhaps relatively stable influence on the streamflow. There is no evidence from the studies that the change had approached or was approaching this maximum point by 1957 , nor can the available data be extrapolated to determine when this will occur. Perhaps some indication that the optimum point is approaching is found in the fact that the conifers now have almost complete crown closure.

\section{REFERENCES CITED}

Ayer, G. R., 1949, A progress report on an investigation on the influence on reforestation on streamflow in State forests in central New York: U.S. Geol. Survey open-file report, $185 \mathrm{p}$.

Bates, C. G., and Henry, A. J., 1928, Forest and streamflow experiment at Wagon Wheel Gap, Colorado: U.S. Weather Bur. Monthly Weather Rev., Supp. $30,79 \mathrm{p}$.

Ezekiel, Mordecai, 1941, Methods of correlation analysis: New York, John Wiley and Sons, $531 \mathrm{p}$.

Garstka, W. U., Love, L. D., Goodell, B. C., and Bertle, F. A., 1958, Factors affecting snowmelt and streamflow: U.S. Bur. Reclamation and U.S. Forest Service, $189 \mathrm{p}$.

Hoover, M. D., 1944, Effect of removal of forest vegetation on water yields: Am. Geophys. Union Trans., v. 25, p. 969-977.

Horton, R. E., 1919, Rainfall interception: U.S. Weather Bur. Monthly Weather Rev., v. 47, p. 603-623.

Hoyt, W. G., and Troxell, H. C., 1934, Forests and streamflow: Am. Soc. Civil Engineers Trans., v. 99, p. 1-30. 
Johnson, E. A., and Kovner, J. L., 1956, Effect on streamflow of cutting a forest understory: Forest Science, v. 2, p. 82-91.

Johnson, W. M., 1942, The interception of rain and snow by a forest of young ponderosa-pine: Am. Geophys. Union Trans., 23d Ann. Mtg., pt. 2, p. 566-570.

Marbut, C. F., 1935, Soils of the United States, Part 3 in Baker, O. E., editor, Atlas of American agriculture: Washington, D.C., U.S. Dept. Agriculture, $98 \mathrm{p}$.

Mayr, Heinrich, 1925, Waldbau auf naturgesetzlicher Grundlage: 2d. ed., Berlin, Verlag von Paul Parey, 568 p.

Outlaw, D. E., 1953, A geologic and hydrologic study of Shackham watershed, New York State: U.S. Geol. Survey open-file report.

Snedecor, G. W., 1946, Statistical methods: 4th ed., Ames, Iowa, Iowa State Coll. Press, 485 p.

U.S. Soil Conservation Service, 1920, Soil Survey of Chenango County, New York: Washington, D.C., U.S. Soil Conserv. Service, ser. 1918, 37 p.

- 1930, Soil Survey of Delaware County, New York: Washington, D.C., U.S. Soil Conserv. Service, ser. 1930, 31 p.

1953, Soil Survey of Tioga County, New York: Washington, D.C., U.S. Soil Conserv. Service, ser. 1939, no. 20, 133 p.

Wilm, H. G., 1943, Statistical control of hydrologic data from experimental watersheds: Am. Geophys. Union Trans., v. 24, p. 618-624.

1948, The influence of forest cover on snowmelt: Am. Geophys. Union Trans., v. 29, p. 547-557. 